\title{
New York Sons of Erin: Nativism, Identity, and the Importance of Irish Ethnicity in the Civil War Era
}

Abbi E. Smithmyer

West Virginia University, aes0049@mix.wvu.edu

Follow this and additional works at: https://researchrepository.wvu.edu/etd

\section{Recommended Citation}

Smithmyer, Abbi E., "New York Sons of Erin: Nativism, Identity, and the Importance of Irish Ethnicity in the Civil War Era" (2020). Graduate Theses, Dissertations, and Problem Reports. 7611.

https://researchrepository.wvu.edu/etd/7611

This Thesis is protected by copyright and/or related rights. It has been brought to you by the The Research Repository @ WVU with permission from the rights-holder(s). You are free to use this Thesis in any way that is permitted by the copyright and related rights legislation that applies to your use. For other uses you must obtain permission from the rights-holder(s) directly, unless additional rights are indicated by a Creative Commons license in the record and/ or on the work itself. This Thesis has been accepted for inclusion in WVU Graduate Theses, Dissertations, and Problem Reports collection by an authorized administrator of The Research Repository @ WVU. For more information, please contact researchrepository@mail.wvu.edu. 


\title{
New York Sons of Erin: Nativism, Identity, and the Importance of Irish Ethnicity in the Civil War Era
}

\author{
Abbi E. Smithmyer \\ Thesis submitted to the Eberly College of Arts and Sciences \\ at West Virginia University \\ in partial fulfillment of the requirements for the degree of \\ Master of Arts in History \\ Jason Phillips, Ph.D., Chair \\ Brian Luskey, Ph.D. \\ Jennifer Thornton, Ph.D. \\ Department of History \\ Morgantown, West Virginia \\ 2020
}

Keywords: Identity, Ethnicity, Irish, New York, Nativism Copyright 2020 Abbi E. Smithmyer 


\begin{abstract}
New York Sons of Erin: Nativism, Identity, and the Importance of Irish Ethnicity in the Civil War Era
\end{abstract}

\begin{abstract}
Abbi E. Smithmyer
Nineteenth-century Irish Americans were bound together by a shared ethnic identity that was shaped by a strong attachment to Ireland, a closeness enhanced by their devotion to the Catholic faith, and an American population that held a deep prejudice against the ethnic group. This was especially the case in New York, which had the largest population of Irish Americans in the United States during this time. While many Sons of Erin enlisted into New York regiments, their most famous unit was the Irish Brigade. Therefore, the actions and treatment of the Irish Brigade greatly influenced the way immigrant service in the Civil War is remembered. This was similarly the case for their family and friends on the home front in New York. These individuals united behind their loved ones fighting in the Union Army and showed their support for them through ethnic festivities and religious ties.

Through their service to the Union, Irish Americans in New York embraced their ethnicity and created a shared loyalty to one another that united the group amidst rampant nativism. This diasporic identity found in New York's Irish-American population was only reinforced and heightened by military service to the Union during the Civil War. Rather than relinquish their ethnic bonds and become "Americanized," their identity as workers, Democrats, soldiers, Americans, or as an ethnic group was prevalent throughout their lives. This fluidity of identities allowed the Irish in New York to push for greater rights while building their ethnic culture in America. Their hard-fought efforts led to the emergence of cultural diversity in the United States, which countered the Anglo-American Protestantism of the nineteenth century.
\end{abstract}




\section{Acknowledgments}

Academic writing is often portrayed as an individual endeavor, with the historian off alone in their ivory tower. This process has shown me that nothing is farther from the truth. Although I proudly submit this work on my own, it would not have been possible without the countless individuals who guided, encouraged, and assisted me. First and foremost, I cannot thank my advisor and committee chair Dr. Jason Phillips enough for his unfailing support. He always provided me with prompt and helpful feedback on every piece of this project. I find it truly unique to have such a wonderful advisor who left me in control of my thesis, but was always there to ask thought-provoking questions that enhanced, shaped, and strengthened my work. More than anything, however, his patience and reassurance through this new and challenging process was instrumental in helping me achieve my academic pursuits.

Similarly, the additional help of my committee members Dr. Brian Luskey and Dr. Jennifer Thornton has been extremely valuable. Without fail, they asked tough questions that made me reconsider and improve my work in ways that I could not have imagined. For their guidance throughout the research and writing process, I am forever grateful. Their support and guidance throughout this process and my time at West Virginia University was more than any student could ever ask for.

I must also extend gratitude to two of the most influential educators I have had the pleasure of crossing paths with. While I have always been interested in history, my high school history teacher Brad Pflugh ignited my interest and passion for the American Civil War. Starting with your classes and continuing with countless battlefield trips and war games, I have truly grown as a person and historian. Similarly, Dr. Thomas Pearcy at Slippery Rock University has always provided me with constant support and encouragement. His research and work helped 
ignite my interest to look at the Civil War Era through a social and cultural lens and recognize the stories of all individuals. Their constant mentorship and friendship is something I treasure greatly.

Most importantly, I wish to thank my family. My wonderful parents have always pushed and encouraged me to achieve more than I could ever imagine. You have made me stronger and more determined to see my dreams become reality. You both instilled in me the importance of hard work and perseverance. Your compassion and life lessons have made me the woman I am today, and for that I am forever grateful. But most importantly, you taught me to dream big and live life to the fullest. This project would not have been possible without your constant love, reassurance, and support. For that and so much more, I thank you. 


\section{Table of Contents}

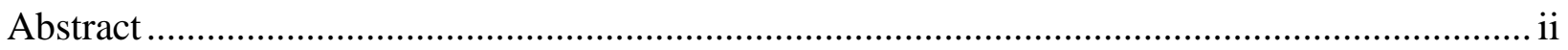

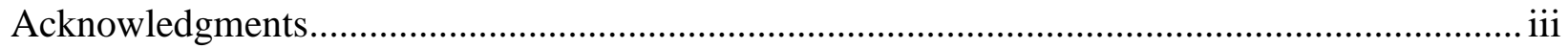

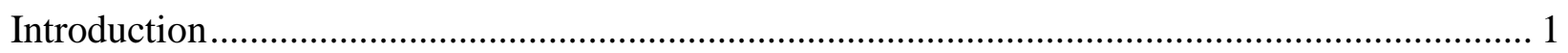

Chapter I: "We have always loved the flag of the Union:" Irish Americans, Know Nothing Politics, and Volunteering for the Union .......................................................................... 11

Chapter II: "Slaughtered like sheep:" Ethnicity, the Irish Brigade, and the Decline of Irish

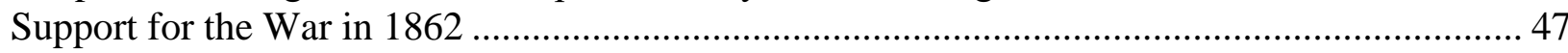

Chapter III: "The Irish spirit for the war is dead:" Tension on the Home Front, The Collapse of Irish Support, and its Impact on their Treatment in America ............................................... 84

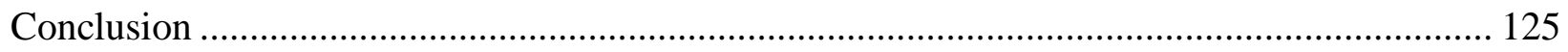

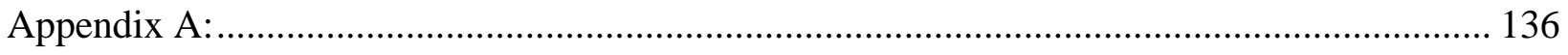

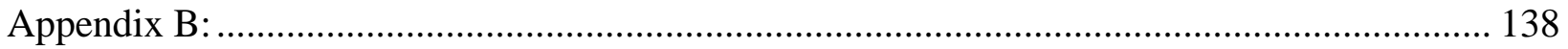

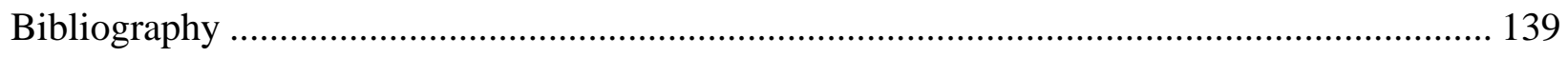




\section{Figure List}

Figure 1: 69th New York State Militia Prince of Wales Flag............................................... 44

Figure 2: 9th Massachusetts Infantry Regiment Recruitment Poster ..................................... 45

Figure 3: 69th Regiment New York State Militia Recruitment Poster ................................... 46

Figure 4: Irish Brigade Temperance Association Medal ................................................ 83

Figure 5: Corcoran's Irish Legion Recruitment Poster..................................................... 123

Figure 6: Harper's Weekly, "“Peace' Democracy on the Rampage” ..................................... 124

Figure 7: Harper's Weekly, “A 'Liberal' Surrender-Any Thing to Beat Grant”..................... 135 


\section{Introduction}

One week after the attack on Fort Sumter in Charleston, South Carolina, the New York Irish American, which was one of the Irish community's leading voices in the antebellum era, called for all "the adopted children of this glorious nation" to defend their new country. ${ }^{1}$ The newspaper's founder and editor Patrick Lynch, who left Ireland in 1847, wished for tensions between North and South to dissipate because "the despotic governments of the Old World" would "be able to boast that the grand experiment of man's capacity for self-government has come to naught." Despite this hope tensions reached a breaking point, leaving Lynch to use his paper to proclaim the duty of all Irish Americans in the United States to defend their adopted country. "Irish-Americans, we call on you by the sacred memories of the past, by your remembrance of the succor extended to your suffering brethren, by the future hope of your native land here taking root and springing toward a vigorous maturity," wrote the newspaper, "to be true to the land of your adoption in this crisis of her fate."

The Irish-American community responded to the newspaper's call to arms, with over 150,000 Irishmen filling the ranks of the Union Army by war's end. While most of them served in non-ethnic units, a significant portion chose to volunteer with their fellow Irishmen in regiments made up predominately of Irish Catholics. These ethnic units emerged throughout the North and included regiments such as the 23rd Illinois and the 9th Connecticut, however the state to raise the most Irish units was New York. On the eve of the Civil War, Irish-born individuals

\footnotetext{
${ }^{1}$ Cian T. McMahon, The Global Dimensions of Irish Identity: Race, Nation, and the Popular Press, 1840-1880 (Chapel Hill: University of North Carolina Press, 2015), 83.

${ }^{2}$ Irish American, April 20, 1861.
} 
made up twenty-five percent of New York's population, which made the state home to the largest Irish enclave in America. ${ }^{3}$

Ethnic identity played an important part in the lives of Irish Americans in the Civil War Era. As historian Don Yoder has explained, "ethnic consciousness, or ethnic identity" is "an attitude toward oneself and one's cultural world, which is shaped in individuals and eventually in groups through contact with other self-conscious groups of human beings with whom one comes into regular contact." "This definition applies to Irish Americans and is key to understanding how the ethnic group saw themselves and understood their service to America during the Civil War. Yet, individuals possess multiple identities that are constructed and fluid. Irish Americans in the nineteenth century possessed a range, or hierarchy of identities that was not set in stone. At different points throughout their life, and in the face of different events, certain identities were more prominent than others. Often, their ethnic identity loomed largest, however, this was not always the case. Sometimes their identity as soldiers, Democrats, workers, or Americans was more important, and understanding this ultimately deepens our understanding of Irish-American experiences during the Civil War Era. ${ }^{5}$ Even though nineteenth-century Irish Americans were bound together by a shared ethnic identity that was shaped by a strong attachment to Ireland, a closeness enhanced by their devotion to the Catholic faith, and an American population that held a deep prejudice against the ethnic group, antebellum experiences of the Irish in New York caused them to encounter the Civil War differently than Irish Americans elsewhere.

\footnotetext{
${ }^{3}$ Ira Rosenwaike, Population History of New York City (Syracuse, NY: Syracuse University Press, 1972 ), 41.

${ }^{4}$ Don Yoder, "The Pennsylvania Germans: Three Centuries of Identity Crisis," in America and the Germans: An Assessment of a Three-Hundred-Year History, ed. by Frank and Joseph McVeigh (2 vols.; Philadelphia: University of Pennsylvania Press, 1985), 1:42.

5 See Rogers Brubaker and Frederick Cooper, "Beyond 'Identity,"” in Theory and Society 29, no. 1 (February 2000): 1-47.
} 
Many sons of Erin living in New York rushed to join the Union ranks, enlisting in largely ethnic regiments like the 37th or the 166th New York Infantry. However, the most famous Irish unit of the Civil War was the Irish Brigade, which was comprised of three core New York infantry regiments: the 63rd, 69th, and 88th. Even though regiments made up of Irishmen from other states joined the Brigade at various times, the New York regiments made up the heart of the unit throughout the entirety of the war. ${ }^{6}$ As the most famous and visible example of Irish service in the Northern armies, the Irish Brigade's actions and treatment throughout the Civil War played a critical role on ethnic morale and identity. The Irish Brigade's actions throughout the conflict captivated the native-born and the Irish-American public already enthralled by war and soon became one of the most famous units in United States service. The brigade has garnered an unmatched following within the memory of ethnic service, largely due to their leadership by famed Irish nationalist Thomas Francis Meagher. The soldiers who fought under Meagher quickly earned renown for their ferocity and resilience in battle. Over the course of the war, only three Federal units sustained higher casualty rates than the Irish Brigade, and their devotion and sacrifice has played a vital role in how Americans understand the contributions made by Irish soldiers in the Civil War. By looking at the actions and reactions to the Irish

\footnotetext{
${ }^{6}$ The almost entirely non-Irish 29th Massachusetts Infantry joined the brigade in the spring of 1862 before being replaced by the largely Irish 28th Massachusetts in November. The 116th Pennsylvania Infantry, which was roughly half Irish and therefore never carried the green flag of Erin, also joined the Irish Brigade. The Irish 28th Massachusetts Infantry was initially meant to reinforce the Irish Brigade and not the 29th. However, the 28th Massachusetts was mustered up to strength sooner and was dispatched to serve under General Benjamin Butler in the Carolinas, which left the native-born, Protestant 29th Massachusetts to join the Irish Brigade instead. See, Thomas Wentworth Higginson, Massachusetts in the Army and Navy During the War of 1861-1865 (2 vols.; Boston: Wright \& Potter, 1895-1896), 1:248; William H. Osborne, The History of the Twenty-ninth Regiment of Massachusetts Volunteer Infantry in the Late War of the Rebellion (Boston: A. J. Wright, 1877), 142; William L. Burton, Melting Pot Soldiers: The Union's Ethnic Regiments (New York: Fordham University Press, 1998), 120-24, 149-150.
} 
Brigade, one can see how Irish Americans in the Civil War Era understood their ethnic identity, reacted to nativism, and became a more united group throughout the conflict. ${ }^{7}$

Even as the Irish Brigade garnered fame and success on the battlefield, their performance was sometimes overshadowed by the actions of their Irish community on the home front. Just as the Irish Brigade was the most famous ethnic unit during the war, the actions of the Irish in New York played a critical role on how native-born Americans understood immigrant contributions to the Northern war effort. Like their native-born neighbors, Irish-American men and women did everything they could to support the Union at the start of the conflict. However, as time went on and casualty counts continued to increase, Irish Americans at home and in the field began to question whether supporting the Union was really in their best interest. While Irish disillusionment has almost entirely been linked to the passage of the Emancipation Proclamation and the 1862 Battle of Fredericksburg, an examination of wartime accounts shows that perceived prejudice affected how the ethnic group understood their service to the Union. The fear of nativism at work was at the core of Irish worry, which in turn brought the group closer to one another and created a strong bond that was linked to their ethnic consciousness. Throughout the Civil War, even amidst nativist prejudice, Irish Americans in New York embraced their Irish ethnicity and created a tenacious loyalty to one another that unified the group through their service to the United States.

While many scholars have argued that service to the United States "Americanized" Irish soldiers during the Civil War Era, this study will show that wartime experiences underlined nativist prejudice and often segregated Irish recruits into distinct units that reinforced and often strengthened their ethnicity. The Irish in New York were also hard pressed to relinquish their

\footnotetext{
${ }^{7}$ William F. Fox, Regimental Losses in the American Civil War (Albany, NY: Albany Publishing, 1889); For an excellent summary on the costly service of the Irish Brigade, see David Power Conyngham, The Irish Brigade and its Campaigns (Glasgow: R \& T Washbourne, 1866).
} 
ethnic ties and throughout the conflict they looked to their Irish heritage to understand and support their ethnic community. This devotion to ethnicity created a powerful bond among the New York Irish that was seen both on the battlefield and the home front. Through their support for the Union, Irish Americans expressed their ethnic consciousness, even in the midst of rampant nativism.

The most significant questions facing scholars of the Irish in the Civil War revolve around Irish-American ethnic identity, its compatibility with the Union war effort, and how native-born Americans reacted to that identity during the conflict. An assimilationist narrative has often been used to understand how the Civil War affected the Irish in America. Historian Ella Lonn was the first to propose this idea when she claimed that "the word 'Americanization' was probably not in common usage by 1865 , and yet that process is exactly what happened." ${ }^{8}$ By focusing on the experiences of Irish Americans in the decades preceding the Civil War, historian Noel Ignatiev made a similar claim. In How the Irish Became White, Ignatiev seeks to uncover how "the Catholic Irish, an oppressed race in Ireland, became part of an oppressing race in America." In this work, he claims that the Irish chose to become members of the American white class by relinquishing much of their ethnic identity. Although little time is spent on the ethnic group's service in the Civil War he does assert that Irishmen "took up arms for the White Republic, and their place in it" by fighting for the Union. ${ }^{9}$

Recent historians have abided to this melting pot image, however this constrains and limits our understanding of Irish soldiers' service in the Civil War and does not adequately define Irish actions in the conflict. Historians William Burton and Christian Samito have demonstrated that like Anglo Americans, Irish Americans volunteered to serve the Union for a

\footnotetext{
${ }^{8}$ Ella Lonn, Foreigners in the Union Army and Navy (Baton Rouge: Louisiana State University Press, 1951 ), 660.

${ }^{9}$ Noel Ignatiev, How the Irish Became White (New York: Routledge, 1995), 1, 89.
} 
variety of reasons. Similar to Lonn, Burton argues "the typical immigrant held stronger loyalties than ethnicity. ${ }^{" 10}$ Likewise, Samito argues Irish Americans fought for the Union to help undermine nativist sentiment and demand equality in the United States by claiming that "loyalty trumped ethnicity." ${ }^{11}$ Like Ignatiev, both Burton and Samito also agree that that Irishmen felt they needed to prove their loyalty and repay America through service to the Union. However, this motivation is rarely found in material written during the conflict and is much more evident in the postwar writings of Irish veterans.

In the years after the fighting ended, Irish Americans worked to preserve their place within the historical narrative through the publication of regimental histories and soldiers memoirs. Rather than focus on their disillusionment and frustrations during the war, these postwar accounts highlighted the patriotism and devotion of Irish Americans for the Union. The first of these was David Power Conyngham's The Irish Brigade and Its Campaigns. This work presents the history of the unit, of which he was a staff officer for, and used the work to celebrate Irish service in the Civil War. ${ }^{12}$ Other soldiers of the Irish Brigade wrote of their patriotism and loyalty to America in the postwar years. These include William McCarter's My Life in the Irish Brigade and Peter Welsh's Irish Green and Union Blue. McCarter explained that he joined the unit to demonstrate his "love for my whole adopted country, not the North, nor the South, but the Union, one and inseparable..." ${ }^{13}$ Similar claims are made by Irish Brigade chaplain, Reverend William Corby in his postwar work, Memoirs of Chaplain Life: Three Years with the Irish

\footnotetext{
${ }^{10}$ Burton, Melting Pot Soldiers, 227.

${ }^{11}$ Christian G. Samito, Becoming American Under Fire: Irish Americans, African Americans, and the Politics of Citizenship during the Civil War Era (Ithaca, NY: Cornell University Press, 2009), 5.

${ }^{12}$ Conyngham, The Irish Brigade and its Campaigns.

${ }^{13}$ William McCarter, My Life in the Irish Brigade: The Civil War Memoirs of Private William McCarter, 116th

Pennsylvania Infantry, Kevin O’Brien, ed. (Cambridge, MA: De Capo Press, 1996), 221.
} 
Brigade in the Army of the Potomac. ${ }^{14}$ While their Irish heritage remained important to these men in the postwar years, they also played a role in shaping American identity during this time as well.

Historian Susannah Ural was one of the first historians to notice this postwar narrative and used it to challenge the assimilationist rhetoric presented by previous scholars who studied ethnic service. In her work The Harp and the Eagle, Ural focuses on Irish motivation for the war, while also arguing that Catholic Irish Americans possessed "an identity that was both Irish and American." ${ }^{15}$ She acknowledges Irish support for the war initially, but shows that as American loyalties diverged from theirs, Irish support waned. Ural argues that the draft riots in New York were not explosions of Irish disloyalty, but rather demonstrations of Irish frustration with a war that forced them to choose between their Irishness and their adopted country's Unionism. By the end of the Civil War, Ural shows the Irish had lost the credit they earned by their service because Anglo Americans failed to acknowledge their sacrifices. Although the most comprehensive study on Irish service to the Civil War, religion is not a prominent feature in her book. Catholicism separated the Irish from most other Union troops and greatly impacted their experiences on the battlefield and the home front. Similarly, Ural covers Irish experiences throughout the North, which leads to broad comparisons of the ethnic group as a whole.

In an attempt to detail the different ways Irish Americans across the North experienced the war differently, historian Ryan Keating looks at three different ethnic communities. In his book Shades of Green: Irish Regiments, American Soldiers, and Local Communities in the Civil War Era, Keating shows that in Illinois, Connecticut, and Wisconsin, native-born Americans

\footnotetext{
${ }^{14}$ William Corby, Memoirs of Chaplain Life: Three Years with the Irish Brigade in the Army of the Potomac, Lawrence Frederick Kohl, ed. (Chicago: La Monte, O'Donnell Printers, 1893).

${ }^{15}$ Susannah Ural Bruce, The Harp and the Eagle: Irish-American Volunteers and the Union Army, 1861-1865 (New York: New York University Press, 2006), 262.
} 
often assisted their Irish-American neighbors to ward off nativist sentiment, particularly after the New York City draft riots. He attributes this response to local Irish support for the Union and the way these smaller ethnic communities interacted with their native-born neighbors. This work demonstrates that Irish experiences during the Civil War Era were not the same across the North. Keating also points to the fact that the Irish communities he studied often arrived to the United States years before the outbreak of war, which allowed them to become better acquainted and a part of the communities they settled in.

This work seeks to build off of previous historians by discussing how Irish American men and women from New York understood and experienced the Civil War through an ethnic lens. It will also show that Irish soldiers held a multiplicity of identities, with certain identities becoming more prominent at different points throughout their life. This work will also demonstrate how contested ethnic identity was during the Civil War Era, with Irish people defining themselves differently than non-Irish people. Chapter One provides a detailed look at the nativist tendencies among Anglo Americans in the antebellum period and how this affected the experiences, expectations, and motivations of Irish Americans in New York at the start of the Civil War. Due to nativist prejudice, Irish soldiers and civilians united behind their ethnic identity on both the battlefield and the home front. Chapter Two will examine the pivotal military and political events of late 1862 and early 1863 and how it affected Irish Americans. These events include the Antietam Campaign, the removal of General George B. McClellan, the Emancipation Proclamation, and the Fredericksburg Campaign. A detailed explanation will be given to show how these events led to a reversal in Irish support for the war, which led many New York Irish to rally behind the Irish Brigade and further embrace their ethnic identity. The third and final chapter will follow the experiences of the New York Irish on the battlefield and 
the home front through the final years of the Civil War. Through ethnic bonds, Irish Americans were able to forge a tightknit community in New York that allowed them to progress in the postwar period despite a continuation of nativist attacks.

Although all soldiers collectively shared many things — such as drill, the drudgery of camp life, illness, hunger, battle, and homesickness - ethnicity was essential to how Irish soldiers reacted to and experienced the conflict. Through their recruitment into regiments made up almost entirely of Irishmen, performing daily tasks among comrades who shared similar backgrounds, taking part in Catholic traditions, and routinely hearing news about their Irish family and friends in the United States and abroad, Irish soldiers experienced the Civil War differently than their native-born counterparts. New York Irish soldiers in both ethnic and regular regiments encountered nativism throughout the course of the war, which not only reinforced their differences from Anglo Americans but also brought them closer together as an ethnic group.

This was similarly the case for their family and friends on the home front. Irish Americans in New York united behind their loved ones fighting in the Union Army and showed their support for them through ethnic festivities and celebrations. Irishwomen were instrumental in fundraising efforts that were centered on their ethnic and religious ties. Even as Irishmen joined regiments to support their adopted country and Irishwomen worked tirelessly to show their devotion to America on the home front, transatlantic ties to Ireland remained central to their ethnic identity in the United States. In some instances, support and assistance to those remaining in Ireland outweighed Irish American devotion to the Union. This fact only intensified as nativist prejudice continued to follow Irish Americans, even as thousands of ethnic soldiers died fighting for the Union. 
Irish Americans in New York made this point particularly evident. Because New York City was the entrance point for so many destitute Irish in the years before the Civil War, their ties to America were not well engrained. Nativist attacks and the rise and fall of the American or Know-Nothing Party only delayed their willingness to relinquish their ethnic ties. Irish experiences during the Civil War and the treatment of the Irish Brigade only conflicted this issue and caused many of the Irish in New York to become more aware of their ethnic bonds. Rather than become "Americanized" through service in the Civil War, a multigenerational group that possessed an "identity that was both Irish and American" as historian Susannah Ural has shown, emerged. Thus, this diasporic identity found in New York's Irish-American population, was only reinforced and heightened by military service to the Union during the Civil War. 


\section{Chapter I}

"We have always loved the flag of the Union:" Irish Americans, Know Nothing Politics, and Volunteering for the Union

The importance of Union service in the American Civil War for Irish soldiers has its roots in the antebellum period. The history of Irish Americans in the pre-war years and the reaction of Anglo Americans to the ethnic group is a complex story that is critical to understand. The sociopolitical movement called the American or Know Nothing Party, which was comprised of native-born Protestant Americans, was a group who attacked immigrant religion and culture. This nativist group was particularly troubled by Catholic immigrants and blamed new ethnic groups for being lazy and fomenting crime. This pre-war prejudice led to the newly arriving masses of Irish immigrants to unite behind their ethnicity and their shared diasporic experiences. Throughout the first year of the war, ethnic heritage continued to unite the group due to their service to the Union. Through service in ethnic and non-ethnic regiments, the Irish American press, and the treatment of prominent Irish Catholics by native-born Americans, the Irish became better aware of their shared identities, which in turn made them a more unified group. Although tensions towards the war would only intensify throughout 1862 and 1863, fissures existed before this point, which can be seen among the New York Irish-American community.

The Irish who immigrated to the United States throughout the nineteenth century were not given a warm welcome from native-born Americans. Starting in the 1830s and continuing up to the war itself, wave after wave of immigrants left Europe and immigrated to the United States in search of political freedom and economic opportunity. Most of these immigrants were of Irish, German, and to a lesser extent, Scandinavian descent. The majority landed in the major port cities of the northeast and remained there, however a sizable number traveled to the Midwest and 
either congregated in cities or in small, often ethnically segregated, rural communities. Unlike the previous Irish immigrants that came to the United States before them, this new group of immigrants was largely of the Catholic faith, which challenged the predominantly Protestant population in America. ${ }^{1}$

The sheer number of poor Irish Catholic immigrants caused anxiety and fear among Protestant Americans throughout the early decades of the nineteenth century. Anti-Catholic sentiment was especially strong when large numbers of immigrants settled together and caused native-born Americans to feel as though their Protestant culture and traditions were being threatened. In the 1830s, anti-Catholic sentiment became a fixture in northeastern cities such as New York, Boston, and Philadelphia. ${ }^{2}$ The masses of Irish poor in the cities, as well as the amount of property owned by the Catholic Church, caused native-born Americans to take drastic steps to sway immigration into the United States.

Protestant Americans became increasingly paranoid over the mass of Catholics arriving to the United States throughout the antebellum period. Prominent inventor Samuel F. B. Morse advised his fellow Americans to "Awake! To your posts!" and "Place your guards...[and] shut your gates!"33 He continued to spread fear and warned about the threat of Catholic immigrants. In a series of letters he published, Morse claimed the monarchies of Europe were working with the Catholic Church to subvert the spread of democracy in America by sending Catholic immigrants to the United States. He detested the fact that Irish immigrants did not relinquish the customs and beliefs of their homeland when they came to America by stating, "The Irish naturalized citizens

\footnotetext{
${ }^{1}$ The standard works that examine antebellum immigration and native-born reactions to these groups include Ray Allen Billington, The Protestant Crusade, 1800-1860: A Study of the Origins of American Nativism (New York: Macmillan, 1938); Dale T. Knobel, “America for the Americans.” The Nativist Movement in the United States (New York: Twayne Publishers, 1996); and Tyler Anbinder Nativism and Slavery: The Northern Know Nothings and the Politics of the 1850s (New York: Oxford University Press, 1992).

${ }^{2}$ Anbinder, Nativism and Slavery, 9.

3 Thomas H. O’Connor, The Boston Irish: A Political History (Boston: Back Bay Books, 1995), 43-44.
} 
who should know no other name than Americans, for years have clanned [sic] together as Irish, and every means has been used, and is still used, especially by Catholics, to preserve them distinct from the American family." "Newspapers such as the New York Observer, the Boston Recorder, and the Christian Spectator joined Morse in attacks against "Popery in the United States. $" 5$ These papers, along with radical Protestant ministers such as Reverend Henry Ward Beecher, an abolitionist and brother of Harriet Beecher Stowe, decried what he saw as the immorality of the Catholic Church's teachings and the submissiveness demanded by the Pope of his followers. Like Morse, Beecher worried that Catholicism posed a threat to the democracy of the United States and called for Protestants to rise up against the menaces to the nation. ${ }^{6}$

Anti-Catholic paranoia erupted in 1834, when rumors of torture in a Catholic convent spread throughout the press. Six Months in a Convent, written by Rebecca Reed, was a fabricated story that told of her traumatic experiences and escape from the Ursuline convent in Charleston, Massachusetts, just outside of Boston. Reed's book told of abusive nuns and strange Catholic rituals, which reinforced her Protestant readers' deeply held prejudices against Catholics. ${ }^{7}$ The practices of the convent left the local Protestant population suspicious even before the book's publication, even though some of the city's wealthiest families sent their daughters to be educated there. However, these young women were exposed to very little Catholicism because the Ursuline convent's head Sister adjusted the religious services and classroom teachings to accommodate the large Protestant student body. ${ }^{8}$ This information did not matter to those who read Reed's book, however. Six Months in a Convent quickly became a best-selling novel,

\footnotetext{
${ }^{4}$ Samuel F. B. Morse, Foreign Conspiracy Against the Liberties of the United States (New York: Van Nostrand \& Dwight, 1836), 12, 117 (emphasis in original).

${ }^{5}$ New York Observer, January 23, 1834.

${ }^{6}$ O'Connor, The Boston Irish, 43-44.

${ }^{7}$ Rebecca Reed, Six Months in a Convent: The Narrative of Rebecca Theresa Reed (Boston, MA: Russell, Odiorne $\&$ Metcalf, 1835).

${ }^{8}$ O'Connor, The Boston Irish, 45.
} 
selling over ten thousand copies in its first week of publication. By the end of the first month, two hundred thousand copies had been purchased, reinforcing the fears and prejudice against Catholic immigrants not only in New England but also across the country. ${ }^{9}$

Fear of Catholics turned to violence in August 1834, after rumors spread that nuns kidnapped a woman and forced her to remain within the Ursuline convent against her will. On the night of August 11, a mob stormed and set fire to the convent. The men, along with the fire companies that arrived, watched as the flames engulfed the building. The Ursuline convent eventually burnt to the ground, and while Bostonians denounced the violence, many chose to applaud the motivations of the mob and their attempt to sway Catholic power in America. ${ }^{10}$ In the following years, similar anti-Catholic violence became common in cities like New York and Philadelphia. On May 6, 1844, anti-Catholic riots occurred in the Irish Catholic dominated Kensington district of Philadelphia. Dozens of Catholics lost their homes, two Catholic churches were destroyed, and sixteen Catholics were killed in the fighting. The violence was directed specifically to Irish Catholics, as Protestant rioters passed several German Catholic churches and left them unscathed. ${ }^{11}$

The growing fear of Catholics, coupled with the popular print industry of the early nineteenth century, created a perfect climate for the 1836 publication of Maria Monk's book, Awful Disclosures of the Hotel Dieu Nunnery of Montreal. This book went beyond the claims made by Rebecca Reed and both captivated and horrified Protestant Americans. With its tales of illicit sexual practices that took place in the Catholic convent, it sold more copies in America

\footnotetext{
${ }^{9}$ The estimates of sales are presented by Billington, The Protestant Crusade, 90-109.

${ }^{10}$ O'Connor, The Boston Irish, 45-46.

${ }^{11}$ Dennis Clark, The Irish in Philadelphia: The Generations of Urban Experience (Philadelphia: Temple University Press, 1973; reprint, Philadelphia: Temple University Press, 1984), 21-22.
} 
than any other book until the publication of Uncle Tom's Cabin sixteen years later. ${ }^{12}$ Nunnery stories like these contributed to the mounting current of anti-Catholicism in the first few decades of the nineteenth century. These nativist actions show that even as America extended welcome to immigrant groups, a deep fear was present and grew stronger against ethnic groups who held different beliefs. This ultimately led to ethnic communities like Irish Catholics to unite and look inward behind their religious and cultural heritage, while also adopting elements of American identity. Therefore, the ethnic group continued to push for greater rights for themselves and their families in the United States. ${ }^{13}$

Anti-Catholic nativist fears only escalated during the next few decades due to the Great Irish Potato Famine, which ushered in the largest immigration of Irish Catholics in United States history. Between 1845 and 1855, nearly 1.5 million Irish, mostly belonging to the Catholic faith, left Ireland and came to the United States for asylum. The devastating potato blight meant nearly an entire generation left their Emerald Isle, with only one in three Irish males born around 1831 dying in Ireland of old age. This group of Irish exiles reached the major port cities of the northeast in such dire poverty, with eighty to ninety percent classified as unskilled workers, that very few were able to move west. Ninety percent of the famine exiles were Catholic and as many as one third spoke only Gaelic. ${ }^{14}$ Due to their large numbers and the nativist prejudice they often encountered upon arrival to the United States, Irish immigrants created ethnic communities, which ultimately created more worry and anxiety among native-born Americans.

\footnotetext{
12 Maria Monk, Awful Disclosures of the Hotel Dieu Nunnery (1836, reprint Hamden, CT: Archon Books, 1962).

${ }^{13}$ For an excellent analysis of the rapid expansion and transformation of the print industry in antebellum America, see Paul Erikson, "New Books, New Men: City-Mysteries Fiction, Authorship, and the Literary Market," Early American Studies 1, no. 1 (Spring 2003): 273-312.

${ }^{14}$ Kerby A. Miller, Emigrants and Exiles: Ireland and the Irish Exodus to North America (New York: Oxford University Press, 1985), 291, 296-297.
} 
Although immigrants found refuge all across the United States, the cities of the Northeast became the home of most of Ireland's exiles. New York emerged as the premier port of entry for immigrants from Ireland. With so many of these individuals arriving in dire poverty, few could move elsewhere, which made New York a heavily Irish city. Between 1845 and 1851, New York housed twelve percent of America's Irish population. ${ }^{15}$ By 1860, New York had more than 200,000 Irish-born individuals out of a total population of about $800,000 .{ }^{16}$ Native-born Americans took particular insult when immigrants refused to adopt United States Protestant traditions. The New York Herald angrily reported that the Irish,

have come to us steeped in ignorance and superstition; we have let them have their priests and their churches.... They have so behaved themselves that nearly seventy-five per cent of our criminals and paupers are Irish; that fully seventy-five per cent of the crimes of violence committed among us are the work of Irishmen; that the system of universal suffrage in large cities has fallen into discredit through the incapacity of the Irish for self-government. ${ }^{17}$

As this Catholic foreign-born population grew larger, the anti-immigrant crusade also grew in intensity, size, and political power.

As Americans looked at their cities bulging with poor foreign-born Catholic immigrants, paranoia and fear escalated and eventually developed into political backlash. The pinnacle of American xenophobia came with the rise of the Order of the Star-Spangled Banner, also called the American Party, but most well known as the Know Nothing Party, due to the group's habit of

\footnotetext{
${ }^{15}$ Hasia R. Diner, “'The Most Irish City in the Union:’ The Era of the Great Migration, 1844-1877," in The New York Irish eds. Ronald H. Bayor and Timothy J. Meagher (Baltimore: The Johns Hopkins University Press, 1996): 91.

${ }^{16}$ Ira Rosenwaike, Population History of New York City (Syracuse, NY: Syracuse University Press, 1972), 41.

${ }^{17}$ New York Herald, October 20, 1860. Nativism no doubt influenced these statistics. However, given IrishAmerican poverty, it was true that the ethnic group dominated New York crime statistics and prison populations. In New York in 1850, Irish-born Americans were convicted five times to every native- or German-born American. See Miller, Emigrants and Exiles, 320; Similarly, the Irish accounted for sixty percent of the almshouse population of New York City in the 1850s and more than half of those were arrested for drunkenness. By 1855, the Irishdominated Sixth Ward had the highest death rate in the city. While much of this can be attributed to poverty and not crime, native-born Americans associated the Irish with violence and crime. See Graham Hodges, "Desirable Companions and Lovers:' Irish American and African Americans in the Sixth Ward, 1830-1870," in The New York Irish eds. Ronald H. Bayor and Timothy J. Meagher (Baltimore: The Johns Hopkins University Press, 1996): 114.
} 
denying knowledge of the organizations secret traditions. The group's members comprised of white Protestants who viewed immigrants, particularly Catholics and their beliefs, as threatening to America and its Protestant cultural traditions. ${ }^{18}$ The Know Nothings' popularity grew throughout the mid-nineteenth century, especially as waves of Irish Catholics arrived and clung to their cultural and religious beliefs rather than adopt the Protestant traditions of the United States. The party made great strides in the elections of 1854 and 1855 across parts of the North, with their greatest victories came in Massachusetts, where they took control of the governor's office and both houses of the state legislature. ${ }^{19}$

As slavery became an increasingly divisive topic in American politics throughout the 1850s, the Know Nothings attracted large numbers of Free Soilers and anti-slavery activists who also viewed Irish Catholics as nuisances who supported the pro-slavery movement. Abolitionist William Lloyd Garrison mirrored this view when he stated in the 1840s that, "It is a most deplorable circumstance that, religiously and politically, almost the entire body of the Irishmen in this country are disposed to go with the accursed South for any and every purpose, and to any extent....They are a mighty obstacle, therefore, in the way of the negro emancipation on our soil." ${ }^{20}$ Similarly, a Know Nothing lodge in Massachusetts insisted, "there can be no real hostility to Roman Catholicism which does not embrace slavery, its natural co-worker in opposition to freedom and republican institutions. ${ }^{" 21}$ As these feelings intensified, Irish Catholics became more aware of nativist disapproval of them.

\footnotetext{
${ }^{18}$ As historian Dale Knobel has shown, antebellum Americans linked nativist beliefs with nationalism. See Knobel, America for the Americans, 99-100.

${ }^{19}$ Anbinder, Nativism and Slavery, 91-94.

${ }^{20}$ William Lloyd Garrison, The Letters of William Lloyd Garrison: No Union with the Slaveholders, 1841-1849, vol. 3, ed. Walter McIntosh Merrill (Cambridge, MA: The Belknap Press of Harvard University Press, 1973), 284-285.

${ }^{21}$ Quoted in Anbinder, Nativism and Slavery, 45.
} 
Although the Know Nothings gained a quick following, mismanagement, corruption, and problems surrounding its stance on slavery led to the party's demise. As slavery became a more controversial topic, Northern and Southern members of the party struggled to find common ground. By 1859, the party fell apart and many of the old Know Nothings became Republicans by 1860 . Although this new party never officially adopted an anti-immigrant stance, its members' nativist predilections remained. ${ }^{22}$ While Irish Americans had good reason to mistrust both major parties in the United States, most chose to use their newly acquired voting rights and side with the Democratic Party. The Irish overwhelmingly sided with the Democratic Party because they felt it provided the greatest chance to support their ethnic interests. As historian William Burton has argued, "Germans and other groups of the foreign born participated in both major parties" but "for Irish-Americans this involved an often decisive voice in Democratic party affairs." 23

Even though the Irish in America overwhelmingly sided with the Democrats, the abolitionist cause had many similarities to the ethnic group's struggle with English rule at home. Irish nationalist and leading figure in the Irish Repeal Movement, Daniel O'Connell, found support from American abolitionist William Lloyd Garrison, when he demanded home rule in Ireland. ${ }^{24}$ O'Connell's attempts and eventual success in securing religious freedom in Ireland made him a leading advocate for the emancipation of enslaved people in the United States.

\footnotetext{
${ }^{22}$ Anbinder, Nativism and Slavery, 246

${ }^{23}$ William L. Burton, Melting Pot Soldiers: The Union's Ethnic Regiments (New York: Fordham University Press, 1998), 29.

${ }^{24}$ Irish opposition emerged throughout the nineteenth century due to the Act of Union of 1800, which merged the two separate Kingdoms of Ireland and Great Britain into one. In the 1830s and 1840s, attempts were made by the Irish under the leadership of Daniel O'Connell and his Repeal Association to repeal the Act of Union and restore Ireland as a separate kingdom. See W. Caleb McDaniel, The Problem of Democracy in the Age of Slavery: Garrisonian Abolitionists and Transatlantic Reform (Baton Rouge: Louisiana State University Press, 2013); Cian T. McMahon, The Global Dimensions of Irish Identity: Race, Nation, and the Popular Press, 1840-1880 (Chapel Hill: The University of North Carolina Press, 2015); and Angela F. Murphy, American Slavery, Irish Freedom: Abolition, Immigrant Citizenship, and the Transatlantic Movement for Irish Repeal (Baton Rouge: Louisiana State University Press, 2010).
} 
O'Connell called for Irish Americans to "treat the colored people as your equals, as brethren. By all your memories of Ireland, continue to love liberty—hate slavery—CLING BY THE ABOLITIONISTS - and in America you will do honor to the name of Ireland."25

Garrison and other abolitionists hoped Irish Americans would support the antislavery messages of their fellow Irishman Daniel O'Connell, however this was not the case. Archbishop John Hughes, who was a central figure for the New York Irish, and for Irish Catholics across America, thought O'Connell's speech was fabricated. Hughes proclaimed, "I am not a friend to slavery, but I am still less friendly to any attempt of foreign origin to abolish it.” He argued, that it is the duty of every naturalized Irishman to resist and repudiate the address with indignation.... And if it be proved an attempt has been made by this address, or any other address, to single them [naturalized Irish] out on any question appertaining to the foreign or domestic policy of the United States, in any other capacity than that of the whole population, then it will be their duty to their country and their conscience, to rebuke such an attempt to come from what foreign source it may, in the most decided manner and language that common courtesy will permit. ${ }^{26}$

Irish American animosity to African Americans was something former slave and abolitionist Frederick Douglass pointed to as well. At the American and Foreign Anti-Slavery Society anniversary meeting held in New York in 1853, he stated that "the Irish, who, at home, readily sympathize with the oppressed everywhere, are instantly taught when they step upon our soil to hate and despise the Negro.... The cruel lie is told them, that we deprive them of labor and receive the money which would otherwise make its way into their pockets." ${ }^{27}$

Although Ireland's struggles resembled those of African Americans in the United States, Irish Americans still had reason to support the Democratic Party rather than the newly created

\footnotetext{
${ }^{25}$ Daniel O'Connell, Daniel O'Connell Upon American Slavery: With Other Irish Testimonies (New York: Published by the American Anti-Slavery Society, 1860), 40 (emphasis in original).

${ }^{26}$ Liberator, March 25, 1842.

${ }^{27}$ Frederick Douglass, Life and Times of Frederick Douglass, ed. Henry Louis Gates Jr. (New York: Pathway Press, Inc., 1941), 330.
} 
Republican Party. Their Catholic faith played a critical role on how Irish Americans viewed issues of the time. Catholics believed that because civil power came from God, one had to obey the laws of a nation unless they specifically contradicted the laws of God. This meant that while some saw slavery as immoral, the laws supporting it had to be obeyed. However, this was not how native-born Americans saw the large Irish voting bloc. A New York newspaper used similar rhetoric as Samuel F. B. Morse when it wrote, "Under its present rule of spiritual teaching we can regard the Catholic Church in no other light than as a political institution, whose purpose is to strengthen the chains of slavery, and build up a corrupt political dynasty pledged to its perpetuation in a free country." ${ }^{28}$ Irish Americans felt as though they were under attack from Republicans even as they made great strides to participate in American democracy. The New York Irish American wrote in response to repeated attacks by the Republican newspaper, the New York Tribune. The Irish newspaper wrote, "Let any one point out where the Irish adopted citizens of this Republic have failed in the allegiance they swore to the Constitution, or made that allegiance subordinate to any interest, social or personal, and we will acknowledge the justice of the charge. ${ }^{29}$ A later article from the same paper simply described Republicans as "niggerloving" and "Celt-hating." 30

For the Irish in America, support for the Republican Party meant that they would have to embrace the very group that supported the emancipation of the slave while ignoring the suffering masses of Irish immigrants in the North. In so doing, the Irish American ethnic communities created a strong voting bloc in the antebellum period. The decision of Irish Americans to overwhelmingly support the Democratic Party also demonstrates the way the ethnic group

\footnotetext{
${ }^{28}$ Quoted in the Irish American, November 24, 1855; See Robert Francis Hueston, The Catholic Press and Nativism, 1840-1860 (New York: Arno Press, 1976) for an excellent look at Nativist attacks towards America's antebellum Catholic population.

${ }^{29}$ Irish American, August 14, 1858.

${ }^{30}$ Irish American, October 22, 1859.
} 
diverged from many of their family and friends in the Emerald Isle. It also shows the ways the ethnic group used their newly acquired voting rights, which was distinctly American in identity, to enact change for themselves and their communities. Through these efforts, they demonstrated the importance American identity played in their lives in the United States, which was something that separated themselves from the Irish who remained in Ireland.

Catholic Irish Americans used their growing political influence and the Catholic Church to challenge some of the Protestant traditions in the United States. Much of this change was achieved through the direction and power of the Archbishop of New York, John Hughes. Archbishop Hughes worked diligently to unite the Catholics of America together. ${ }^{31}$ Through his followers' devotion and increasing numbers, the Archbishop formed a powerful force that improved the Catholic Church and the lives of his followers in the United States. One of the biggest ways Hughes and other Catholic leaders challenged Protestant America was by demanding an end to Bible readings in the public school system. This was not because Catholics disagreed with Bible readings but rather that the public schools read from the Protestant King James Bible. In New York, Pennsylvania, Maryland, and Ohio, Catholics lobbied state legislatures to provide public funds for the teaching of Catholic doctrines in public schools. ${ }^{32}$ Although it is important to understand how much their ethnicity played in this effort, it is also important to acknowledge how crucial their identity as Americans was to implement these changes. Without their newfound power within Americans democracy, their challenges against Protestantism would not have been possible.

\footnotetext{
${ }^{31}$ The best works on Archbishop John Hughes include John Loughery, Dagger John: Archbishop John Hughes and the Making of Irish America (Ithaca, NY: Cornell University Press, 2018); Charles R. Morris, American Catholic: The Saints and Sinners Who Built America's Most Powerful Church (New York: Vintage Books, 1997); and Richard Shaw, Dagger John: The Unquiet Life and Times of Archbishop John Hughes of New York (New York: Paulist Press, 1977)

${ }^{32}$ William B. Kurtz, Excommunicated from the Union: How the Civil War Created a Separate Catholic America (New York: Fordham University Press, 2016), 136-138.
} 
Irish American's socioeconomic proximity to free or enslaved African Americans also contributed to the ethnic group's hatred towards the Republican Party of the United States. The Irish, more than any other immigrant group in mid-nineteenth-century America, arrived as unskilled laborers. Upon arrival to New York, most of the famine-Irish were too poor to move beyond the city, and Irish Catholics routinely found the lowest paying jobs. Historians have estimated that in 1850s Boston, twenty-two percent of German-born immigrants compared to six percent of Irish-born immigrants found non-manual jobs. Similarly, fifty-seven percent of Germans worked as skilled laborers in the United States, while only twenty-three percent of Irish immigrants could say the same. In fact, Boston's free black population was more economically and socially secure than the Irish population at this time. This was not unique to Boston either, with Germans being twice as likely to do non-manual labor than the Irish in New York City in the mid 1850s as well. ${ }^{33}$

While Irish men often struggled to find steady work in the United States, Irish women came to dominate the service industry by the middle of the nineteenth century. Even in the North, most white Americans considered domestic service belittling and, if possible, refused to take positions commonly held by African Americans. ${ }^{34}$ "Domestic service in the United States is considered as degrading by all [Americans] untainted by the curse of African descent" wrote one contemporary source. ${ }^{35}$ Unlike native-born white women, newly immigrated Irish women did not have this luxury, and many found themselves working as domestic house servants. By 1855 , nearly three quarters of New York's domestic servants were Irish and this trend continued on

\footnotetext{
${ }^{33}$ David R. Roediger, The Wages of Whiteness: Race and the Making of the American Working Class (London: Verso, 2007), 145.

${ }^{34}$ See Faye E. Dudden, Serving Women: Household Service in Nineteenth Century America (Middletown, CT: Wesleyan University Press, 1983).

${ }^{35}$ Thomas Hamilton, Men and Manners in America (Philadelphia, PA: Carey, Lea \& Blanchard, 1833), 63.
} 
throughout the antebellum period and beyond. ${ }^{36}$ Other Irish-American women who could not find jobs as domestic servants or laborers in factories or mills often took to the streets. In $1850 \mathrm{~s}$ New York City, Irish women made up a large part of the city's prostitutes. ${ }^{37}$ For these reasons, Irish laborers were frequently referred to as "white slaves" and "white niggers," due to their similar socioeconomic status to African Americans.

Irish-American men often looked to the military as a plausible way to improve their lives in the United States, however large numbers of immigrants in U.S. service caused fear and anxiety as well. Service in the military offered a steady income for immigrants, which included room and board. It also allowed poor, unskilled immigrant laborers to escape the oppressive tenement buildings and squalor of the cities. For these reasons, the American military had a growing ethnic representation beginning in the early nineteenth century. Due to nativist fears, this led military officials to restrict foreign enlistment. However, recruitment numbers in the eastern cities began to seriously decline. By the late 1840s, restrictions on immigrant enlistments were removed with the exception that all recruits must have a "competent knowledge of the English language." 38 These changes, along with the permanence of military service proved attractive to immigrants. In the first two years of the 1850 s, foreigners comprised the majority of the United States Army. Out of the approximately 5,000 enlistments during these two years less than 1,500 were native-born, while over 3,500 were European immigrants and of these, 2,113 came from Ireland. ${ }^{39}$

\footnotetext{
${ }^{36}$ Robert Ernst, Immigrant Life in New York City, 1825-1863 (New York: King's Crown Press, 1949), 219.

${ }^{37}$ Christine Stansell, City of Women: Sex and Class in New York, 1789-1860 (New York: Knopf, 1986), 178.

${ }^{38}$ M. H. MacNamara, The Irish Ninth in Bivouac \& Battle, or Virginia and Maryland Campaigns (Boston: Lee and Shepherd, 1867), 5-17.

${ }^{39}$ Richard H. Coolidge, Statistical Report on the Sickness and Mortality in the Army of the United States, Compiled from the Records of the Surgeon General's Office, Embracing a Period of Sixteen Years, from January 1839 to January 1855 (Washington, D.C.: A.O.P. Nicholson, 1856), 627.
} 
Irish immigrants who found their way into the ranks of the United States Army often faced nativist prejudice. Much of this nativism stemmed from Irish Catholic soldiers' unfamiliarity or unwillingness to adopt American customs and traditions, specifically the Protestant faith. Anti-Catholicism in the military became more recognizable throughout the 1840s as tensions between the United States and Catholic Mexico increased. Editors of Protestant papers throughout the Mexican American War reported on priests urging their followers to refrain from joining the war, of chaplains aggressively converting American Protestants, and of Irish-American deserters. Even as some Irish Catholics gained recognition for their service, Irish Americans were constantly confronted with news of United States soldiers pillaging Catholic churches in Mexico and continued religious discrimination among the ranks. ${ }^{40}$

The divisions between New York's Irish and the native-born population continued throughout the antebellum period and reached a climax in the months preceding the 1860 presidential election. Native-born Americans anxiously anticipated the October visit of the Prince of Wales, son of Queen Victoria, and future ruler of Great Britain. Famed New York City diarist George Templeton Strong recalled that the Prince of Wales's visit "has occasioned a week of excitement beyond that of any event in my time..." ${ }^{41}$ Irish Americans felt differently however. Members of the 69th New York State Militia, which was made up almost entirely of Irish immigrants and was led by Irish exile Michael Corcoran, planned to excuse themselves from the parade. ${ }^{42}$ Strong noted Irish discontent towards the prince's visit when he wrote, "the protest of

\footnotetext{
${ }^{40}$ Kurtz, Excommunicated from the Union, 18-20; The actions of the San Patricio Battalion negatively affected the way Irish Catholic service in the Mexican-American was remembered. Irish-born and Catholic deserter John Riley led the San Patricios. The battalion composed largely of American deserters of foreign birth but also included native-born Americans and Mexican citizens.

${ }^{41}$ George Templeton Strong, Diary of the Civil War, 1860-1865, ed. Allan Nevins (New York: The Macmillan Company, 1962), 51.

${ }^{42}$ Corcoran was also a high-ranking member of the Irish Republican Brotherhood in America. This was an Irish nationalist organization better known as the Fenians. The Fenians chose their name as a reference to the Fene or Fianna, who were great warriors and defenders of ancient Ireland.
} 
certain militia companies of Irishmen against the parading to do honor to a Saxon and an

oppressor of Ireland is the single exception." ${ }^{43}$ Corcoran and other Irishmen in the 69th New

York State Militia saw the Prince of Wales as an oppressor of Ireland because England insisted it

had the right to rule the Emerald Isle. ${ }^{44}$ Even though the 69 th was one of the units ordered to

parade for the prince, the Irishmen voted to excuse themselves from the festivities. On the day of

the parade, the 69th did not appear, which left Corcoran to explain the actions of his unit.

Corcoran argued, "that in the Prince of Wales I recognized the representative of my country's

[Ireland] oppressors, that in my opinion no change of circumstance should efface the memory of

the multiplied wrongs of fatherland, and, that in honoring that personage, I should be

dishonoring the memories, and renouncing the principles, of that land of patriots." 45

While Irish Americans understood and applauded Corcoran's decision, native-born

Americans did not agree. Military authorities arrested Corcoran on charges of disobedience and ordered him to face a court-martial trial. Even though large numbers of Irishmen showed their support for the United States by serving in American militias, Anglo Americans saw this as yet another example of Irish immigrants refusing to adopt American customs and exploded in anger. Harper's Weekly explained that the Irish, "as militiamen and soldiers...have not unfrequently

\footnotetext{
${ }^{43}$ Strong, Diary of the Civil War, 51.

${ }^{44}$ In 1845, one of the worst famines hit Ireland and the small island turned to the British for support. The British had the power to mediate the suffering, yet chose to hold back. Despite initial aid put in place by Sir Robert Peel, which lessened the impact of the blight on the agrarian society, there was little hope in store for Ireland. In the years that followed, the matter only intensified due to the administration of Lord John Russell. With the slow termination of support, the Irish were left to their own means of survival. Due to the influence of laissez-faire economics in congruence with Britain's ethnic and religious preconceptions, the famine in Ireland escalated to astronomical proportions. Whether it be economic excuses or religious and ethnic justifications, the lives of millions of Irish were struck by devastating poverty and eventual death. For information on the Irish Potato Famine and Britain's role in the matter, see Kevin Kenny, Ireland and the British Empire (New York: Oxford University Press, 2004); Richard N. Lebow, White Britain and Black Ireland: The Influence of Stereotypes on Colonial Policy (Philadelphia: Institute for the Study of Human Issues, 1976); and Edward G. Lengel, Irish through British Eyes: Perceptions of Ireland in the Famine Era (Westport, CT: Praeger, 2002).

${ }^{45}$ Irish American, March 23, 1861.
} 
been an absolute nuisance." If this was not enough, the paper continued its argument when it stated:

It is not worth while to repeat the story of the two Irish regiments which served under General Van Rensselaer, in the war of 1812, or of the Irishmen who deserted from our army and constituted the battalion of San Patricio, in the Mexican war.... [and] the spectacle of the ignominious surrender of the Irishmen in Lamoricière's army, who had volunteered to assist the Pope in keeping down his Italian subjects, has not yet been forgotten. Before our Irishmen thrust themselves anew under the public nostril they should allow the effluvia of this transaction to pass away. ${ }^{46}$

As Irish Americans united behind their ethnic heritage, native-born Americans saw this as proof that the ethnic group purposely disrespected the United States and its guest.

Irish Americans viewed Corcoran's decision differently however, and saw his action as a necessary stance against an oppressor of their homeland. The Irish American saw the courtmartial against Corcoran as nativist prejudice from the Republican Party when it argued, "Is it possible that Americans generally do not respect both officers and regiment much more for their spirited refusal?" The paper continued, saying, "I find it very difficult to conceive that Col. Corcoran is actually to be tried by a Court Martial for this military offence: but, perhaps, it means only that the predominant Black Republican party of New York designs to use the first pretext for disbanding and getting rid of the Irish Militia companies, as has been done long since in Massachusetts and other States. ${ }^{47}$ Irish American John Mitchel reflected the opinions of many others in the ethnic group when he stated that "arresting Col. Corcoran and threatening him with a Court Martial, must be regarded as in themselves highly offensive and insulting to every naturalized Irishman, and must certainly so be felt. It was intended to demonstrate ostentatiously in how very small account Americans hold the feelings, the wrongs and the memories of their

${ }^{46}$ Harper's Weekly, October 20, 1860.

${ }^{47}$ Irish American, January 5, 1861. 
Irish fellow-citizens. ${ }^{48}$ This event proved to Irish Americans in New York and elsewhere that they were not welcome in the United States and proved how important uniting behind their ethnic identity was when defending their Irishness. It also demonstrates the different ways Irish Americans and native-born Americans understood what it meant to be American.

Anger over Corcoran's court martial, along with nativist prejudice throughout the early nineteenth century, left Irish Americans overwhelmingly in support of the Democratic Party in the 1860 election. Republican candidate Abraham Lincoln came from a party that contained abolitionists, which led the ethnic group to praise the Democratic candidate Stephen Douglas. Irish support for Douglas and the Democrats was also tied to the economic impact that Lincoln's victory and emancipation might bring. The New York Herald warned Americans that "if Lincoln is elected you will have to compete with the labor of four million emancipated Negroes." ${ }^{49}$ Irish, as well as many native-born Americans, worried that the abolition of slavery would cause an exodus of African Americans to the North and cause havoc to the already uncertain and difficult labor market. This left many to place their identity as Democrats above their ethnic identity during the 1860 election.

As Corcoran remained in prison awaiting trial, New Yorkers became more preoccupied with the presidential election and the growing tension within the nation. Abraham Lincoln's victory in November 1860 brought the divisions in the United States to a breaking point, with radical South Carolina voting to secede from the Union that December. As leaders in the IrishAmerican community urged their followers to accept the election results, they also voiced sympathy to the South. The editors of the Irish American voiced their disagreement with the actions of South Carolina when it stated, "The 'madness of the hour' has reached its height in

\footnotetext{
${ }^{48}$ Irish American, January 19, 1861.
}

${ }^{49}$ New York Herald, November 6, 1860. 
South Carolina. At this moment the Secession party in that State are engaged in open rebellion against the authority of the United States, have levied war against the Republic, and seized its property quite as illegally as did John Brown when he surprised and captured the armory at Harper's Ferry." However, the paper similarly discredited Lincoln's actions when it argued, "No sane individual supposes that, had the President done his duty, as he was sworn to do it, and places the forts in Charleston harbor in an efficient state of defence, the Secessionists would have dared to attack them, or that the disgrace would have befallen us of seeing the property of the Republic abandoned and destroyed in one of its principal seaports." $" 50$

Along with nativist sentiment, Anglo Americans had reason to doubt Irish-American support for the North. Likewise, many of the Irish community's chief spokesmen expressed prosouthern opinions during the antebellum period. Radical Irish nationalist John Mitchel provides the best example of this. Mitchel, who relocated to the South and became an ardent supporter of the Confederacy during the Civil War, viewed the South and Ireland similarly. ${ }^{51}$ In the spring of 1859, Mitchel claimed that "the North, being a trading, manufacturing, ship-owning, and speculative community, has long labored to obtain control of the South and the use and profit of her agricultural industry; just as England has obtained control over Ireland." 52 While Irish Americans supported the Union throughout the Civil War, many remained sympathetic towards Mitchel due to the Irish heritage they shared. Even Thomas Francis Meagher, the future leader of the Irish Brigade, voiced sympathies for the South when he stated, "You cannot call eight millions of white freemen 'rebels,"” and felt "revolutionists" was a more fitting term.

\footnotetext{
${ }^{50}$ Irish American, January 5, 1861.

${ }^{51}$ For the best look on Irishman John Mitchel, see Bryan P. McGovern, John Mitchel: Irish Nationalist, Southern Secessionist (Knoxville: The University of Tennessee Press, 2009); To understand how Mitchel's movement fit into an early era of nationalism, see Andre Fleche, The Revolutions of 1861: The American Civil War in the Age of Nationalist Conflict (Chapel Hill: University of North Carolina Press, 2012).

52 Southern Citizen, n.d.; reprinted in the Irish American, May 14, 1859.
} 
Supportive opinions from Irish Americans towards the South quickly swung behind the Union after Confederate forces fired on the Federal arsenal at Fort Sumter, South Carolina. Irish Americans volunteered for the Union in astonishing numbers. While many served in non-ethnic regiments, thousands chose to draw attention to their ethnic background by fighting in solely Irish units. The most famous of these units was the Irish Brigade, led by Thomas Francis Meagher. Meagher explained his decision to fight and support the Union in the midst of Republican and abolitionist ideals by stating:

Duty and patriotism alike prompt me to [join the Union]. The Republic, that gave us an asylum and an honorable career, - that is the mainstay of human freedom, the world over-is threatened with disruption. It is the duty of every libertyloving citizen to prevent such a calamity at all hazards. Above all is it the duty of us Irish citizens, who aspire to establish a similar form of government in our native land. It is not our duty to America, but also to Ireland. We could not hope to succeed in our effort to make Ireland a Republic without the moral and material aid of the liberty-loving citizens of these United States. ${ }^{53}$

Other Irishmen who served under Meagher held similar beliefs. William McCarter, an Irishman in the 116th Pennsylvania believed that he owed his life to his adopted country. McCarter explained, "not the North nor the South, nor the East nor the West, but the Union, one and inseparable." The Irishman used rhetoric similar to Meagher when he stated, "its form of government, its institutions, its Stars and Stripes, its noble, generous, intelligent and brave people, ever ready to welcome and to extend the hand of friendship to the...oppressed of every clime and people. My full determination was to assist in any way that I could to prevent the Union's dissolution by the traitors of the North, as well as those of the South. ${ }^{, 54}$ While these

\footnotetext{
${ }^{53}$ Michael Cavanagh, Memoirs of General Thomas Francis Meagher, Comprising the Leading Events of His Career Chronologically Arranged, with Selections from his Speeches, Lectures, and Miscellaneous Writings, Including Personal Reminiscences (Worcester, MA: The Messenger Press, 1892), 369.

${ }^{54}$ William McCarter, My Life in the Irish Brigade: The Civil War Memoirs of Private William McCarter, 116th Pennsylvania Infantry, ed. Kevin O’Brien (Cambridge, MA: De Capo Press, 1996), 221.
} 
men placed importance on their ethnicity, their identity as Americans weighed heavily when they chose to fight for the Union and all that it stood for.

Irish American and Catholic newspapers of New York also encouraged ethnic service to the Union. New York's Catholic paper, the Metropolitan Record, captured the feeling of most Irish Americans when it wrote:

Our loyalty, our fealty, our allegiance is due to the Government of the United States, and in this country we recognize none other. The Constitution under which the nation has marched in a most unexampled career of prosperity is good enough for us, and will remain so until in accordance with its own provisions, such changes may be effected in it as the required majority of the people may deem necessary. We have always loved the flag of the Union, we have seen it wave over stormy and tranquil seas; it has ever been to us the emblem of popular freedom and self-government; we have glorified in its triumphs, and we trust in God that despite the terrific convulsion through which the country is now passing that it will once more be the flag of a united and prosperous people. ${ }^{55}$

The New York Irish American also stressed the support its immigrant readers provided to the United States against the newly formed Confederacy when it wrote that the Union flag "shall never be trailed in the dust if Irish-American hearts and heads can keep it gloriously aloft." ${ }^{56}$ Irishmen who enlisted into Union service and their loved ones reading the papers at home, were just as enthralled with the outbreak of war as native-born Americans.

Some Irish Americans, such as Irish nationalists like the Fenians, were quick to serve and fight for the Union during the Civil War because it provided training opportunity that the men could use in a later war against England. Thomas Francis Meagher understood that even if Irish blood were lost in the Civil War, it would benefit the fight for Irish nationalism later on. He explained that, "if only one in ten of us [Irishmen] come back when this war is over, the military experience gained by that one will be of more service in the fight for Ireland's freedom than

${ }_{55}^{5}$ Metropolitan Record, April 27, 1861.

${ }^{56}$ Irish American, June 15, 1861. 
would that of the entire ten as they are now." ${ }^{, 57}$ Peter Welsh, who was not a Feninan, thought of the Civil War similarly, describing it as "a school of instruction for Irishmen and if the day should arive [sic] within ten years after this war is ended an army can be raised in this country that will strike terror to the Saxons heart." ${ }^{, 58}$ For these men, Irish ethnic identity was exceedingly important when understanding their service to the Union. American service was something to be used to strengthen and enhance their ethnicity by gaining Irish independence later.

The 69th New York State Militia, which became one of the most famous Irish regiments in the American Civil War, voted almost unanimously to offer their service to the Union once President Lincoln called for 75,000 volunteers to suppress the rebellion. The 69 th presented themselves to New York's Governor Edwin Morgan, as one of the states only regiments with training and discipline, and pushed for the release of their commander, Michael Corcoran. Prominent New Yorkers like businessman James Bowen concurred and argued that the governor should "squash at once the court martial on Col. Corcoran." 59 Governor Morgan eventually agreed and ordered Major General Charles W. Sandford, commander of the First Division N.Y.S.M., to dismiss all charges and order Corcoran and his regiment to prepare to embark for Washington within three days.

Thousands of Irish and native-born Americans flocked to send the 69th New York State Militia off in good spirits as they departed from New York City. Before they departed, Maria Lydig Daly, wife of Irish American Judge Charles Patrick Daly, presented the regiment with a silk American flag. Corcoran declared that the flag would "never suffer a stain of dishonour

\footnotetext{
${ }^{57}$ Cavanagh, Memoirs of General Thomas Francis Meagher, 369.

${ }^{58}$ Peter Welsh, Irish Green and Union Blue: The Civil War Letters of Peter Welsh, Color Sergeant, 28th Regiment, Massachusetts Volunteers, eds. Lawrence Frederick Kohl and Margaret Cossé Richard (New York: Fordham University Press, 1986), 103.

${ }^{59}$ David Power Conyngham, The Irish Brigade and its Campaigns (Glasgow: R \& T Washbourne, 1866), 20.
} 
while a man of the Sixty-ninth remained alive to defend it." ${ }^{\prime 60}$ Along with their new American flag, the 69th carried a green Irish flag, which was a gift from Irish Americans in San Francisco to the regiment for their snub on the Prince of Wales (Figure 1). ${ }^{61}$ As the Irishmen carried the flag of their homeland and their adopted country, they passed old St. Patrick's Cathedral and Hibernian Hall, all the while getting cheered by Irish-American spectators. "Flags and banners streamed from the windows and the house-tops" while "ladies waved their handkerchiefs from the balconies, and fling bouquets on the marching column." Irish Americans cheered their countrymen with a sign nearby that read, "Sixty-ninth, remember Fontenoy" and "No North, no South, no East, no West, but the whole Union." ${ }^{62}$ While service to the Union was important, the New York Irish made sure their ethnic identity would never be forgotten. ${ }^{63}$

Although only in command of the 69th New York, Colonel Corcoran envisioned a larger unit meant for only Irish-American recruits. While his men encamped at Georgetown College, Corcoran received orders from the War Department to increase his force by three hundred men. Included in these numbers were the newly formed Irish Zouaves, commanded by fellow Irish nationalist, Captain Thomas Francis Meagher. While the 69th left for Washington, Meagher began recruitment and called for only Irish volunteers. Like Corcoran, Meagher hoped to build a unit made up solely of Irishmen, so the ethnic group's sacrifice and valor for the Union was recognized. Meagher called "Young Irishmen to Arms! To Arms Young Irishmen!" and within a week, he received 100 recruits. These Irishmen became Company K of the 69th New York State

\footnotetext{
${ }^{60}$ Conyngham, The Irish Brigade and its Campaigns, 12.

${ }^{61}$ Irish American, March 16, 1861.

${ }^{62}$ Conyngham, The Irish Brigade and its Campaigns, 12.

${ }^{63}$ In 1619 the British allowed eleven thousand defeated Irish Catholic soldiers to go to France and serve King James II, who was living in exile there. Many of these soldiers, who became known as the Wild Geese, formed the Irish Brigade that served the French Army. See Miller, Emigrants and Exiles.
} 
Militia. By May 22, the Irish Zouaves had an additional 200 Irish Americans ready to depart for Washington and join the ranks of the 69 th. ${ }^{64}$

Irish Americans throughout the North were eager to fight for the Union, and many looked to serve with other Irishmen in ethnic regiments. Out of the 507 men of the 69th New York Infantry that specified their place of birth, 463 were born in Ireland ${ }^{65}$ For these men, service in an ethnic regiment allowed them to keep a close knit and familiar community within the army. Similarly, the 37th New York Infantry, also known as the "Irish Rifles," filled the ranks in a single week. Irishmen in the 75th New York State Militia made up the core of the new regiment and originally entered military service to prepare for a future battle to free Ireland. ${ }^{66}$ In Illinois, Irish American James A. Mulligan began organizing an Irish unit in April 1861. Within a week, its ranks swelled to over 1000 men and became the 23rd Illinois Infantry, also known as the "Irish Brigade of the West." They too rallied behind their ethnicity and carried a green flag into battle. ${ }^{67}$ Like Corcoran and Meagher, Mulligan dreamed of uniting all the Irish of the Northwest into a single Irish Brigade when he said, "I think, there is an opening for a splendid march for the western Irishman. I'd like to make it at the head of a true Irish Brigade." ${ }^{98}$ Other regiments like the 9th Connecticut Infantry and the 17th Wisconsin Infantry emerged throughout the first year of the war and openly identified themselves as ethnically Irish units. The organizers of these units openly acknowledged their Irish ethnicity and the volunteers who joined the unit did so in part because of this shared identity. The men marched into battle proudly displaying their

\footnotetext{
${ }^{64}$ Cavanagh, Memoirs of General Thomas Francis Meagher, 378-380.

${ }^{65} 69$ th New York Infantry Regimental Descriptive, Letter, Order, and Miscellaneous Book, Records of the Adjutant General's Office, Book Records of Volunteer Union Organizations, Record Group 94, National Archives and Records Administration, Washington, D.C.

${ }^{66}$ Burton, Melting Pot Soldiers, 127.

${ }^{67}$ Ryan W. Keating, Shades of Green: Irish Regiments, American Soldiers, and Local Communities in the Civil War Era (New York: Fordham University Press, 2017), 36.

${ }^{68}$ Quoted in Burton, Melting Pot Soldiers, 138.
} 
ethnicity through their regimental flags and were constantly reminded of their ethnic heritage through reports of their sacrifice and honor in the Irish-American press.

The fact solely ethnic regiments were accepted into Union service was remarkable, considering that many ethnically filled militia units were dissolved in the antebellum period due to nativist hostilities. In Boston, Irish-born Thomas Cass received permission from the governor to organize a regiment of Irishmen to answer Lincoln's call to arms. The ranks of the 13th Massachusetts Volunteer Militia filled quickly, with many of the men having served together in the Columbian Artillery previously. The Columbian Artillery was an Irish militia unit that was dissolved before the war due to ethnic prejudice. Some remained displeased at the fact that Cass was able to recruit the Columbian Artillery, referring to his new regiment as a "load of Irish rubbish." Yet for many, the common struggle against the Confederacy caused most Bostonians to forget such animosity and allow for an Irish regiment to be raised. ${ }^{69}$

Irish-American communities throughout the North showed the importance of ethnicity through Irish enlistment into ethnic regiments and the support they garnered. Ethnic regiments appealed to many Irish immigrants, particularly ones living in the North's major cities. Most Irish Americans in urban areas clustered together in ethnically distinct communities when they arrived in America. For these individuals, contact with native-born Americans was limited, so enlisting in ethnically Irish regiments made sense. Not only would they serve with friends, neighbors, and relatives, but they also continued to be surrounded by people who shared a similar cultural background. Serving in ethnic regiments also allowed these men to somewhat insulate themselves from nativist prejudice in the army. By enlisting in ethnic regiments, Irish

\footnotetext{
${ }^{69}$ Susannah Ural Bruce, The Harp and the Eagle: Irish-American Volunteers and the Union Army, 1861-1865 (New York: New York University Press, 2006), 69.
} 
soldiers became more aware of their shared diasporic identity and allowed them to remain in distinct and separate small communities while in service to the Union.

Even Irishmen who joined non-ethnic regiments tended to gravitate towards one another through their shared identity. In some cases, these men knew each other prior to service, but others developed a bond with those who shared Irish heritage. This was not a response to nativist prejudice within the army for the most part, but rather it was caused by the men who were drawn together by a shared cultural heritage that was reflected in their prewar Irish-American communities throughout the North. Historian Reid Mitchell argued that for many Civil War soldiers, their regimental company "functioned as an extension of the soldier's home community. ${ }^{, 70}$ But for Irish Americans in both ethnic and non-ethnic regiments, this community was strengthened by a shared cultural identity to their Irish ethnicity.

Some Irishmen became better connected to their Irish ethnic identity even through their service in non-ethnic regiments. One regimental company where this seems to have occurred was Company $\mathrm{G}$ of the 26th New York Infantry, also known as the Second Oneida Regiment. ${ }^{71}$ One of the men who enlisted in Company G was eighteen-year-old John Gannon, a native of County Tipperary, Ireland. By 1852, his family had immigrated to the United States, and by May 1861, Gannon was in Rochester, New York, where he enlisted into Union service. ${ }^{72}$ Irishman John Meehan also enlisted in the predominately native-born regiment, which led he and Gannon to become fast friends. During the confusion and chaos of the Second Battle of Manassas in August 1862, John Meehan fell into Rebel hands while his comrade John Gannon went missing. As

\footnotetext{
${ }^{70}$ Reid Mitchell, The Vacant Chair: The Northern Soldier Leaves Home (New York: Oxford University Press, 1995), 21.

${ }^{71}$ Companies $\mathrm{G}$ and $\mathrm{H}$ were originally intended to be part of the 13th New York Infantry and were recruited in Rochester, New York, which was home to a sizeable Irish population.

721860 United States Federal Census, accessed at ancestry.com, November 23, 2019; New York Muster Roll Abstracts of John Gannon, accessed at ancestry.com, November 23, 2019.
} 
Gannon's family wondered his fate, Meehan was taken prisoner before he was paroled that September. ${ }^{73}$ After returning to the regiment, Meehan wrote a letter to John Gannon's mother. Meehan expressed his emotions when he wrote, "it is a painefull peice of information for you to receive and allso for me to have to pen on this as I was to him like a brother and him to me...[as] we both sleept and eate together since we first enlisted in the city of Rochester..." ${ }^{" 74}$ The relationship between these two Irishmen was created through their service to the Union. Although they served in a non-ethnic regiment and reference to their Irishness was not present in the surviving letters, it is clear that it was their shared cultural identity that helped draw them together.

Even as ethnic connections were made in non-Irish regiments, recruiters in the early years of the war made specific attempts to appeal to Irish ethnic pride. Early recruitment posters provide a great example of this, with many linking Irish and American nationalism together through service to the Union. In Boston, Irishmen were presented with posters that called for “The Glorious 9th! Irishmen to the Rescue!" The poster reminded volunteers of the "indomitable valor and bravery which distinguished your ancestors on many a bloody battle-field in past ages" and linked this service to more recent Irishmen who's "bravery and valor, have, to a great extent, thus far, impeded the march of the [Southern] vandals...” The poster appealed to Irish nationalism and Catholic pride when it noted that the green Irish flag went hand-in-hand into battle with the Stars and Stripes and promised that the regiment would have "a chaplain of the old faith"75 (Figure 2). Other Irish regiments made similar appeals. A poster for the 69th New

\footnotetext{
${ }^{73}$ New York Muster Roll Abstracts of John Meehan, accessed at ancestry.com, November 23, 2019.

${ }^{74}$ Dependent Mother's Pension File of John Gannon, 26th New York Infantry, accessed at fold3.com, November 23, 2019.

75 9th Massachusetts Infantry Recruitment Poster, “The Glorious 9th! Irishmen to the Rescue! Irish Americans of Massachusetts!," 1862, (Massachusetts Historical Society).
} 
York State Militia called for Irishmen to join the "gallant corps" and reminded the volunteers of their ethnic heritage with a green harp surrounded by shamrocks (Figure 3).

Regimental songs and poems sung by Irish Regiments also helped create ethnic unity in the army. Although Irish units in the Union enjoyed the popular war songs like "Battle Cry of Freedom," "John Brown's Body," and "May God Save the Union," they also chose to express their ethnic heritage through lyrics. A popular song of the Irish Brigade referenced the dual loyalty to America and Ireland when the men sang,

We've never swerved from our old green flag, / Upbourne o'er many a bloody plain; / 'Tis now a torn and tattered rag, / But we will bear it proudly oft again. / We'll raise it high, this dear old flag, / From Liffey's banks to Shannon's stream, / "Till victory o'er the pirate rag / Upon our sacred cause shall beam....

We miss full many a comrade's smile, / The grasp of many a friendly hand, / We mourn their loss, and grieve the while / They had not died for fatherland. / But o'er their fresh and gory graves- / We swear it now, and evermore- / To free green Erin, land of slaves, / And banish tyrants from her shore. / Hurrah! hurrah! etc.

Now we're pledged to free this land, / So long the exile's resting-place; / To crush for aye a traitorous band, / And wipe out treason's deep disgrace. / Then let us pledge Columbia's cause, / God prosper poor old Ireland too! / We'll trample on all tyrant laws: / Hurrah for the old land and the new. / Hurrah! hurrah! etc. ${ }^{76}$

Poems written to mourn the loss of Irish soldiers similarly pointed to ethnic heritage and captured the devastation felt by Irish American communities throughout the North and abroad.

The Irish American newspaper reprinted the solemn words in the spring of 1863:

Here hath many a noble son, / Of trodden mother land, / Whose joy thro' life, / Was hope of strife. / For their love of native land.

They came from Carlow's fertile plains, / And Wexford's woody vales, / From Innisbowen, / And green Tyrone, / And Wicklow's hills and dales.

They came to seek amid the free, / Homes to reward their toil, / In which to see / That Liberty / Unknown on Erin's soil.

\footnotetext{
${ }^{76}$ Conyngham, The Irish Brigade and its Campaigns, 187-188.
} 
And well they loved the chosen land; / When menaced was her might, / Each grateful heart / A willing part / Took in her cause to fight.

And here they lie in unblessed earth, / No kindred eye to weep; / Far, far way, / From the abbey's grey. / Where their sires and grandsires sleep.

Oh! many a matron, many a maid, / Mourn in their native isle, / For the dear ones here, / Who no more shall cheer / Their hearts by their gladsome smile.

In many an ancient chapel there, / Nestled on the green hill side, / Will the good priest pray, / On the Sabbath day, / For his boys who in battle died.

Let us offer too, our orisons, / For each of the martyr band, / Who nobly gave / Their lives to save / The might of their adopted land. ${ }^{77}$

While Irish Americans fought and died for the Union, popular songs and poems of their units stood as constant reminders of the disaporic Irish identity they all shared.

Irish service to the Union and the early actions of Irish regiments helped sway nativist sentiment that was common before the war. During the 69th's time at Georgetown, Protestant men in a New England regiment visited the Irishmen and Harper's Weekly happily reported, "The common danger appears to have made native and foreigners common friends." ${ }^{78}$ Positive opinions of the Irish continued thanks to the successful contributions of the 69th New York at the Battle of First Manassas. Irish efforts here proved to native-born Americans that Irish soldiers could serve their adopted country bravely and loyally. In July 1861, Union commander Irvin McDowell organized his 30,000 troops and attacked Confederate General P.G.T. Beauregard's 20,000-man army at Manassas Junction, Virginia. Corcoran's 69th New York Infantry saw action near the Stone Bridge. In the afternoon, the 69th was ordered forward towards Henry Hill, and after failed attacks by other Union regiments, Sherman ordered Corcoran's men into battle. ${ }^{79}$ Although the Battle of First Bull Run ended in Union defeat and Colonel Corcoran was taken

\footnotetext{
${ }^{77}$ McCarter, My Life in the Irish Brigade, 232-232; reprinted in the Irish American, May 2, 1863.

${ }^{78}$ Harper's Weekly, June 1, 1861.

79 John J. Hennessy, The First Battle of Manassas: An End to Innocence, July 18-21,1861, rev. ed. (Mechanicsburg, PA: Stackpole Books, 2015), 67, 114-118.
} 
prisoner, the actions of the Irish 69th were honored in the native-born and Irish-American newspapers. Harper's Weekly described the attack when it said the New York Irish "dashed into the enemy with the utmost fury." ${ }^{\circ 0}$ The Irish American reveled in the actions of their Irish soldiers. They proudly reported that, "All accounts agree that the New York City regiments behaved admirably." They went farther saying, "above and before all, the 69th, under the lead of the brave Corcoran, the lamented Haggerty, and our lion-hearted Meagher, covered themselves with immortal glory." ${ }^{\prime 81}$ This reversal in nativist sentiment may have been due to the large numbers of Irish Americans who showed their support to the United States by fighting for the Union. Although they still maintained ties to their ethnicity, Irish Americans demonstrated their American identity, which positively impacted the way native-born Americans viewed the ethnic group.

The actions of Corcoran's New York Irishmen at First Manassas inspired other Irish Americans to join the United States Army. On August 10, the New York Irish American reprinted a note sent to Thomas Francis Meagher. "The glorious example set to the Irish adopted citizens by the galiant 69th, induced the formation of the $3 \mathrm{~d}$ Irish Volunteers" stated the paper. Like Corcoran and Meagher, the author of the letter hoped that when the "Irish perform a brave act, let them get the credit of it." ${ }^{82}$ This is a clear example of how the actions and service of the 69th New York Infantry created ethnic unity and pride for Irish Americans across New York and elsewhere in the North. Irish ethnic identity only grew in intensity as the war progressed, and New York Irishmen were often at the heart of this.

The losses at Bull Run did not diminish the enthusiasm of the Irishmen of the 69th New York State Militia, which led to the creation of the famous Irish Brigade. Even before they were

\footnotetext{
${ }^{80}$ Harper's Weekly, August 10, 1861.

${ }^{81}$ Irish American, August 3, 1861.

${ }^{82}$ Irish American, August 10, 1861.
} 
due to be mustered out on August 3, 1861, the officers planned to reorganize the regiment for three years' service. The Lincoln administration supported this idea and at the end of August, the War Department gave Colonel Thomas Francis Meagher permission to reorganize the unit into the 69th New York Volunteers. Meagher was also given the order to recruit four more regiments and form a brigade. Meagher quickly went to work, recruiting Irishmen from communities in New York, Pennsylvania, and Massachusetts. The Boston regiment was to be the 28th Massachusetts commanded by Colonel Matthew Murphy, and the Irishmen of Philadelphia rushed to form a similar regiment. In New York City, the 3rd Irish Volunteers, under the command of Colonel Felix E. O'Rourke, joined the brigade as the 63rd New York Infantry. The 69th New York joined the brigade under the command of Colonel Robert Nugent and the 88th New York joined shortly after. ${ }^{83}$

Home front support for newly enlisted Irish soldiers was strong among the New York Irish communities and was inextricably connected to their ethnic consciousness. Charitable contributions from individuals and societies and support of ethnic soldiers' families were specifically attuned to the needs of Irish soldiers over northerners in general. By the end of April 1861, groups such as New York's Union Defense Committee were created to support the families of 90-day servicemen. Even with the formation of these groups, New York's Irish Americans received direct and from their communities. After a month of service, hundreds of dollars had been raised for the families of the 69th New York State Militia, and on the 9th of May, a formal committee was established in the city to aid the Irishmen's families. However imperfect these relief agencies were, they provided vital assistance to poor Irish immigrant families that helped sustain them in America. Even after the Federal pension system was created

\footnotetext{
${ }^{83}$ Conyngham, The Irish Brigade and its Campaigns, 25-27.
} 
in 1862, these small relief committees helped sustain New York Irish ethnicity and exemplified public displays of specifically Irish support for the war.

In August 1861, Irish Americans gathered in mass to honor the fallen Irish heroes of First Manassas, and Thomas Francis Meagher used the occasion to recruit men for the newly formed Irish Brigade. Tens of thousands of Irish immigrants took part in a "Monster Irish Festival" on Manhattan to benefit the widows and orphans of Irish men who fell at Bull Run. The Committee of the Convention of Irish Societies organized the event. The Committee was composed of delegates from multiple interest groups such as Irish benevolent societies, the Ancient Order of Hibernians, abstinence societies, Irish militia companies, Catholic societies, and Irish worker's protective unions. ${ }^{84}$ The event was wildly popular with crowds estimated between 30 and 60,000. The New York Times reported that, "Everything edible or palatable was proffered with a delicate Hibernian reference to the gallant Sixty-ninth, and a hint that the exigencies of Bull Run demanded its immediate purchase. ${ }^{\circ 55}$ Meagher spoke to the massive crowd of Irish Americans and told of the sacrifices made at Manassas. However, he asked the audience to continue the fight when he said, "For my part, I ask no Irishman to do that which I myself am not prepared to $d o$. My heart, my arm, my life is pledged to the national cause, and to the last it will be my highest pride, as I conceive it to be my holiest duty and obligation, to share its fortunes." ${ }^{86}$ For Meagher and other Irish Americans, the festival in New York had a duel purpose: to raise money and honor the Irish fallen from Manassas, and recruit more Irishmen for the new ethnic Brigade. This public display of Irish support organized by specifically Irish aid societies demonstrated the important role ethnicity played in New York in the Civil War Era.

\footnotetext{
${ }^{84}$ Irish American, August 24, 1861.

${ }^{85}$ New York Times, August 30, 1861.

${ }^{86}$ Cavanagh, Memoirs of General Thomas Francis Meagher, 415 (emphasis in original).
} 
Meagher looked at Boston to recruit Irishmen for his brigade but he and the organizers had trouble filling the unit. The recruiters lacked sufficient numbers of Irishmen to muster the regiment into service until December, and even then they added companies in the field ${ }^{87}$ This early struggle to recruit Irishmen is something scholars have failed to recognize. Historians like Ella Lonn, in Foreigners in the Union Army and Navy, and William Burton, in Melting Pot Soldiers, argue that there was a rush of foreigners to Union service in an attempt to prove their loyalty to America. In actuality however, ethnic units sometimes struggled to fill their ranks as early as August 1861 . This revelation may also indicate a class divide between the Irish community. While upper class Irish Americans such as Corcoran or Meagher sought to form Irish units to train for a future war against England, Irish Americans of the lower classes were more interested in supporting their families in America and Ireland.

Despite recruiting difficulties, Meagher attracted sufficient numbers to muster the regiments of his new Irish Brigade into service and send them to Fort Schuyler, along Long Island for training. As the three New York regiments prepared to depart, a ceremony was held on November 18, 1861, to present the men with their regimental colors. Speakers present reminded the men of their historic role as soldiers in an Irish Brigade. Irish-American Judge, Charles Patrick Daly reminded the men of their lineage when he stated that the previous Irish Brigade, "achieved its historical renown not through the admitted bravery of its members merely, but chiefly by the perfection of its discipline." He warned the men to uphold their duty because "The selection of such a name only renders the contrast more glaring in the event of inefficiency and

\footnotetext{
${ }^{87}$ James L. Bowen, Massachusetts in the Civil War, 1861-1865 (Springfield, MA: Clark W. Bryan \& Company, 1889), 419.
} 
incompetency. ${ }^{" 88}$ For Daly and the others in attendance, Irish ethnicity was critical to how they understood their identity, and military service to the United States only helped to highlight this.

Know Nothing Politics and nativist rhetoric impacted the lives of Irish Americans in the United States and affected their experiences during the first year of service in the Civil War. While many soldiers chose to volunteer in non-ethnic regiments, many chose to enlist with their fellow Irishmen. Ethnic regiments appealed to Irish immigrants and their treatment and experiences were critical to how Irish Americans perceived and understood the Civil War. As the conflict progressed, New York Irish communities began to question their place in the Union due to how their soldiers were treated by native-born Americans. Throughout the Civil War, ethnic consciousness was strengthened through ethnic and non-ethnic regiments, the Irish American press, and the treatment of prominent Irish Catholics. Although tensions towards the war would only intensify throughout 1862 and 1863, fissures existed before this point and New York Irish Americans reconciled and dealt with them through their ethnic identity. Recognizing these early fissures in Irish support for the Union allows historians to understand the importance of ethnicity and the emergence of Irish multiculturalism in the United States.

${ }^{88}$ Conyngham, The Irish Brigade and its Campaigns, 31. 


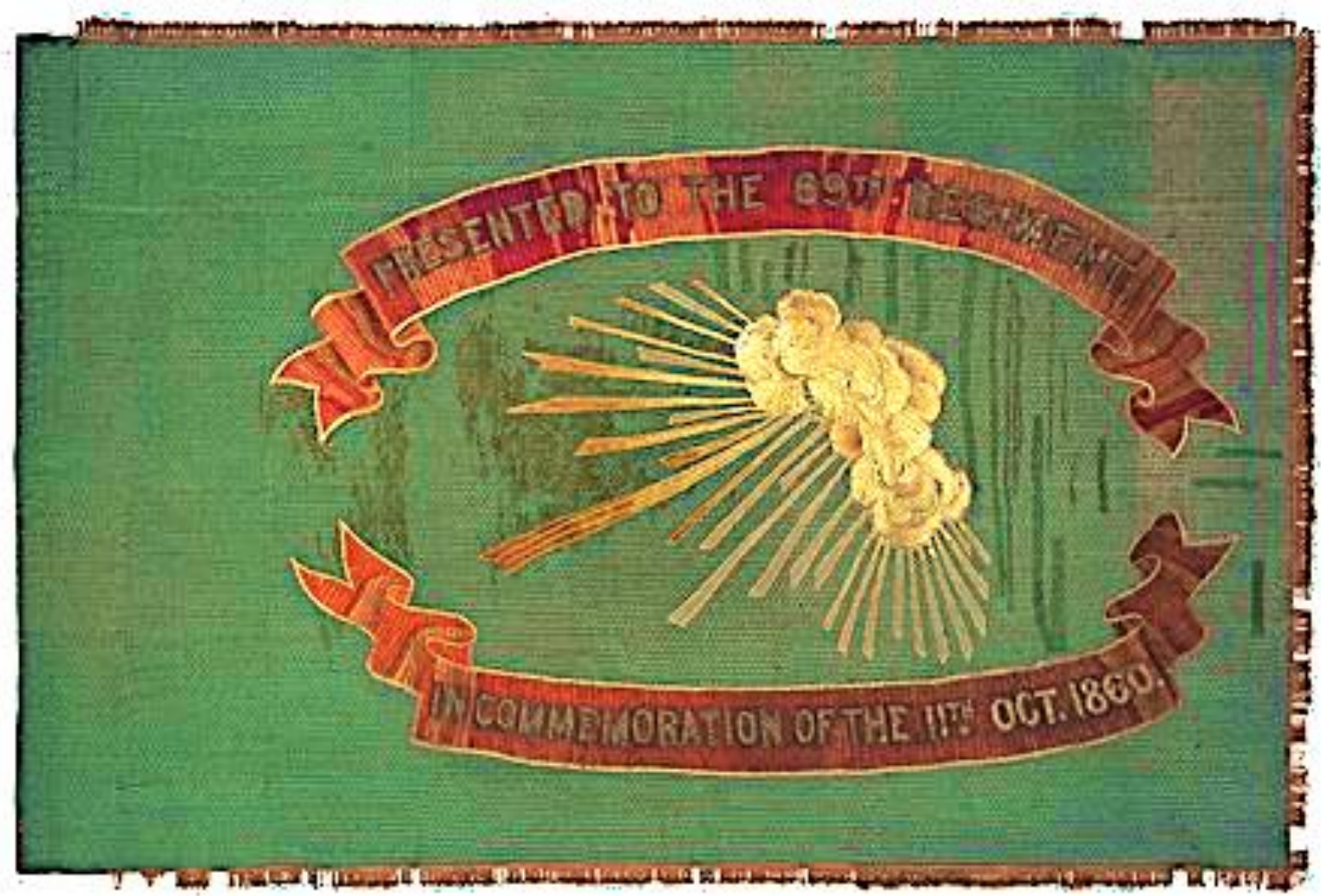

Figure 1: In March 1861, the regiment received this flag, known as the "Prince of Wales" flag. The green silk flag proudly included the Fenian sunburst with an inscription commemorating the day the regiment performed the disobedient act against the Prince of Wales (New York State Military Museum). 


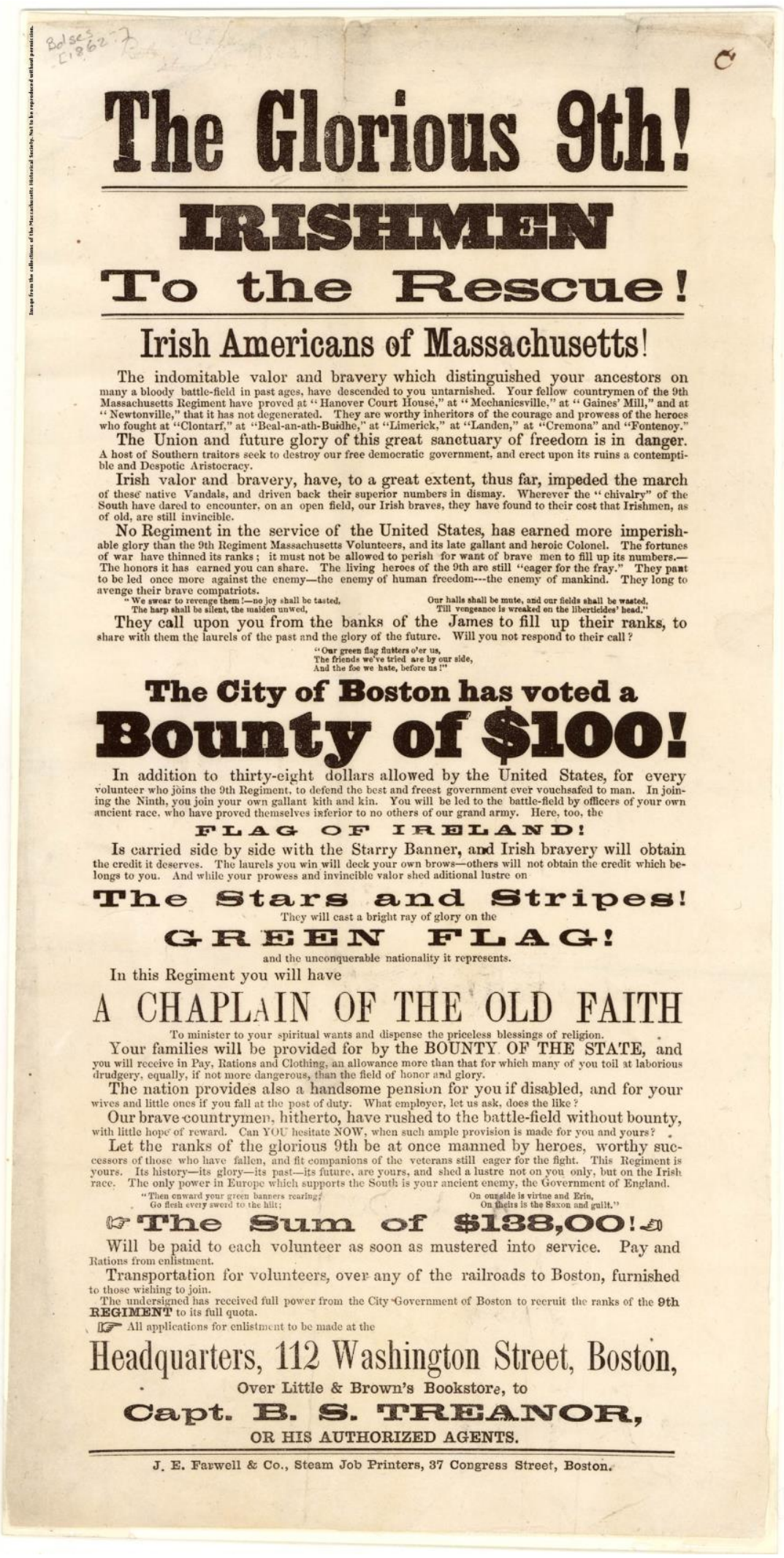

Figure 2: 9th Massachusetts Infantry Regiment Recruitment Poster (Massachusetts Historical Society). 


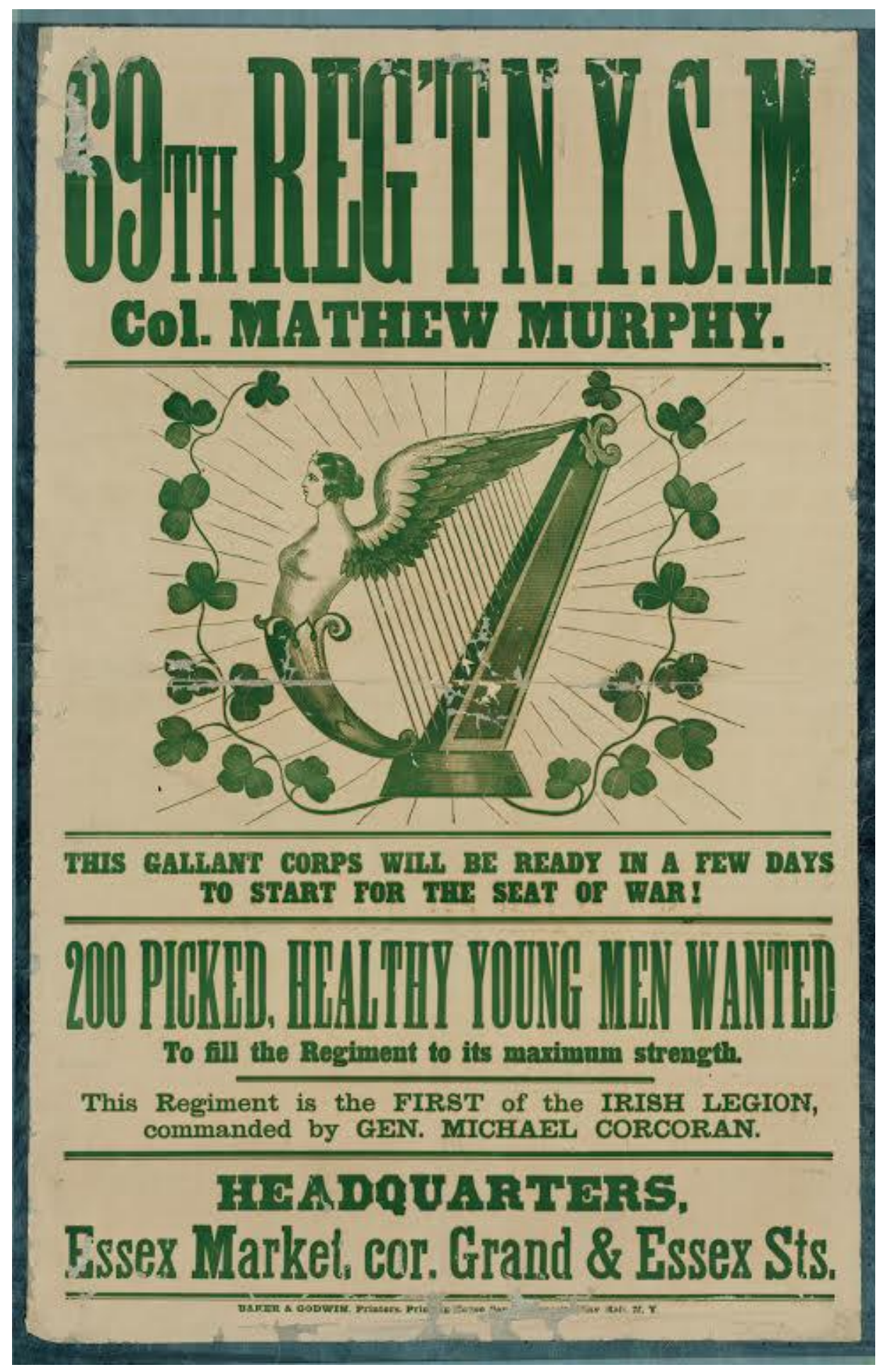

Figure 3: 69th Regiment N.Y.S.M. Recruitment Poster (New York Historical Society Museum \& Library) 


\section{Chapter II}

"Slaughtered like sheep:" Ethnicity, the Irish Brigade, and the Decline of Irish Support for the War in 1862

Although many Irish Americans were starting to question their place in the Union war effort, military and political decisions throughout the fall of 1862 only intensified this uncertainty. The hard fighting and great loss of life of the Irish Brigade at the battles of Antietam and Fredericksburg left the morale of the Irish-American community at an all time low. President Lincoln's decision to remove General George B. McClellan from command of the Army of the Potomac only increased the disillusionment among Irish communities of the New York and elsewhere. But the biggest blow to Irish morale came with the issuance of the Emancipation Proclamation, which led many Irish Americans to abandon the Union war effort for good. The second year of the Civil War brought drastic changes for all in the United States, and it also marked the height of Irish disillusionment. Sections of the country were already losing support for the President, and Irish Americans were among the first of this group to begin questioning the Union's war policy. Through the tumultuous year of 1862, Irish Americans in New York rallied behind the Irish Brigade and embraced their Irish ethnic identity in the midst of continued attacks against their Catholic faith and immigrant background.

After training that winter, General Thomas Francis Meagher and his Irish Brigade prepared to enter the war in the spring of 1862. As the fighting began in Virginia, General George B. McClellan planned to outflank Joseph E. Johnston's Confederate Army with an amphibious landing at Yorktown and march his men up the James Peninsula to seize the Confederate capital of Richmond. During the fighting of this Peninsula Campaign, the Irish Brigade and many other men in the Army of the Potomac experienced some of their first 
fighting. The unit racked up serious losses during the battles of Fair Oaks, Gaines Mill, and Malvern Hill, but it also earned the Irish Brigade an impressive fighting reputation. ${ }^{1}$ One soldier wrote after the fighting that, "the hillside is covered with the dying and the dead of the Irish Brigade."2

Following the battle at Fair Oaks, the 29th Massachusetts Infantry joined the Irish Brigade. The Irish 28th Massachusetts Infantry was initially meant to reinforce the Irish Brigade and not the 29th. However, the 28th Massachusetts was mustered up to strength sooner and was dispatched to serve under General Benjamin Butler in the Carolinas, which left the Protestant 29th Massachusetts to join the Irish Brigade instead. ${ }^{3}$ One member of the regiment recalled that General Meagher planned to welcome the men with a speech about their shared Irish military traditions but he quickly had to edit his speech. One man stated, "the Twenty-ninth was essentially an American regiment, very largely composed of and officered by men who were direct descendants of the early settlers of the Plymouth and Bay colonies..." ${ }^{4}$ The fighting and loss of the Irish Brigade continued through June and carried into July, during a series of engagements known as the Seven Days’ Battles. Staff officer Captain David P. Conyngham recalled that "Both armies were desperately cut up" but "the loss of the [Irish] Brigade during these fearful seven days was large both in officers and men.” During this time, the Brigade's

\footnotetext{
${ }^{1}$ For a more detailed look at the fighting during the Peninsula Campaign and the Seven Days see Brian K. Burton, The Peninsula and Seven Days: A Battlefield Guide (Lincoln, NE: University of Nebraska Press, 2007); Gary W. Gallagher, The Richmond Campaign of 1862: The Peninsula and the Seven Days (Chapel Hill: University of North Carolina Press, 2000); and Stephen W. Sears, To the Gates of Richmond: The Peninsula Campaign (New York: Ticknor \& Fields, 1992).

${ }^{2}$ David Power Conyngham, The Irish Brigade and its Campaigns (Glasgow: R \& T Washbourne, 1866), 106.

${ }^{3}$ Thomas Wentworth Higginson, Massachusetts in the Army and Navy During the War of 1861-1865 (2 vols.; Boston: Wright \& Potter, 1895-1896), 1:248.

${ }^{4}$ William H. Osborne, The History of the Twenty-ninth Regiment of Massachusetts Volunteer Infantry in the Late War of the Rebellion (Boston: A. J. Wright, 1877), 142.
} 
casualties were counted at approximately 700 officers and men, while the Army of the Potomac counted its losses at $15,249 .^{5}$

In the weeks that followed, General Thomas Francis Meagher returned home in an attempt to recruit Irishmen for his dwindling brigade. On July 25, 1862, he spoke to a massive crowd of Irish Americans at the 7th Regimental Armory in New York City. As Meagher stood in front of the green Irish flag on one side and the American flag on the other, the eloquent speaker recounted to the audience the brave and noble deeds accomplished by the Irish Brigade throughout the Peninsula Campaign. ${ }^{6}$ The 69th New York, who entered the Battle of Fair Oaks with 750 men, now stood 295 strong. The 88th New York lost 200 men, dropping its fighting capability to 400. The 63rd New York saw less fighting than the other two regiments but still saw its ranks reduced to 500 men. $^{7}$ Meagher then told the crowd that he needed 1,500 recruits to get his Irish Brigade up to its minimum strength. Large cheers erupted throughout the room as he insisted, "it should be the vehement desire and the intense ambition of every Irishman, who has one chord within him that vibrates to the traditions of that old lyric and martial land of his, not to permit its flag, so vividly emblematic of the verdure of its soil and the immortality of its faith, to be compromised in any just struggle in which it is displayed."8

Concerns over radical Republican abolitionists became more common among Irish Americans during this time because they felt they were contributing more than native-born men. Despite the exuberant response to Meagher's declaration, not all in attendance shared the same feelings. As abolition became a frequent topic of conversation, some Irishmen in the crowd felt the need to question Meagher's call for recruits by asking, "Why don’t the Black Republicans

\footnotetext{
${ }^{5}$ Conyngham, The Irish Brigade and its Campaigns, 217.

${ }^{6}$ Irish American, August 2, 1862.

${ }^{7}$ Robert G. Athearn, Thomas Francis Meagher: An Irish Revolutionary in America (New York: Arno Press, 1976), 114.

${ }^{8}$ Irish American, August 2, 1862.
} 
go?" An Irishmen from Brooklyn similarly recounted that "It would be well if Republicans had done their duty in this war as well as Irishmen, both as regards [to] enlisting and fighting." ${ }^{10}$ Irish Americans like Peter Welsh, who was a soldier in the Irish Brigade, demonstrated his support for the Democratic Party when he pointed to the faults of the Republican administration by stating in a letter home that "the imbecility of an incompetent administration and fanatical nigar worshippers" stand in the way "of puting a sucesfull termination to this acursed rebellion."11 While some in the audience shared similar thoughts, Meagher retorted saying, "Any man who makes a remark like that I denounce as a poltroon and coward. Because others shrink from their duty is no reason why you should shrink from yours." 12

Although the audience applauded his response, they still questioned how the Irish Brigade lost so many men that spring and wondered if it was done purposefully by nativists who supplied Anglo-American troops with better supplies. Likewise, disease and enemy fighting reduced the ranks of all in the Army of the Potomac and the Irish Brigade was no exception, but the New York Irish were all too familiar with nativism and felt that this may have been yet another example of animosity aimed in their direction. However, the general denied these rumors as well and explained Irish losses were not due to "insufficient food, or clothing, or undue labor, or neglect of any kind, or sickness," but rather by the hard fighting of the enemy. ${ }^{13}$

Meagher ended his speech by reminding his countrymen how important preserving American unity was for future Irish exiles. In closing, he asked those in attendance for "one more

\footnotetext{
${ }^{9}$ Irish American, August 2, 1862; Radical Republicans were a faction of the Republican Party and were distinguished for their fierce advocacy for the abolition of slavery. Some members of the group once belonged to the Know-Nothing Party, which added reason for Irish antipathy toward the faction.

${ }^{10}$ Irish American, October 11, 1862.

${ }^{11}$ Peter Welsh, Irish Green and Union Blue: The Civil War Letters of Peter Welsh, Color Sergeant, 28th Regiment, Massachusetts Volunteers, eds. Lawrence Frederick Kohl and Margaret Cossé Richard (New York: Fordham University Press, 1986), 70.

${ }^{12}$ Irish American, August 2, 1862.

${ }^{13}$ New York Times, July 26, 1862.
} 
effort, magnanimous and chivalrous, for the Republic, which, to thousands and thousands and hundreds of thousands of you has been a shelter, a home, a tower, of impregnable security, a pedestal of renown and a palace of prosperity, after the worrying, the scandals and the shipwreck that, for the most part, have been for many generations the implacable destiny of our race."14 Some Irish soldiers agreed with the general by highlighting their newly acquired American identity through enlisting to save the United States. "I owed my life to my whole adopted country," wrote private William McCarter of the 116th Pennsylvania Infantry, insisting that "its form of government, its institutions, [and] its Stars and Stripes" is what made him determined to enlist. ${ }^{15}$ Peter Welsh of the 28th Massachusetts Infantry also mirrored Meagher's words in a letter to his father-in-law who lived in Ireland. Welsh explained, "America is Irlands refuge Irlands last hope" and every Irishman in America has "a stake in the nation and an interest in its prosperity." ${ }^{" 16}$ Meagher understood the importance America played in the lives of Irish men and women and made sure he highlighted this in his speech. As he concluded, the New York audience erupted in a whirlwind of applause and appeared ready to answer his enlistment requests.

Although the Irish in the audience and others who read Meagher's speech in the papers seemed enthusiastic at first, Irish Americans questioned whether service to the Union was the best choice. Out of the reported four thousand in attendance, Meagher received only 120 recruits. While the Irishman pulled out many tricks to try and persuade men to join his ranks, recruiting was not the same as it was following the first Battle of Bull Run in July 1861. On top of this, twenty-three days before Meagher gave his speech, a call for 300,000 recruits for three years of

\footnotetext{
${ }^{14}$ Irish American, August 2, 1862.

15 William McCarter, My Life in the Irish Brigade: The Civil War Memoirs of Private William McCarter, $116 t h$ Pennsylvania Infantry, ed. Kevin O’Brien (Cambridge, MA: De Capo Press, 1996), 221.

${ }^{16}$ Welsh, Irish Green and Union Blue, 101-102.
} 
service went out. ${ }^{17}$ The failure of the Peninsula Campaign may have added to the lack of volunteers as well. For months the Army of the Potomac made great progress, making it to the gates of the Confederate capital of Richmond, all to be pushed down the peninsula in a matter of seven days. This blow to Union morale no doubt affected those interested in joining the ranks.

Similarly, by the spring of 1862, the fervor and excitement of war had passed, which caused enlistment numbers to decrease. "I am sick and tired of the war," wrote private William Dwyer of the Irish Brigade to his mother back in New York. ${ }^{18}$ John Doherty, a Corporal in the 63rd New York Infantry wrote home to his mother in July telling her he "hope[s] none of the boys will take it in to their head to list[,] for soldiering is not what it is cracked up to be."19 Irishman Peter Welsh explained that while "it is right and the duty of citizens and those who have lived long enough in this country to become citizens to fight for the maintainence of law order and nationality" he urged his brother to "never for heavens sake let a thought of enlisting in this army cross your mind" because "the country has no claim on you." 20 The Dublin Telegraph printed a similar warning to its readers in Ireland. "Dr. Cahill's Letters from America to the People of Ireland" urged his fellow countrymen "not to leave Ireland till the political affairs of this country shall have been satisfactorily and finally settled." ${ }^{.1}$ Messages like these contradicted the speech given by Meagher and attributed to the hesitation among the Irish American population in New York and elsewhere. Unlike Meagher and other Irish nationalists, these men were less willing to risk their lives for military training.

\footnotetext{
${ }^{17}$ Frank A. Doyle, A Party of Mad Fellows: The Story of the Irish Regiments in the Army of the Potomac (Dayton, OH: Morningside Books, 1996), 167.

${ }^{18}$ Civil War Widows' Pension of William Dwyer, 63rd New York Infantry, accessed at fold3.com, August 14, 2019.

${ }^{19}$ Civil War Widows' Pension of John Doherty, 63rd New York Infantry, accessed at fold3.com, April 23, 2019.

${ }^{20}$ Welsh, Irish Green and Union Blue, 155.

${ }^{21}$ Irish American, March 16, 1861.
} 
Even as Irish enlistment began to wane, Irish-American newspapers such as the Boston Pilot and the New York Irish American continued to highlight the achievements of Irish soldiers on the battlefields, which created a sense of unity among the ethnic group. Although each newspaper carried copious coverage of the national war news, Irish papers repeatedly singled out purely Irish contributions and included many letters written by Irish soldiers. On June 14, The Irish American explained, "the recent battle before Richmond has again demonstrated the superior military qualifications of the Celt." ${ }^{" 22}$ Stories like these, along with news from Ireland and Gaelic lessons, shows how editors of Irish papers pushed their readers to see themselves and their communities as Irish first and American second. ${ }^{23}$

The notion of "the fighting Irishman" was something Irish Americans were proud to highlight, and the ethnic group pointed to this idea countless times throughout the Civil War. The 69th New York Infantry's motto, "Remember Ireland and Fontenoy" was a reference to the bayonet charge made by the French army's brigade of Irish exiles, which helped secure victory over the British in 1745, and was a source of pride and honor to the Irish community in America. ${ }^{24}$ Irish soldiers have "instinctive perception" of military "duties, and can, therefore, soon acquire a knowledge of the most difficult company, regimental, or brigade drill and manoeuvres" proudly remarked David Conyngham of the Irish Brigade. ${ }^{25}$ General Meagher similarly referenced the Irishmen's "long ago established...reputation for fighting" as reason for

\footnotetext{
${ }^{22}$ Irish American, June 14, 1862.

${ }^{23}$ Major newspapers of the time represented the public consensus of their readerships. As Nicholas Marshall has shown, "readers could not help but be firmly connected to a national marketplace of political and cultural ideas" and the "dearth of new reading material in these areas created an intense focus on the weekly paper as a purveyor of fresh news, information, and culture." Because ethnic editors held great positions of power in their respective communities, they played a major role in how those community members viewed the world around them. See Nicholas Marshall, "The Rural Newspaper and the Circulation of Information and Culture in New York and the Antebellum North," New York History 88, no. 2 (Spring 2007): 140, 145-146. Also see William L. Joyce, Editors and Ethnicity: A History of the Irish-American Press, 1848-1883 (New York: Arno Press, 1976).

${ }^{24}$ Joseph G. Bilby, Remember Fontenoy!: The 69th New York and the Irish Brigade in the Civil War (Hightstown, NJ: Longstreet House, 1995), 3-5.

${ }^{25}$ Conyngham, The Irish Brigade and its Campaigns, 45.
} 
why his brigade was called upon so often. ${ }^{26}$ Irishman William McCarter of the 116th

Pennsylvania Infantry mirrored this belief in a letter, when he comically recalled others in his regiment stating: "Look...Bill's got his Irish up" after he began throwing apples at the window of a Southern women who insulted Union soldiers. ${ }^{27}$

References to hard-fighting Irish were common among native-born Americans as well, who sometimes highlighted the ethnic group in a positive way. Famous New York diarist George Templeton Strong wrote after the Battle of First Manassas that, "Corcoran's Irishmen are said to have fought specially well, and to have suffered much." ${ }^{28}$ Other native-born Americans who referenced Irish fighting did so with nativist undertones present. James Decker, a soldier in the 1st New York Light Artillery wrote about his guard duty experience, when he assisted in the imprisonment of an Irish soldier "who fought like a tiger," which caused "the sergeant [to] stuck the bayonet in him two or three times before he would yeald."29 Stereotypical views of the Irish were even more pronounced in the diary of a Union surgeon who wrote of the Irish Brigade saying, "the only man that really loves it [fighting], after all, is the green, immortal Irishman. So there the brave lads from the old sod, with the chosen Meagher at their head, laughed and fought, and joked, as if it were the finest fun in the world." 30

Even as some native-born Americans were impressed by the actions and record of the Irish Brigade in the early battles of the Civil War, other Anglo Americans denied the ethnic group credit and continued to perpetuate nativist rhetoric. Officer Josiah Favill proudly acknowledged the superiority of Irish soldiers, writing, "Nearly all of these fellows [in the Irish

${ }^{26}$ Irish American, August 2, 1862.

${ }^{27}$ McCarter, My Life in the Irish Brigade, 45.

${ }^{28}$ George Templeton Strong, Diary of the Civil War, 1860-1865, ed. Allan Nevins (New York: The Macmillan Company, 1962), 169.

${ }^{29}$ Private James E. Decker, 1st New York Light Artillery, Albany, New York, letter to Francis Decker, April 1, 1862, Bound Volume 418-01, Fredericksburg and Spotsylvania National Military Park Collections.

${ }^{30}$ Thomas T. Ellis, Leaves from the Diary of an Army Surgeon: Or, Incidents of Field, Camp, and Hospital Life (New York: John Bradburn, 1863), 54. 
Brigade] are courageous, and as I have many times observed natural-born soldiers.” Favill continued, "I would rather command a good regiment of Irishmen than any other I have ever seen." ${ }^{31}$ Sergeant George S. Gove of the 5th New Hampshire Infantry held a different opinion of Irish soldiers than the one expressed by Favill. Even though he acknowledged that the "Irish Brigade has done some hard fighting" Gove believed that their actions have "been puffed to the skies" and that they "are not reliable" and "they cant always be depended on." 32 Colonel Robert Gould Shaw of the 54th Massachusetts Infantry detested Irishmen and refused to acknowledge their accomplishments in service. In a letter home to his mother, Shaw stated that the AfricanAmerican soldiers in his regiment "learn all the details of guard duty and Camp service, infinitely more readily than the Irish I have had under my command."33

While the belief of the hard-fighting Irish was accepted by almost all and remained an important part of how Irishmen identified themselves, their deeds on the battlefield came at a cost. Irish Americans in the army and at home opened their papers to search for names of friends and loved ones who may have fallen victim to a rebel bullet. "It will be seen how largely the Irish element enters into the composition of the [dead members of the] corps" wrote one Irish paper. ${ }^{34}$ As Irish Americans at home learned that their sons and husbands had been killed or maimed in battle, they began to wonder if supporting the war was worth the cost. Letters like the one Mary Mooney, a resident of King's New York, received from her husband Felix told a different story than the one Meagher presented to the audience at his July 25 rally. As he was

\footnotetext{
${ }^{31}$ Josiah Marshall Favill, The Diary of a Young Officer Serving with the Armies of the United States during the War of the Rebellion (Chicago: R. R. Donnelley \& Sons Company, 1909), 284.

${ }^{32}$ Sergeant George S. Gove, 5th New Hampshire Infantry, Camp near Falmouth, Virginia, April 9, 1863, Bound Volume 557-02, Fredericksburg and Spotsylvania National Military Park Collections (The original letter is part of the Parsons Family Papers in the Milne Special Collections at the University of New Hampshire Library, Durham, $\mathrm{NH}$ ).

${ }^{33}$ Robert Gould Shaw, Blue-Eyed Child of Fortune: The Civil War Letters of Colonel Robert Gould Shaw, ed. Russell Duncan (Athens, GA: University of Georgia Press, 1992), 313.

${ }^{34}$ Irish American, July 12, 1862.
} 
recovering in a hospital in Newport News, Mooney wrote to his wife telling her how much he wishes "they would send me to New York Hospital so that you could come and see me before I die." 35 The casualty reports were felt transnationally as well. In late 1862, Eleanor Hogg, a resident of Roscommon, Ireland, received a letter from her nephew in New York informing her that both her son Pat and her husband Farrell died. "Deare ant i have two inform about a worst Newes Farrell listed in the Irish brigade that is the 88 regiment newyorke Volenteers" and was wounded "on the 29 of june and died of his wound..."36 These letters brought the stark reality of war to the home front and caused a shift in morale for both native-born and Irish Americans.

The large loss of life may have had a larger impact on the immigrant population of New York than it did on native-born Americans due to the fact that Irish Americans were new to the country. Irish Americans lacked a degree of loyalty and sense of belonging that was more natural to Anglo Americans who lived in the United States for generations. This is not to say immigrants were disloyal, but their loyalty was not as deeply rooted as that of native-born Americans, and the nativist prejudice they faced did not help. Only a few years prior, immigrants were targeted by the Know Nothing Party and as Irish-American casualties continued to rise during the war, their communities wondered if any of this would improve their condition in America.

Concerns over the treatment and safety of Irish loved ones in the Union service were compounded by the ethnic groups' belief of nativism at work. In March 1862, at the Battle of Kernstown, Irish-born Brigadier General James Shields inflicted a tactical defeat on Confederate General Thomas J. "Stonewall” Jackson during the Shenandoah Valley Campaign. The day after the battle concluded, Shields was promoted to major general, however the promotion was

\footnotetext{
${ }^{35}$ Civil War Widows' Pension of Felix Mooney, 61st New York Infantry, accessed at fold3.com, July 18, 2019.

${ }^{36}$ Civil War Widows' Pension of Farrell Hogg, 88th New York Infantry, accessed at fold3.com, September 14, 2019.
} 
withdrawn, reconsidered, and finally rejected ${ }^{37}$ This caused outrage among Irish communities. A letter reprinted in the Irish American on July 12 stated, "We believed he had attained his merited rank some months ago; but the announcement of this base ingratitude has almost paralyzed our confidence and enthusiasm, and suffused every Irish cheek of Iowa and the nation with a flush of indignant disgust. None have contributed more towards the number and efficiency of the Union army than the countrymen and admirers of Gen. James Shields." 38

Anger over Shields' rejection proved to many Irish Americans that their sacrifices for the Union had gone unappreciated by Anglo Americans. The letter printed in the Irish American united Irish east and west who argued that native-born Americans, "seem determined to cast a damper on the military patriotism of our people." A correspondent to the Irish American wrote on July 26 that is "the duty of every man... of Irish birth, to raise his voice, and say aloud and boldly, that the sacrifices, the noble enthusiasm, the indomitable courage, the precious blood and lives of our people, that have been lavishly offered up on the sacrificial altar of American constitutional freedom, have not been, are not, and never will be appreciated by the present government." Irish communities were urged to demand justice from native-born Americans by creating a "united voice of our people, from the Atlantic to the Pacific, to forego their narrow, Puritanic, Know-Nothing bigotry, and render justice to a brave soldier and an efficient and loyal officer, even though the blood of a Celt should flow in his veins." 39 As the news spread, "an almost universal feeling prevailed that injustice had been done to Shields because of his Irish standing. ${ }^{\$ 40}$

\footnotetext{
${ }^{37}$ Ezra J. Warner, Generals in Blue: Lives of the Union Commanders (Baton Rouge: Louisiana State University Press, 1964), 444-445.

${ }^{38}$ Irish American, July 12, 1862.

${ }^{39}$ Irish American, July 12, 1862.

${ }^{40}$ Irish American, July 26, 1862.
} 
With the pre-war nativism against Catholic immigrants so prominent, Irish soldiers and their families at home saw any slight towards their soldiers as an aggressive attack on their ethnic identity. One Irishmen explained, "we feel that we are suffering gross injustice from the fact, that 150,000 brave volunteers of Irish birth, in arms for the Constitution, are not properly represented, having but two Brigadier Generals out of the 200 on the muster roll of the United States, while the rank and file, admittedly, number fully one-fourth of the army." ${ }^{41}$ Another Irish-American soldier was infuriated over the "slanders of some of the soldiers are trying to circulate about Father Christy" because "It kills them to think that a Catholick' Priest should be the Chaplain." The seemingly blatant nativism towards General Shields was yet another factor that caused Irish Americans aggravation, with questions surrounding military aid and supplies to Irish soldiers also being a concern. Men like Generals Banks, McDowell, and Fremont, "whose military resources in every department except that of the brain-box seem to have been abundant," were given priority over Shields. ${ }^{43}$ This issue was no doubt on the minds of those in attendance at Meagher's July 25 speech in New York, and shows that newspapers like the Irish American were not exaggerating or overplaying the views of their readership.

For the Irish throughout the North, the perceived insult against Shields was yet another factor that caused the ethnic group to unite behind their ethnicity. Outrage over how General Shields was treated and the perceived injustice towards Irish soldiers in regards to supplies and aid were captured and spread through the Irish-American press. While these topics were scarcely mentioned in the native-born press, editors of Irish-American newspapers provided copious

\footnotetext{
${ }^{41}$ Irish American, July 26, 1862; by the end of the American Civil War, twelve Irishmen would reach the rank of Brigadier General in the United States Army but at the time of the complaints only Thomas Francis Meagher and Michael Corcoran held such rank. See Warner, Generals in Blue.

${ }^{42}$ Ron Gancas ed., Dear Teres: The Civil War Letters of Andrew Joseph Duff and Dennis Dugan of Company F, the Pennsylvania Seventy-Eighth Infantry (Chicora, PA: Mechling Bookbindery, 1999), 71.

${ }^{43}$ Irish American, July 12, 1862.
} 
coverage of these events, showing how Irish editors and readers were interested in distinctly Irish issues, especially those that dealt with supporting Irish soldiers. This continued ethnic focus, which lasted throughout the Civil War, enhanced ethnic consciousness and overall unity among Irish Americans.

Yet even with all these complaints, possibly the most important insult that unified Irish Americans was the seemingly anti-Catholic hatred seen in the army. The New York Irish American claimed that several Catholics "died, calling for a priest," because the Catholic Chaplain was refused admission to administer the last rights. ${ }^{44}$ While this is likely untrue, Irish worries regarding religion were grounded. Out of the approximately 200,000 Catholics that served in the Union Army, only approximately fifty-three priests served in regiments or hospitals. For nineteenth-century Catholics, only priests could provide important sacraments such as Holy Communion, Penance, and Anointing of the Sick, which were crucial to salvation in the minds of these individuals. ${ }^{45}$ Due to the lack of Catholic priests in the army, religion was a constant concern for Irish Catholics in Union service.

Some Catholic soldiers made do by reading the scriptures or turning to devotional scapulars to remind them of their commitment to Christianity but it seems that concerns over whether the Catholic faith could be properly practiced in the army may have affected recruitment for Irish Americans as well. William Dwyer of the 63rd New York Infantry asked his mother to send him a scapular that she could "buy in any Catholic Book Store" and "get it blessed by the priest." 46 While this was a popular substitute, most Catholic soldiers preferred to have a priest present to celebrate the sacraments. "What a terrible fate it would be to die on the battle field and

\footnotetext{
${ }^{44}$ Irish American, July 26, 1862.

${ }^{45}$ William B. Kurtz, Excommunicated from the Union: How the Civil War Created a Separate Catholic America (New York: Fordham University Press), 68-70.

${ }^{46}$ Civil War Widows' Pension of William Dwyer, 63rd New York Infantry, accessed at fold3.com, August 14, 2019.
} 
be thrown into a hole like a dog, no priest perhaps, no friends" worried Irish American Hugh Harlin. ${ }^{47}$ An Irishmen in the 78th Pennsylvania Infantry also highlighted the importance he put on his Catholic faith. "[Father] Christy is with us here. I have not went to my [religious] duty since I left. You cannot imagine how rejoiced I was when I seen him come on the boat at Louisville. ${ }^{\prime 48}$ These men provide an interesting insight into how important the role of religion played in the daily lives of Irish Catholics in the nineteenth century.

Catholic priests served almost exclusively in Catholic regiments so the shortage of priests was mitigated somewhat by long encampments, which allowed Catholic chaplains to circulate among different regiments and administer to the needs of the men of the Catholic faith. William C. White of the 69th Pennsylvania Infantry wrote while camped at Bolivar Heights that although "there is no priest with us here, but there is one [that] comes from the Irish Brigade and says Mass every Sunday." 49 For Irishmen in regiments where Catholics were the minority, concerns over the reluctance of Protestant officers to accept a priest as a chaplain was another reason for Catholic soldiers to enlist in regiments such as the Irish Brigade. Throughout the entire Civil War, the Irish Brigade had at least one priest to administer to its men. Father William Corby acknowledged that when men in the army needed the services of a priest, even "during the active campaign... [they] directed their steps to the Irish Brigade, where they were sure to find one."50

The presence of priests in the field helped sustain Catholic identity and interest among Irish soldiers. During the Civil War, the selection of chaplains rested largely with the churches because the federal government set few qualifications for chaplains other than they be "a

\footnotetext{
${ }^{47}$ Quoted in Susannah Ural Bruce, The Harp and the Eagle: Irish American Volunteers and the Union Army, 1861 1865 (New York: New York University Press, 2006), 108.

${ }^{48}$ Gancas, Dear Teres, 15.

${ }^{49}$ William C. White, 69th Pennsylvania Infantry, Camp on Bolivar Heights, October 5, 1862, 69th Pennsylvania Infantry Vertical File, Antietam National Battlefield Collection.

${ }^{50}$ William Corby, Memoirs of Chaplain Life: Three Years Chaplain in the Famous Irish Brigade in the Army of the Potomac, ed. Lawrence Kohl (Chicago: La Monte, O’Donnell Printers, 1893), 21.
} 
regularly ordained minister of some Christian denomination" and have the endorsement of an authorized ecclesiastical body. ${ }^{51}$ Congress and the War Department left definitions of the chaplain's responsibilities to the church and the soldiers of his regiment. The principal duty of Catholic chaplains was to hold worship services and administer the sacraments. One of the most important of these tasks was the arrangement of Sunday Mass. The constant movement of the armies often interrupted these efforts, however priests did what they could to attend to their followers. ${ }^{52}$ During the Peninsula Campaign, "Mass was celebrated in the forest of Virginia" after soldiers of the Irish Brigade split timber logs to create "the rudest of altars" for their chaplain. "I "I had the pleasure of hearing Mass this morning for the first time since I left home" wrote private Joe Duff. He somewhat comically continued by saying, "the altar was an old table, two candles, and a crucifix. I thought that if you and Sarah was their, things would be fixed up in a neater manner." ${ }^{, 54}$ Even with the uncertainty that came with war, Catholic chaplains remained faithful to their duties and made every attempt to administer to their soldiers.

Although life of an army chaplain was often dangerous, Catholic soldiers took great pride in the duty and sacrifices of their priests in battle. Catholic priests risked their lives to tend to their wounded men. During the Seven Days Campaign, Fathers Dillon and Corby of the Irish Brigade came under fire during the Battle of Fair Oaks. As Corby stopped to hear a wounded man's confession behind a small house, he likened the sound of the bullets hitting the structure to hailstones on a tin roof. Corby proudly recalled years later "as fast as our men dropped, they

\footnotetext{
${ }^{51}$ Gardiner H. Shattuck, A Shield and Hiding Place: The Religious Life of the Civil War Armies (Macon, GA: Mercer University Press, 1987), 54.

${ }^{52}$ Randall M. Miller, "Catholic Religion, Irish Ethnicity, and the Civil War," in Religion and the American Civil War, ed. Randall M. Miller, Harry S. Stout, and Charles Reagan Wilson (New York: Oxford University Press, 1998), 265-267.

${ }^{53}$ Corby, Memoirs of Chaplain Life, 37-38.

${ }^{54}$ Gancas, Dear Teres, 30.
} 
were seen first by the priest." ${ }^{, 55}$ A staff member of the Irish Brigade similarly wrote that their Catholic chaplains "never left the field while they had a duty to perform, but cheerfully allowed themselves to fall into the enemy's hands sooner than neglect the spiritual or temporal welfare of our brave sufferers." 56

Ultimately there were not enough priests to administer to Catholic soldiers, so nuns also played a critical role in the lives of Irish-American soldiers in the Union Army. Scholars of Civil War nurses have often highlighted how the conflict was a watershed moment for women expanding their role in the public sphere and giving them the opportunity to challenge the traditional gender norms of the nineteenth century. While serving as a nurse was a new experience for most women, many nuns from the Daughters of Charity were well trained in caring for the sick. The Daughters of Charity are an order of Catholic nuns first formed in France and their first community in America was founded in Emmitsburg, Maryland in 1809. These women were eager to serve as nurses, with around one-third of the approximately 650 Catholic nuns who served in the Civil War coming from the Emmitsburg Community of the Daughters of Charity ${ }^{57}$ Of these sister nurses, nearly fifty percent were born in Ireland and saw their role in the war as a way to save the body and soul of their patients rather than assert new rights for women. ${ }^{58}$

Even though the Irish nuns from the Emmitsburg Community played a critical role in treating wounded soldiers' bodies and souls, many experienced prejudice due to the fact that they were Catholic women. While serving at a United States military hospital in Frederick Maryland,

\footnotetext{
${ }^{55}$ Corby, Memoirs of Chaplain Life, 72-76.

${ }^{56}$ Conyngham, The Irish Brigade and its Campaigns, 111.

${ }^{57}$ Jane Shultz, Women at the Front: Hospital Workers in Civil War America (Chapel Hill: University of North Carolina Press, 2004), 261.

${ }^{58}$ Of the 170 known nuns form the Emmitsburg Community that served in the Civil War, seventy-three of them were born in Ireland. "Sisters of Charity who Nursed During the Civil War," Daughters of Charity Provincial Archives, Emmitsburg, Maryland.
} 
the Daughters of Charity complained that Protestant ladies of the area treated them badly and "embittered the patients minds against us..." Caring for the soul of the soldiers was sometimes more important than care to their wounds because it was a way for the sister nurses to serve God. The surest sign that they were doing God's will was through baptizing men and bringing them into the Catholic faith. While serving at Hammond Hospital in Point Lookout, Maryland, the Daughters of Charity were chastised by members of the female army nursing corps, who were "as hostile to Catholicy, as were the North \& South to each other." Surgeons at Point Lookout embraced this animosity towards the Daughters of Charity as well. One doctor, who was also a Protestant minister, was enraged to hear that one of his patients was baptized by a sister nurse even though the wounded soldier requested it. ${ }^{59}$ Even as these women embraced their identity as Americans by supporting the Union as nurses, they continued to be discriminated against because of their ethnic identity as Irish Catholics. ${ }^{60}$

The growing feeling among Irish Americans that they were being asked to sacrifice too much for native-born Americans who did not appreciate their efforts caused the ethnic group in New York to unite, look inward, and push for greater rights in their adopted country. This also contributed to the diminishing support Meagher witnessed in the days following his recruiting speech in New York. Because of this, he requested and received an extension on his leave to continue his efforts. Along with the nativism Irish Americans felt against them, Meagher contributed the lacking support to Radical Republicans within Lincoln's party. ${ }^{61}$ The civilian job market saw an improvement at this time as well, which caused many Irishmen to agree that the

\footnotetext{
${ }^{59}$ Notes of the Sisters' Service in Military Hospitals 1861-1865, 168, Daughters of Charity Provincial Archives, Emmitsburg, Maryland.

${ }^{60}$ While most historians focus on the agency women acquired due to the new roles as nurses during the American Civil War, few have looked into the ethnic and religious differences among these women. Through looking at the Daughters of Charity, one can see how their experiences during the Civil War were shaped not only by their gender but also by their ethnic identity.

${ }^{61}$ Athearn, Thomas Francis Meagher, 115.
} 
minimal bounties offered by Meagher and the government were not enough to risk their lives. This provides another example of how the goals among members in the Irish-American community may have differed depending on their class standing. Meagher's lack of support may have also been linked to the recent release of Irish nationalist and beloved general Michael Corcoran from a Confederate prison. While Meagher was attempting to gain volunteers for his Irish Brigade, Corcoran began to recruit Irishmen for his unit, "Corcoran's Legion."

Like Meagher, Corcoran was focused once more on uniting Irish Americans in support of the war and planned to recruit an Irish Brigade rather than accept command of a non-ethnic unit. Corcoran acknowledged the tremendous sacrifice already made by Irish Americans when he explained, "I do not press my Irish fellow citizens to enlist because I think they have not done enough. I believe they have done their share; but the country is in danger, and at such a time let us not be comparing differences with each other." The Irishman argued that nativist attacks should be ignored when he told his fellow countrymen,

I have one word more...not to allow a petty malice, or anything you may have suffered at the hands of individuals, from time to time, either here [in New York] or in any other State, to interfere with the sacred duty and obligation you owe to the flag. Let the politicians, who have been using us long enough, stay at home, if they will, but let us go and fight the battles of the nation, and when we come home a grateful nation will extend to us sufficient to meet all our wants. ${ }^{63}$

In this speech, Corcoran attempted to appeal to the Irishmen in the crowd by arguing that their service to the Union would cause native-born Americans to appreciate them.

In September, the Union and Confederates clashed again near Antietam Creek outside the town of Sharpsburg, Maryland. This battle would be remembered as the bloodiest single day in American history, ending with more than 22,000 soldiers killed, wounded, or missing. Irishmen took part in some of the heaviest fighting seen by the Union Army at Antietam. The fighting in

${ }^{62}$ Bilby, Remember Fontenoy!, 50.

${ }^{63}$ Irish American, August 30, 1862. 
the West Woods devastated the ranks of the Irish 69th Pennsylvania, with a total loss of 88 killed, wounded, or missing. ${ }^{64}$ One Catholic soldier wrote that seeing the battlefield made him sick because "It was worse than Fair Oaks" and "the dead lie all along." 65

Meagher's Irish Brigade also suffered horribly, charging the Sunken Road, which was later coined by many as the "Bloody Lane." As the men of the Irish Brigade neared the Sunken Road, Father William Corby performed a hasty absolution and waited for his services to again be needed by the wounded and dying. ${ }^{66}$ In twenty or thirty minutes after the absolution, Corby recalled that, "506 of these very men lay on the field, either dead or seriously wounded." 67 The 63rd and 69th New York regiments of the Irish Brigade lost the highest percentage of men of the Union side, suffering fifty-nine percent and sixty-two percent respectively. ${ }^{68}$ The 88 th New York lost twenty-seven killed and seventy-five wounded, with the entire brigade suffering 540 casualties in total. Among these New York casualties were seventy-five men who had responded to Meagher's speech at the Armory three weeks earlier. ${ }^{69}$ One soldier in the Irish Brigade explained that the fighting was so bad because once "The rebels saw the green flag of our Irish Brigade, and knew that Brigade was coming in, [they] immediately formed a whole division in

\footnotetext{
${ }^{64}$ Anthony W. McDermott, A Brief History of the 69th Regiment Pennsylvania Veteran Volunteers, from Its Formation until Final Muster Out of the United States Service (Philadelphia: PA: D. J. Gallagher \& Co., 1889), 21. ${ }^{65}$ William C. White, 69th Pennsylvania Infantry, Camp on Bolivar Heights, September 26, 1862, 69th Pennsylvania Infantry Vertical File, Antietam National Battlefield Collection.

${ }^{66}$ When there was not enough time for a priest to hear confessions, priests could give absolution to give their men courage, so that should their men die in battle, their sins would be forgiven. Although Father William Corby's general absolution at Gettysburg is the most famous, Father Gillen's absolution at Manassas was probably the first time absolution was given during the Civil War.

${ }^{67}$ Corby, Memoirs of Chaplain Life, 112.

${ }^{68}$ Bradley M. Gottfried, The Maps of Antietam: An Atlas of the Antietam (Sharpsburg) Campaign, Including the Battle of South Mountain, September 2-20, 1862 (El Dorado Hills, CA: Savas Beatie LLC, 2012), 200; see also Stephen W. Sears, Landscape Turned Red: The Battle of Antietam (New Haven, CT: Ticknor \& Fields, 1983), 242245.

${ }^{69}$ Bilby, Remember Fontenoy!, 60; Francis Amasa Walker, History of the Second Army Corps in the Army of the Potomac (New York: C. Scribner's Sons, 1886), 123, 60.
} 
our front." "It was probably the most severe battle ever fought in the country," he wrote, remembering that, "Our poor fellows fell like grass all along the lines.",70

The losses at Antietam reflected the tenacity and valor of Irish-American soldiers but the casualty reports shocked and devastated families at home. Even though their identity as soldiers loomed largest during the bloody fight, in the weeks following the battle, ethnic identity became more important for Irish Americans as they reflected on their loved ones who were lost. The New York Irish American recorded the Irish killed and wounded, stating that the Irish, "we are sorry to say, has suffered severely in that most desperate of all the struggles in which the Union troops have been engaged." ${ }^{, 71}$ Even with their great effort put forth, claims made by native-born Americans tried to diminish the valor of the Irish Brigade at Antietam. Meagher's bravery was put into question by Union colonel David Hunter Strother who wrote in his journal claiming, "Meagher was not killed as reported, but drunk, and fell from his horse."72 Two weeks after the battle, a correspondent for the Cincinnati Gazette made a similar remark, stating Meagher "was not in the charge at all! — did not lead or follow it! He was too drunk to keep the saddle, fell from his horse...several times [and] was too stupidly drunk to answer the simplest question."73 Claims like these circulated throughout northern papers and created added uneasiness among Irish communities in New York and elsewhere.

The large loss of Irish life at Antietam and the nativist attacks against Meagher, which claimed he was intoxicated during the battle, once again united Irish Americans behind their ethnic identity. Following the reports of drunkenness that were spread in northern newspapers,

\footnotetext{
${ }^{70}$ Henry H. Robbins, 29th Massachusetts Infantry, Sharpsburg, Maryland, September 21, 1862, 29th Massachusetts Infantry Vertical File, Antietam National Battlefield.

${ }^{71}$ Irish American, September 27, 1862.

${ }^{72}$ Sears, Landscape Turned Red, 243-244.

${ }^{73}$ Quoted in J. Cutler Andrews, The North Reports the Civil War (Pittsburgh: University of Pittsburgh Press, 1955), 284.
} 
the Irish American reported that "A miserable scribbler who writes from Washington to the Cincinnati Gazette, has taken advantage of the privilege of publishing extended to him, and the security of his anonymous position, to indite a most scurrilous attack upon General Meagher." They continued, defending their Irish general by denouncing the claim saying it was "so outrageous a falsehood that it at once stamps the character of the writer; as General Meagher's presence and gallantry on the field are too well known to the army to admit of doubt." $" 74$ Even soldiers of the Irish Brigade who admitted that Meagher "had one besetting sin....the besetting sin of so many Irishmen" argued that he was always "first to lead the way" into battle. ${ }^{75}$ Few native-born readers wanted to acknowledge the fact that non-Irish soldiers also enjoyed alcoholic beverages. For Irish Americans, this was yet another example they could point to in showing that native-born Americans had no respect for the sacrifices they were making for Unionism. Therefore, this perception angered Irish Americans in the weeks following and caused them to feel attacked because of their Irish identity.

Possibly more persistent than the idea of the hard-fighting Irish is that of "the drunken Irishman," which plagued the ethnic group throughout the nineteenth century. The rumors of Meagher's intoxicated state at Antietam helped spread the idea of Irish drunkenness. Conventional wisdom of the time, particularly due to the evangelical message of the Second Great Awakening, saw drunkenness as a sin. French immigrant and Union general, Régis de Trobriand recalled, "the Irish have two prevailing faults, uncleanliness and a tendency to drunkenness" and when "whiskey was introduced into the camp clandestinely, it was in the Irish quarter that the officer of the guard first found it." ${ }^{, 76}$ Similarly, the heavy drinking that accompanied St. Patrick's Day celebrations in the Army of the Potomac also cast a negative

\footnotetext{
${ }^{74}$ Irish American, October 11, 1862.

${ }^{75}$ McCarter, My Life in the Irish Brigade, 16-17.

${ }^{76}$ Régis de Trobriand, Four Years with the Army of the Potomac (Boston: Tichnor and Company, 1899$) 81$.
} 
image on the Irish. Not only did onlookers ignore the religious importance of the holiday, but the drinking bouts were often exaggerated. One soldier who witnessed the St. Patrick's Day festivities recalled in a letter to his niece that "Whiskey was very plenty and 'Ye brave sons of Erin' availed themselves of its invigorating properties to a large extent." ${ }^{, 77}$ Although those in the Irish communities defended the attacks against Meagher, soldiers were not afraid to admit that he was "a whole-souled and perfect gentleman, this weakness excepted."

Irish accounts and actions during the Civil War show that some men of the ethnic group were aware of their supposed weakness to alcohol and even made attempts to address it. Life in the army made it more difficult for the Irish and native-born Americans to get alcohol. A soldier in the Irish Brigade wrote home to his wife insisting "you need not be afraid of my drinking now for there is no licker alowed in the army" and that " $\mathrm{i}$ had not taste any licquer since $\mathrm{i}$ joined the regiment untill last sunday." ${ }^{, 79}$ One Irishman explained that "a drunken Private soldier" is "seldom seen" because alcohol sells for "three dollars a pint and not enough in the market to supply the Officers.... So the Private soldier would have to get quite an increase in pay before he could get enough in one payday to get on a good drunk. ${ }^{" 80}$ Even when alcohol was present in the camps, men sometimes chose to abstain from the intoxicating beverage. Private William McCarter of the 116th Pennsylvania Infantry wrote home saying, "Strange as it may appear, at least half of the cider was still in the bucket next morning, although none of our party were temperance men. We preferred our favorite army beverage, strong, hot coffee." ${ }^{\prime 1}$ When McCarter wrote "temperance men" he may have been referring to the Irish Brigade Temperance

\footnotetext{
77 Will, 27th Connecticut Infantry, Camp near Falmouth, Virginia, March 18, 1863, Bound Volume 119-05, Fredericksburg and Spotsylvania National Military Park Collections.

${ }^{78}$ Welsh, Irish Green and Union Blue, 70.

${ }^{79}$ Welsh, Irish Green and Union Blue, 17, 42.

${ }^{80}$ Gancas, Dear Teres, 294.

${ }^{81}$ McCarter, My Life in the Irish Brigade, 119.
} 
Association, which was founded in 1861 by Father James Dillon, chaplain of the 63rd New York Infantry.

Alcohol caused many problems in the army and many Irish Americans acknowledged their addiction to the drink, so men like Father Dillon attempted to make a change. The young priest believed alcohol "was the father of all crimes, especially among those with Irish blood in their veins" and had a medal struck for members of the group (Figure 4). In a speech to the 63rd New York, Dillon reminded the audience of the Irish's long struggle with the beverage when he stated, "Show me an Irish Catholic who is not addicted to the vice of drunkenness, and I will find a good citizen of the Republic.... I have in my mind one conspicuous example in the hopeless struggle of Ireland, in '98, where the insurgents met disaster after routing the enemy, because they gave way to festivity when they should have taken advantage of their dearly bought success." After Dillon concluded his speech, he requested that those not willing to join the temperance association fall back, but remarkably, not one of the 700 men did so. After all the names were taken, the men pledged: "I promise, with Divine Assistance, to abstain from all intoxicating liquors, and to prevent as much as possible, by word and example intemperance to others." Although it is unclear how many more men joined or if the 700 men upheld their pledge, during the Peninsula Campaign of 1862, whiskey rations were issued to mix with quinine to prevent malaria but "the men who wore the temperance medals... absolutely refused to touch the stuff." 82

The problem with alcohol abuse extended far beyond the Irish regiments and was troublesome throughout the army. In February 1862, while reviewing a case of insubordination in Joseph Hooker's Division, General McClellan expressed his frustration towards alcohol when

\footnotetext{
${ }^{82}$ Dillon's mention of '98 is a reference to the Irish Rebellion of 1798. Here, the Irish revolted against the British who dominated the Kingdom of Ireland at the time. Corby, Memoirs of Chaplain Life, 291-294.
} 
he stated, "No one evil agent so much obstructs this army... as the degrading vice of drunkenness. It is the cause of by far the greater part of the disorders which are examined by court-martials. It is impossible to estimate the benefits that would accrue to the service of the adoption of a resolution on the part of officers to set their men an example of total abstinence from intoxicating liquors. ${ }^{183}$ While alcohol negatively affected all types of people in the army, previous historians have bought into the idea of the drunken Irishman and made overgeneralizations about all in the ethnic group. Ella Lonn wrote that of all Irish, "intemperance was one of their vices, and when they were intoxicated, there was constant brawling and fighting among themselves and with other groups; indeed so contentious were they that inebriation was not necessary to start a fight." 84 William Burton similarly wrote that, "Irish regiments did have a serious alcohol abuse problem. While this was chronic in Civil War units of all kinds, it was a particularly acute problem for the Irish regiments. ${ }^{~} 85$ While there is little proof that this is true, this shows the contest between ethnic identity and what made someone Irish in the nineteenth century. Although few Irish Americans linked drunkenness to their ethnic identity, native-born Americans placed particular importance to ascribe this attribute to Irish men and women.

Even though alcoholism continued to plague Irish Americans, the temperance movement apparently had a positive effect on the Irish Brigade. In his postwar memoir, Father William Corby claimed that a noticeable decline in wayward activities in camp occurred after temperance was pledged and an added attendance of Daily and Sunday Mass was reported. ${ }^{86}$ Although this is possible, very few accounts written during the war talk about the Irish Brigade Temperance

\footnotetext{
${ }^{83}$ Bell Irvin Wiley, The Life of Billy Yank: The Common Solider of the Union (Indianapolis, IN: Bobbs-Merrill, 1952), 252.

${ }^{84}$ Ella Lonn, Foreigners in the Union Army and Navy (Baton Rouge: Louisiana State University Press, 1951), 648. ${ }^{85}$ William L. Burton, Melting Pot Soldiers: The Union's Ethnic Regiments (New York: Fordham University Press, 1998), 153.

${ }^{86}$ Corby, Memoirs of Chaplain Life, 293-294.
} 
Association. This suggests that the temperance society was not as important in the lives of soldiers of the brigade, yet it factored heavily in the minds of its military and religious leaders. Furthermore, the Irish Brigade's Temperance Association was featured more often in the postwar accounts, which suggests that it may have been used as an attempt to challenge the preconceived notions of Irish drunkenness.

Irish losses at Antietam and the accusations of Meagher's drunkenness were combined with a series of controversial political and military decisions made by President Lincoln, which angered Irish-American communities and affected their overall willingness to support the Union. In the days following the Union victory at Antietam, Lincoln issued his preliminary Emancipation Proclamation, which would go into effect on the first of January and free all enslaved people held in Confederate territory. The new law would not free those held in bondage in slaveholding states loyal to the Union or slaves in formerly Confederate lands now under the control of Federal forces. However, Lincoln's Emancipation Proclamation changed the war from one fought to preserve the Union into a war to end the institution of slavery. While unpopular to many Northerners, Irish Americans were particularly disturbed by the changing war aims.

Attacks against the Emancipation Proclamation came quick and enraged Democrats who already questioned the Lincoln administration's actions. While the President envisioned unpopular criticism, he knew how crucial enslaved labor was to the Confederacy, so he classified his proclamation as a military necessity, thus defending the constitutionality of his action. William McIntyre, an Irishman in the 95th Pennsylvania Infantry, made it clear how he felt in a letter he wrote to his family back home. He wrote, "I think the Radicals of the Northeast want this Govt broken up and they think by so doing they will get the Middle States with them but they are mistaken Pennsylvania, New York, and New Jersey will never take up with such a set of 
hypocrites and defamers of a country’s Rights as the Abolition Party are." ${ }^{17}$ Similarly, an Irish American in the 78th Pennsylvania Infantry showed his consciousness with the Democratic Party when he stated that, "we came out to fight for the Union not for the Negro" and explained how "many of our men has deserted" because of the Emancipation Proclamation. ${ }^{88}$ One Irishman mirrored the feeling of the paper and expressed Irish dissatisfaction with the Emancipation Proclamation when he wrote, "The feeling against nigars is intensly strong in this army as is plainly to be seen wherever and whenever they meet them. They are looked upon as the principal cause of this war and this feeling is especialy strong in the Irish regiments." ${ }^{89}$

Many Irish Americans saw the Emancipation Proclamation as a clear example of Republican support for abolitionists, and therefore a direct attack against the Democratic Party. For Democrats, particularly for the Irish in cities like New York, the end of slavery meant millions of African Americans rushing north to compete in the already difficult labor market. It also meant that the only class thought to be below the Irish would now be considered equal to the ethnic group. This was expressed in a letter written by an Irishman, who wrote home to his mother saying "there is great dissatfaction among the troops here for the half of them wont fight to free negroes nor fight with them if ever the[y] put a negro in the field with our armey every Black son of a Bich of them will get killed as soon as the[y] come." ${ }^{\text {90 }}$ Private James Welsh wrote home, telling his family that he hoped a friend "will not be so foolish as to mary a Abe Lincoln Abolisionist for I think it is the ruin of the country." ${ }^{, 1}$ While ethnicity remained an important

\footnotetext{
${ }^{87}$ Civil War Widows' Pension of William McIntyre, 95th Pennsylvania Infantry, accessed at fold3.com, February 6, 2019.

${ }^{88}$ Gancas, Dear Teres, 194.

${ }^{89}$ Corby, Memoirs of Chaplain Life, 62.

${ }^{90}$ Civil War Widows' Pension of Dan Dillon, 10th Illinois Cavalry, accessed at fold3.com, February 6, 2019.

${ }^{91}$ Civil War Widows' Pension of James Welsh, 82nd Pennsylvania Infantry, accessed at fold3.com, February 6, 2019.
} 
factor during this time, their identity as Democrats became vitally important to the IrishAmerican community.

New York's gubernatorial candidate Horatio Seymour shared similar views with Irish Americans and hoped Democrats would gain a majority over the Republicans before Lincoln's Emancipation Proclamation went into effect on January 1. In New York, Democrats announced that, "a vote for Seymour is a vote to protect our white laborers against the association and competition of Southern negroes." 92 The Irish American argued that if Seymour was not elected, treason and corruption would continue. While this Irish paper appealed to the ethnic identity of Irish Americans, it also understood that many of its readers identified as Democrats. The paper warned that if,

you elect the Abolition candidate, Wadsworth, you do away with the good effects of the patriotic action of those States, and give renewed vitality to the foul conspiracy against the Republic; you endorse the violation of the Constitution, of which the Abolition faction have been guilty, and place the Federal government entirely at the mercy of an unscrupulous cabal, of whose wanton abuse of power you have had, unfortunately, too sad an experience.

However, a vote for Seymour meant that you would "strengthen the legitimate powers of the government, and ensure to it the unwavering support of the Empire State in every constitutional effort for the restoration of the Union to its pristine integrity and glory. ${ }^{93}$

Two days after signing the preliminary Emancipation Proclamation, Lincoln caused further disillusionment for Irish Americans with the suspension of habeas corpus. The president authorized military trials for "all persons discouraging volunteer enlistments, resisting militia drafts, or guilty of any disloyal practice." 94 This resulted in the imprisonment, without trial, of hundreds of draft protestors, five newspaper editors, three judges, and numerous political

\footnotetext{
${ }^{92}$ New York World, October 18, 1862.

${ }^{93}$ Irish American, October 25, 1862.

${ }^{94}$ Abraham Lincoln, The Collected Works of Abraham Lincoln, ed. Roy P. Basler, (9 vols.: New Brunswick, NJ: Rutgers U.P., 1953-1955), 5:436-437.
} 
leaders. ${ }^{95}$ For Irish Americans, this was reminiscent of the Penal Codes of Ireland and therefore, caused them to equate the Republican Party to the British government. While most Irish Americans sided with the Democrats before this point, many more began to view the Republicans as a tyrannical party that needed to be stopped. This was reminiscent in the army as well, with one soldier in the 1st New York Heavy Artillery explaining that, if "they wasent democrats when they enlisted...they have changed since Republicanism is played out in the army." ${ }^{96}$ Irish American and Northern distaste towards the Emancipation Proclamation and the suspension of habeas corpus was shown through the results of the 1862 congressional elections. Democrats gained thirty-two seats in the House and won the governorships of New York and New Jersey. They also gained control of the legislatures in New Jersey, Indiana, and Illinois. ${ }^{97}$ After the election results, the Irish American reported, "The triumph of right, embodied in the persons of the Democratic candidates, was never clearer or more decided. ${ }^{98}$ For Irish Americans in New York, this was not only a victory for the Democrats and their communities, but it was also an early example of how they as an ethnic group could use their unity to enact change.

President Lincoln further alienated Irish Americans with his decision to remove General George B. McClellan from command of the Army of the Potomac on November 7, 1862 and replace him with a reluctant Ambrose E. Burnside. McClellan displayed a constant case of what Lincoln called "the slows," and his inability to follow up after the Union victory at Antietam was the last straw for the president. ${ }^{99}$ This decision was almost as controversial as the Emancipation Proclamation due to the fact that the men of the Army of the Potomac adored McClellan as a

\footnotetext{
${ }^{95}$ James M. McPherson, Battle Cry of Freedom: The Civil War Era (New York: Oxford University Press, 1988), 493.

${ }^{96}$ Private James E. Decker, 1st New York Heavy Artillery, Falmouth, Virginia, Letter to Father, November 30, 1862, Bound Volume 418-01, Fredericksburg and Spotsylvania National Military Park Collections.

${ }^{97}$ James M. McPherson, Ordeal by Fire: The Civil War and Reconstruction, 3rd ed. (New York: McGraw-Hill, 2001), 319-320.

${ }^{98}$ Irish American, November 15, 1862.

${ }^{99}$ McPherson, Ordeal by Fire, 323-324.
} 
commander. Many soldiers felt that the General was concerned about their well being, while politicians were more worried about fighting battles. The removal of McClellan was particularly unpopular among Irish soldiers and added to the disillusionment of the Irish Brigade and their ethnic community. "The feeling was so intensely bitter at this change that several officers [of the Irish Brigade] tendered their resignations. 'Little Mac' was a great favourite with the army — his very name was a talisman" wrote Captain David Power Conyngham. ${ }^{100}$ During McClellan's farewell parade, which resembled 'the 'Dead March' at a soldier's funeral," Meagher ordered the Irish Brigade to lay down their green Irish flags as a show of respect for their favorite commander. McClellan was honored by the act but insisted the men retrieve their colors and follow their new commander, Burnside. ${ }^{101}$ These decisions made by Lincoln in the fall of 1862 created an undercurrent of despair, which was strong among Irish communities and would only be heightened with the debacle at Fredericksburg.

While many considered Antietam a great Union victory at first, as time went on and the casualty reports were circulated throughout the northern papers, the Lincoln administration realized it was not a miraculous success. This realization came after the preliminary Emancipation Proclamation was issued, which meant the President needed a military victory to silence his opponents before it went into effect on January 1, 1863. Without a Union victory before the start of the new year, the already demoralized soldiers and civilians of the North would have little support for the continuation of a war now centered on the abolition of slavery. Lincoln's need for a victory meant that the newly appointed general, Ambrose Burnside was forced to fight a winter campaign, something almost unheard of in the nineteenth century. The Army of the Potomac was an army in turmoil when he took command and his troops doubted his

\footnotetext{
${ }^{100}$ Conyngham, The Irish Brigade and its Campaigns, 158.

${ }^{101}$ McCarter, My Life in the Irish Brigade, 68.
} 
ability to follow in the footsteps of their beloved commander, McClellan. However, Burnside moved quickly, marching his Army southward towards Richmond. To get to the Confederate capital, he needed to take his army across the Rappahannock River and through the city of Fredericksburg. Unfortunately for the newly appointed general, his army was delayed by the late arrival of pontoon boats, which forced him to fight the rebels who had weeks to prepare for the December battle. ${ }^{102}$

As with other battles fought in 1862, the Irish Brigade again showed their tenacity and bravery at Fredericksburg. On the morning of December 13, the brigade fell in along the banks of the Rappahannock River and waited their turn to advance against the Confederate defenses positioned atop Marye's Heights, about a half-mile outside the colonial town. Here, men under Major General James Longstreet's I Corps were in a superb defensive position in a sunken road bordered by a stonewall. The Confederates were dug in here, with rows of rifle pits behind them and artillery support from Colonel Edward Porter Alexander prepared to cause havoc for the charging Union soldiers. One soldier of the Irish Brigade was obviously worried as he confided to his chaplain saying, "Father, they are going to lead us over in front of those guns which we have seen placing, unhindered, for the past three weeks."103

Although many Irish Americans were starting to doubt their place in the Civil War, some native-born citizens recognized their sacrifice. Prior to Fredericksburg, the green flags of Erin, which were normally carried by the regiments of the Irish Brigade, were sent home to New York for repair. On December 2, a ceremony was held in which native-born Americans in New York presented new regimental colors, "in grateful commemoration of the gallant deeds" who had won "the unqualified praise of all," to the Irish Brigade. New Yorker, Henry F. Spaulding explained,

\footnotetext{
${ }^{102}$ Francis Augustín O’Reilly, The Fredericksburg Campaign: Winter War on the Rappahannock (Baton Rouge: Louisiana State University Press, 2003), 4-6.

${ }^{103}$ O'Reilly, The Fredericksburg Campaign, 121.
} 
the Irishmen would be pleased if they could "see with enthusiasm their services are appreciated. On the soil of their adoption they have added fresh and enduring pages to the chivalric history of their native land." ${ }^{104}$ This left the men of the Irish Brigade in need of a surrogate for their missing green banners, as only the newly added 28th Massachusetts Infantry had their regimental flag during the time of the battle. To remedy the situation, Meagher ordered all of his soldiers to place sprigs of green boxwood into their kepis so both Union and Confederate soldiers would recognize the men of his brigade. ${ }^{105}$

Around one o'clock, the Irish Brigade began their assault on Marye's Heights. As they passed the dead and wounded Union soldiers from the previous assaults, their identity as United States soldiers took prominence. The Irishmen managed to maintain their formation as they confronted a storm of bullets, grapeshot, and canister, which inflicted horrifying casualties. Private William McClelland of the 88th New York wrote that "Up hill and forward over an open plain a quarter of a mile wide we rushed, the enemy firing with their rifles deadly volleys...[when] we were within thirty or forty yards of the rifle pits, we met dreadful showers of bullets from three lines of enemy, besides their enfilading fire. Our men were mowed down like grass before the scythe of the reaper." 106 "This useless sacrifice of life was kept up all day on the 13th, and well into the night," recalled John Dwyer of the 63rd New York Infantry. 107 "No pen can describe the horrors of this battle," remembered George Nugent of the 69th New York Infantry. Recalling "the casualties were enormous. It was a living hell from which escape seemed

\footnotetext{
${ }^{104}$ Conyngham, The Irish Brigade and its Campaigns, 161-164.

105 Doyle, A Party of Mad Fellows, 215-216.

${ }^{106}$ Irish American, January 10, 1863.

${ }^{107}$ Major John Dwyer, 63rd New York Infantry, Address of John Dwyer at the 52nd Anniversary of the Battle of Fredericksburg held at the Union Square Hotel in New York City, December 12, 1914, Bound Volume 038-08, Fredericksburg and Spotsylvania National Military Park Collections.
} 
scarcely possible." 108 Of the thirteen Union assaults against the heights that day, the Irish Brigade is recognized for pushing the furthest. Although they reached within yards of the stonewall, the men failed to take the position and by the end of the afternoon, the shattered Brigade and the rest of the Union Army was left on the field of battle. ${ }^{109}$ An Irish Brigade captain declared, "Oh! It was a terrible day. The destruction of life has been fearful, and nothing gained." 110

The Union army suffered tremendously, as nearly 13,000 men becoming casualties, with the Irish Brigade bearing a heavy portion of the loss. Of those in the Irish Brigade who entered the battle of Fredericksburg, the 69th New York lost 16 of its 18 officers and 112 of the 210 men were killed, wounded, and missing. ${ }^{111}$ The 88th New York suffered a fifty percent casualty rate while the 63rd New York lost forty-four of its 162 men that went into battle. The 116th Pennsylvania lost most of its officers and men, while the 28th Massachusetts Infantry, which had just joined the brigade in the fall, lost 158 men on the field of battle. ${ }^{112}$ Father William Corby, chaplain of the 88th New York, was horrified when he witnessed the suffering of his Irishmen, declaring, "the place into which Meagher's brigade was sent was simply a slaughter-pen.""113 Captain David Conyngham described the action at Fredericksburg as "a wholesome slaughter of

\footnotetext{
${ }^{108}$ Third Annual Report of the State Historian of the State of New York, 1897 (New York: Wynkoop Hallenbeck Crawford Company, 1898), 42.

${ }^{109}$ The Irish Brigade's attack at Fredericksburg has become known as the most famous clash between Irishmen because some claim that the 24th Georgia, which opposed the Irish Brigade at the stone wall, was an Irish regiment. This has become widely popular, especially after the Georgia regiment was portrayed as Irishmen in the movie Gods and Generals. This is not true however. Neither the 24th Georgia nor Irish-commanded McMillan Guards (Company E) were made up of Irishmen. Colonel Robert Emmet McMillan, was an Irish immigrant from Ulster, and was one of the six Irishmen in company, with the rest being American-born. The Lochrane Guards, an Irish company in the Phillips Legion, was stationed to the left of the 24th Georgia and did fire upon the Irish Brigade at Fredericksburg but by this time, the company had been reduced to about forty-seven men, with none of these soldiers leaving accounts of their experiences. See, David T. Gleeson, The Green and the Grey: The Irish in the Confederate States of America (Chapel Hill, NC: The University of North Carolina Press, 2013), 105.

${ }^{110}$ Irish American, December 27, 1862.

${ }^{111}$ William F. Fox, Regimental Losses in the American Civil War (Albany, NY: Albany Publishing, 1889), 204.

${ }^{112}$ Francis Amasa Walker, History of the Second Army Corps in the Army of the Potomac (New York: C. Scribner's Sons, 1886), 192.

${ }^{113}$ Corby, Memoirs of Chaplain Life, 132.
} 
human beings - sacrificed to the blind ambition and incapacity of some parties" rather than a battle. ${ }^{114}$ A soldier of the 88th New York Infantry, expressed the somber situation the best when he wrote, "The battle of Fredericksburg should be written in letters of blood on the banners of the Irish Brigade." 115

As the most visible example of Irish arms in the Union service, the Irish Brigade's suffering at Fredericksburg played an influential role on ethnic morale and left Irish neighborhoods in the New York infuriated. On December 27, 1862, the New York Irish American published a letter written by Captain William J. Nagle of the 88th New York to his father the day after the battle. "Irish blood and Irish bones cover that terrible field to-day," Nagle wrote, saying, "we are slaughtered like sheep, and no result but defeat." 116 One Irishman simply stated, "As for the remnant of the Brigade, they were the most dejected set of Irishmen you ever saw or heard of." ${ }^{117}$ When General Meagher returned to New York in January for a high mass recognizing the sacrifices of the Irish Brigade, he found Irish disillusionment on the home front as well. Irish communities in New York read the newspapers and saw the lengthy casualty reports, which came only a few months after those from Antietam. Irish Americans at home mourned the loss of their husbands, fathers, and sons, and challenged the idea of sending more Irishmen into the ranks of the Union army. The Irish American warned General Meagher that recruitment of Irishmen would only work "if men can yet be found to volunteer in a war-[if] the conduct of which reflects anything but credit on those who have undertaken its management." 118

\footnotetext{
${ }^{114}$ Conyngham, The Irish Brigade and its Campaigns, 343.

${ }^{115}$ Irish American, January 10, 1863.

${ }^{116}$ Irish American, December 27, 1862.

${ }^{117}$ Conyngham, The Irish Brigade and its Campaigns, 350.

${ }^{118}$ Irish American, December 27, 1862.
} 
The disenchantment among Irish Americans in New York only grew stronger into one unified voice as the sacrifice and cost of the Irish Brigade seemed to go unnoticed and unappreciated by native-born Americans. In a letter published on January 17, 1863, by the Irish American, Colonel James Meehan of Corcoran's Irish Legion angrily pointed out that they could not get an account of the Irish Brigade's actions at Fredericksburg in any of the New York newspapers. Hinting at nativism, the letter stated, "Though we were certain that they fought well and bravely...yet we wished to have the particulars - every other brigade being particularized." ${ }^{119}$ Irish soldiers and civilians called for the removal of the Irish Brigade from the field until they could be recruited up to fighting strength. The Irish Brigade "is so small now that it is not fit to go into any further action unless it is recruited up," wrote an Irish soldier. ${ }^{120}$ With a similar belief, the most popular Irish newspaper in New York warned the War Department that, "To bring them into conflict with the enemy in their present condition, is an outrage on humanity of which we trust the government will not be guilty." 121

As anger grew among Irish-American communities at home in New York, Meagher pushed President Lincoln and Secretary of War Edwin M. Stanton to grant special leave time for the Irish Brigade to rest and recruit its depleted ranks. Sometimes, Meagher's requests went without response and at other times War Department officials explained that there were not enough troops in the field to grant the brigade's leave request. ${ }^{122}$ One soldier in the Irish Brigade wrote home to his mother, pointing to nativism as the cause for the men not receiving permission to be sent home. "We thought surely that our brigade was going home to New York" he said,

\footnotetext{
${ }^{119}$ Irish American, January 17, 1863.

${ }^{120}$ Welsh, Irish Green and Union Blue, 40.

${ }^{121}$ Irish American, January 17, 1863.

122 Bruce, The Harp and the Eagle, 153-155.
} 
"but we were kept back and would not be let go in account of we being Irish." 123 As this news spread, Irish men and women in New York erupted with anger and accused the government of outright prejudice. An editor of the Irish American angrily reported, "it appears to me as if they were most anxious to blot out our race altogether....they seem not to recollect the fact that they are doing all in their power to demoralize the remnant of a magnificent brigade." ${ }^{24}$ When the War Department argued that the Union was in too precarious a position to grant whole brigades leaves of absence, Irish Americans pointed to units from other states that secured periods of rest. Capturing the mood, the Irish American argued, "If the Brigade were not so markedly and distinctively Irish, they would not have been treated with the positive injustice to which they have been exposed." 125 Boston's Irish newspaper the Pilot went even further by describing the feeling among Irish Americans when it cried, "the Irish spirit for the war is dead! Absolutely dead!"126

While Irish-American communities dealt with the loss of family and friends, they were also faced with the passage of the Emancipation Proclamation and the creation of African American regiments. On New Year's Day, President Lincoln signed the Emancipation Proclamation, which was not only justified as a military necessity but also sanctioned the enlistment of black soldiers into Union forces. This was not popular among the Northern population, and it was especially unwelcome by Irish Americans. "I am sory to say that we are compeled to fight for the damed black nigger, but such is the case now and we can't help it now," wrote one Pennsylvania Irishman. ${ }^{127}$ Another soldier from New York expressed the

\footnotetext{
${ }^{123}$ Civil War Widows' Pension of William Dwyer, 63rd New York Infantry, accessed at fold3.com, August 14, 2019.

${ }^{124}$ Irish American, January 17, 1863.

125 Irish American, March 14, 1863.

${ }^{126}$ Boston Pilot, May 30, 1863.

${ }^{127}$ Gancas, Dear Teres, 205.
} 
feeling of many when he explained, "if they are going to arm the niggers they had better send them south [because] they can stand the heat \& I guess that is about all.” He continued, stating "there is a great deal of talk in camp about Old abes emancipation and arming the blacks[.] The soldiers say they wont fight by the side of a nigger." ${ }^{128}$ Many Irish Americans felt that the newly created black regiments, and African Americans in general, were given priority over white soldiers. A soldier in the Irish Brigade was angered over this thought and exclaimed, " $\mathrm{i}$ donte think mutch of that for I would shoote one as quick as [a] wink if the[y] gave one any says..."129 This realization, along with the thousands of soldiers lost during 1862, left Irish American communities questioning their place in the Civil War.

The year 1862 began with the formation of the Irish Brigade but ended with Irishmen reexamining their place in the Union war effort. With the horrendous loss of Irish life at Antietam and Fredericksburg, the removal of their beloved general George B. McClellan, and Lincoln's controversial Emancipation Proclamation and the suspension of habeas corpus, Irish Americans who initially supported the war began to feel as though the Union was no longer worth preserving. Irish nationalists who were fighting to gain military experience for their future war against England were left to bury the dead, and realized there were few Irishmen left to fight such a battle. Similarly, those on the home front read the growing casualty reports that filled page after page and worriedly looked for the names of their loved ones.

For increasing numbers of Irish Americans in New York and elsewhere, the cost of war and its changing goals no longer seemed worth the sacrifice. These individuals began to place their ethnic identity above their devotion to America. While some saw the war solely through

\footnotetext{
${ }^{128}$ Private James E. Decker, 1st New York Heavy Artillery, Falmouth, Virginia, letter to sister, February 13, 1863, Bound Volume 418-01, Fredericksburg and Spotsylvania National Military Park Collections.

${ }^{129}$ Private William Smith, 116th Pennsylvania Infantry, Camp Near Falmouth, Virginia, Letter to Sister, February 11, 1863, Bound Volume 151-14. Fredericksburg and Spotsylvania National Military Park Collections.
} 
their American patriotism, others who were recent immigrants, saw the need to view the conflict in terms of how it would benefit them as Irish men and women. As this reversal in IrishAmerican support occurred, native-born citizens became increasingly agitated with the ethnic group. As the next chapter will demonstrate, a growing divide between the native-born and the Irish-American population occurred. Native-born Americans would point to the 1863 violence that erupted, and the large Irish population that participated in these events. Amid this disillusionment and nativism, Irish Americans in New York began to further embrace their ethnic heritage and unite behind it.

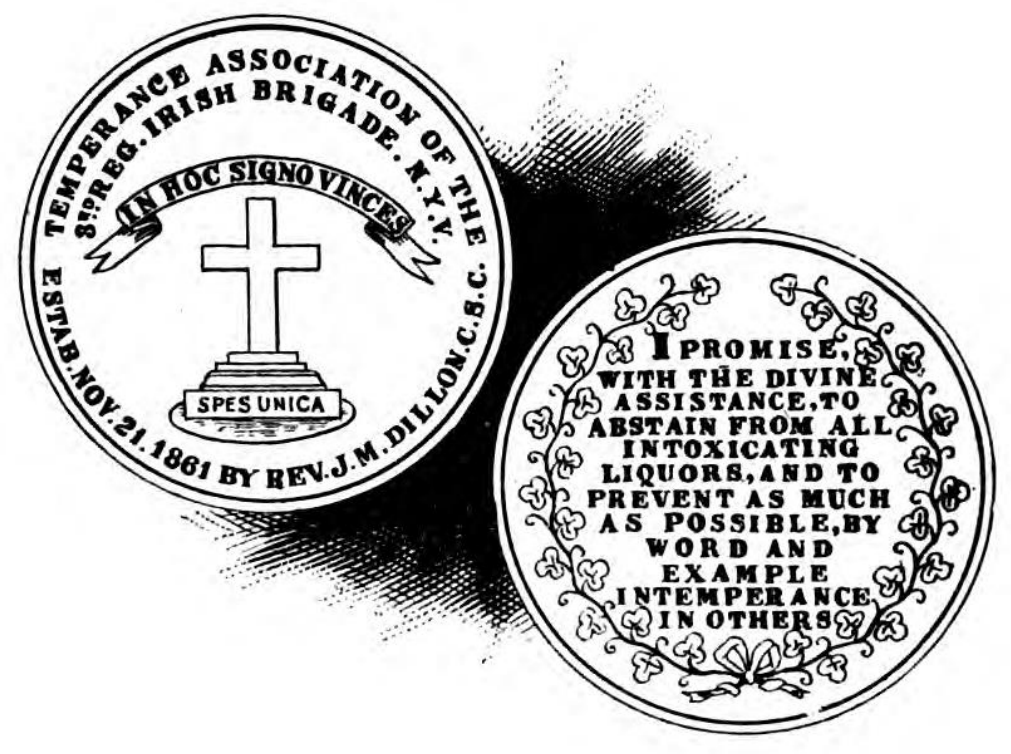

TEMPERANCE MEDAL.

Figure 4: Rendition of the Irish Brigade's Temperance Medal Struck by Chaplain James M. Dillon. 


\section{Chapter III}

"The Irish spirit for the war is dead:" Tension on the Home Front, The Collapse of Irish Support, and its Impact on their Treatment in America

The changing war aims of 1862, along with the large loss of life, left Irish Americans in New York entering the new year frustrated. Although the debacle at Fredericksburg caused the morale of all Americans to decrease, Irish Americans on the front and at home began to feel like the war no longer supported their interests. This change in support for the Union had a negative impact for the Irish-American community in New York. As outrage among the ethnic group reached new heights, a growing divide began to emerge. Irish disillusionment continued to grow throughout 1863 due to the federal and state drafts. This frustration culminated in the New York City draft riots and cast a dark shadow on the Irish population of the city for years to come. While some Irish Americans supported the actions of their ethnic community, native-born Americans felt betrayed by the group. Nativist prejudice reemerged and intensified during this time as well. Even as some New York Irish continued to support the Union for the rest of the war, many also chose to demonstrate their ethnic identity through Irish festivities and relief organizations. These endeavors created a more tightknit group of individuals who were bound together by their diasporic ethnic background. As the Irish in New York and elsewhere continued to face nativist attacks, they nonetheless turned to their ethnic ties to get ahead and become a powerful voice in the postwar era.

1863 began in sorrow for many Irish Americans at home in the Northeast, as friends and families mourned the loss of loved ones of the Irish Brigade. On the morning of January 16, St. Patrick's Cathedral in New York City hosted a Grand Requiem Mass for the dead men of the Irish Brigade. The cathedral filled quickly. Attendants included everyone from well-known 
individuals such as Thomas Francis Meagher and his wife, to widows of the poorest private soldier in the unit. At the ceremony, former chaplain of the 69th New York State Militia Father O'Reilly reiterated the fact that the men of the Irish Brigade were fighting for not only the Union, but also Ireland and the Catholic Church. In his speech, he reminded the audience that the soldiers, "bravery and fidelity to their flag, was bravery and fidelity to God." Irish nationalist and writer John Savage also spoke of the sacrifice of the Irish Brigade and what it meant for the community rather than the nation when he said, "Proud beats the heart while it sorrowing melts / O'er the death-won fame of these truthful Celts. / For the scattered graves over which we pray / Will shine like stars on their race away."1 As seen with the ceremony, diasporic ties became increasingly more important to the ethnic group in New York as the war progressed.

The mood of soldiers in the Irish Brigade was similarly depressed, and the military actions only added to the disillusionment and antipathy. After the defeat at Fredericksburg, Irish and native-born soldiers alike were left in low spirits. In an attempt to renew the offensive against the Confederates, Union General Ambrose Burnside's plan ended in another horrible debacle. Due to horrendous weather conditions, the maneuver quickly became known as the "Mud March." In a letter home to his family, one Irish American wrote of the depressing incident he and his fellow Union soldiers faced. He stated, "On Tuesday the 20th we started and at night the rain came down in torrents. The next morning we were on the march before daylight and were soaked through to the skin which made us feel anything but in the best of spirits. We marched three miles and as it was impossible to move, the artillery were stuck fast in the mud." He continued, writing, "We laid for two days in the mud like a parcel of hogs and on the fifth day Burnside made up his mind to turn our Brigade into jack-asses or some other kind of an

\footnotetext{
${ }^{1}$ New York Times, January 17, 1863; David Power Conyngham, The Irish Brigade and its Campaigns (Glasgow: R \& T Washbourne, 1866), 174-176.
} 
animal for we were marched two miles stacked arms and started to pull the 'Ponton Boats' out of the mud."2 Like native-born men in the ranks, Irish Americans questioned how these frustrating events affected their life as soldiers rather than as an ethnic group.

Many Irish Americans in the Army of the Potomac pointed to the failure of Fredericksburg and the mud march as cause for their disillusionment and blamed much of it on General Burnside's shortcomings as a qualified commander. As "thousands of wretched stragglers" returned to their camps along the Rappahannock River exhausted and hungry, more and more became disgruntled with the drudgery of army life and the decisions made by the seemingly incompetent commanders. To show their distaste for their general, soldiers constructed an effigy of Burnside and stuck it into the mud. ${ }^{3}$ While ethnic identity often demonstrated the differences among Irish Americans and Anglo Americans, the military actions of the Union Army in Virginia left the two groups united in dissatisfaction.

Irish American soldiers expressed their disillusionment and hatred of war during this time through songs and poems. A soldier in the Irish Brigade eloquently expressed the sorrow that war brought to the country when he wrote:

Among the saddest of all evils sad, / That Heaven's judgment ever sent on earth, / Or hating man inflicts on hated man, / Is War-relentless, ruthless, bloody War

The maddened charge of hostile ranks glowing / With fell revenge, and burning hot with wrath. / My souls is sick of War-its carnage, crime, / Distress and stern, severe necessities. / Oh, war is sad. ${ }^{4}$

\footnotetext{
${ }^{2}$ Civil War Widows' Pension of William McIntyre, 95th Pennsylvania Infantry, accessed at fold3.com, February 6, 2019.

${ }^{3}$ Susannah Ural Bruce, The Harp and the Eagle: Irish-American Volunteers and the Union Army, $1861-1865$ (New York: New York University Press, 2006), 150.

${ }^{4}$ William McCarter, My Life in the Irish Brigade: The Civil War Memoirs of Private William McCarter, 116th

Pennsylvania Infantry, ed. Kevin O’Brien (Cambridge, MA: De Capo Press, 1996), 139.
} 
For this soldier and thousands like him, the start of war was met with excitement and joy, but as time went on and casualties continued to reach unfathomable amounts, soldiers were left feeling "sick of War."

The new year also meant that the Emancipation Proclamation went into effect, leaving some Irish Americans to express their hatred of the Republican Administration and their new war aims in sarcastic song lyrics. An Irishman in the 90th Illinois Infantry was critical of the current administration and how the shift to emancipation negatively affected the lives of soldiers in the field. The sarcastic song titled "One Cracker A Day" had lyrics that included:

To get such cruel treatment indeed it is a shame / But the administration of course is to blame / They've neglected to give us our rations or pay / And compelled us to live on one cracker a day.

We enlisted without a thought that deceived we would be / And sent down to Dixie to set niggers free / We enlisted to fight for a more glorious cause / In defense of our flag, our union, and laws.

Old Abe's proclamation we soldiers do abhor / It will do us no good but will prolong the war / And while this war lasts, it is true what I say / Each soldier must live on a cracker a day.

All the Greeleys and Chanlers will meet their downfall / The abolition bloodhounds contractors and all / For a speech or a vote they get three years pay / Of a soldier who lives on a cracker a day.

Whilst the soldiers are starving the negro grows fat / They get their full rations are clothed and all that / The Abolitionists treat them in a different way / From the soldiers who get but a cracker a day. ${ }^{5}$

These lyrics demonstrate the antagonism held by Irish soldiers who were against abolitionists like President Abraham Lincoln and Horace Greeley. The song was popular enough to be distributed throughout the companies of the 90th Illinois, which showed that multiple servicemen

\footnotetext{
${ }^{5}$ Julia Fulton, “The Civil War Letters of Patrick H. Sloan,” http://juliafulton.com/phsloan/patsloan.htm (accessed February 4, 2019). For the full lyrics, see Appendix A.
} 
held similar opinions. These feelings of antipathy not only reverberated throughout the army, but were also carried throughout the Irish-American communities at home.

Some of the most influential Irish Catholics on the home front reinforced racism among the ethnic group and worked to unify the Irish against African-American achievements and the Republican Administration. Archbishop John Hughes of New York rejected abolitionist beliefs. Catholic historian Jay Dolan has argued that the roots of Irish prejudice against African Americans "in New York and elsewhere can be traced back to the era of John Hughes, when the patterns of discrimination first emerged with a vengeance. ${ }^{96}$ Hughes wrote anonymously in his diocese newspaper, the New York Metropolitan Record, arguing "We Catholics" were fighting for the Union and had no intention "of making this war subservient to the philanthropic nonsense of abolitionism." The article was reprinted in other Catholic newspapers like the Boston Pilot, which identified the archbishop as the author and denied slavery as the cause of the war. The article also stated slavery has existed since "the earliest annals of the human race" and therefore the church had no power to end the institution where it already existed. Hughes also echoed popular beliefs of the time when he claimed that because Africa "is a country of savages," slaves sent to the United States had been saved from the "barbarian spirit of that country." For these beliefs, both African American and white Catholics in New York and elsewhere believed that the Archbishop "does not consider the Black race to be part of his flock" and that he hates the "black race so much that he cannot bear them to come near him." ${ }^{\prime 8}$

Irish-American Judge Charles Patrick Daly, also voiced his frustration and distaste towards the Emancipation Proclamation and the rise of African-American regiments. Daly was

\footnotetext{
${ }^{6}$ Jay P. Dolan, The Immigrant Church: New York's Irish and German Catholics, 1815-1865 (Baltimore: Johns Hopkins University Press, 1975), 25.

${ }^{7}$ Metropolitan Record, October 12, 1861, The newspaper refers to Golgotha, the site where Jesus was crucified; warning that if the abolitionist policy continues the whole country will fall into a scene of death.

${ }^{8}$ Dolan, The Immigrant Church, 24.
} 
an avid supporter of the Irish Brigade and the Irish-American community in New York City. He argued that if African-American regiments were raised, he "would wash his hands of the whole matter.... recruiting was difficult enough now because of the everlasting Negro question..." Daly's wife Maria explained that she and her husband were "heartily sick of the whole business" and complained that "There is no law but the despotic will of poor Abe Lincoln, who is worse than a knave because he is a cover for every knave and fanatic who has the address to use him. Therefore we have not one devil, but many to contend with."9

These opinions on African Americans and the Emancipation Proclamation were mirrored in New York Irish and Catholic newspapers such as the Metropolitan Record and the Irish American. Although these papers do not speak for the entire population, their continuing popularity with New York Irish Catholics indicates the significance of their message. While the Metropolitan Record supported the President at the start of the war, Irish-American editor John Mullaly warned in July 1862, "if this war is to be waged in the interest, and to forward the designs, of abolitionists, he [Lincoln] will find himself sadly mistaken; he will find that white men are not willing to become the tools of sectional agitators, and...if persisted in, can only have one result, the permanent dissolution of the Union..." ${ }^{10}$ When the preliminary proclamation was issued the Metropolitan Record wrote to its readers, that "They [Republican abolitionists] have already cost the country over two hundred thousand lives, and nearly two thousand millions of dollars...[and] we shudder at the terrible consequences which have already resulted from this abolition policy, a policy, which, if persisted in, will convert our happy land into a vast Golgotha." 11 The New York Irish American also wrote negatively about the proclamation and

\footnotetext{
${ }^{9}$ Maria Lydig Daly, Diary of a Union Lady, 1861-1865, ed. Harold Earl Hammond (New York: Funk and Wagnalls Company, Inc., 1962; reprint, Lincoln: University of Nebraska Press, 2000), 177, 179.

${ }^{10}$ Metropolitan Record, July 5, 1862.

${ }^{11}$ Metropolitan Record, October 4, 1862.
} 
what it meant to people in the United States. "By the old and young, Democrat, Republican (except the Abolitionists), Know-Nothing, Free-soiler and Constitutional Union man, all regret that it was ever issued, and say that it was the worst blow yet struck against the Union and Constitution of this once happy and most prosperous land. Since the issue of that unlooked-for document recruiting in this city has almost entirely ceased." 12

The Union's recruitment of African-American soldiers only escalated the unwillingness of some Irishmen to fight. In March 1863, only a few months after the devastating loss of life at Fredericksburg, the Irish American produced an article that exemplified the Irish's extreme racism. Referring to a New York Tribune article on African-American soldiers under General David Hunter's Department, the Irish paper wrote, "if the Tribune people were not so painfully afflicted with nigromania (or "nigger on the brain," as George Francis Train calls it), they would be aware that 5,000 half savage, undisciplined negroes are the most unlikely material to ensure success where 50,000 disciplined whitemen, led by able Generals, and backed by a powerful fleet, have effected absolutely nothing."13 New York's Irish Catholic opposition to the direction of the war was also voiced in the New York's Freeman's Journal when it proclaimed that, "When the President called upon them to go and carry on a war for the nigger, he would be $\mathrm{d}-\mathrm{d}$ if he believed they would go.” New York’s Democratic governor Horatio Seymour supported this and warned Republicans, "Remember this - that the bloody and treasonable doctrine of public necessity can be proclaimed by a mob as well as by a government." ${ }^{14}$ Rhetoric such as this added to the growing tension between anti-war Democrats and Radical Republicans. These

\footnotetext{
${ }^{12}$ Irish American, October 11, 1862.

${ }^{13}$ Irish American, March 7, 1863; In this article, General David Hunter is seen as an incapable general. This may have been done purposely by the editors of the Irish American due to the fact that General Hunter had previously claimed Irishman Thomas Francis Meagher was drunk during the Battle of Antietam.

${ }^{14}$ James M. McPherson, Battle Cry of Freedom: The Civil War Era (New York: Oxford University Press, 1988), 609.
} 
newspapers appealed to New York's Irish soldiers, who felt as though their efforts and sacrifices were going unnoticed and underappreciated while African Americans gained widespread acclaim without stepping on the battlefield.

The disillusionment and animosity surrounding the changing war aims left Irish Americans in New York more focused on assisting those in their ethnic communities. As has been demonstrated, the cost of the Northern war effort throughout 1862 dramatically altered the lives of Irish Americans. After the heavy losses at Antietam and Fredericksburg, Irish Americans were faced with "tens of thousands of orphans whose fathers had given their blood to this country." 15 Many orphaned Catholic children in New York fell under the care of the Catholic Orphanage in Brooklyn, however this was destroyed by fire in the fall of 1862 . Therefore, many children were left without a place to stay. Consequently, many of these children came under the care of the Children's Aid Society, however Irish leaders became disturbed by this because they viewed the Society as a Protestant agency eager to convert Catholic children away from their faith. $^{16}$

Throughout the Civil War Era, Irish Americans turned to their ethnic and religious identity to assist orphaned children in New York City. In December 1862, in the midst of Irish casualties and disillusionment, Irish community leaders like Richard O’Gorman met with Archbishop John Hughes to organize the Catholic Protectory, officially known as The Society for the Protection of Destitute Roman Catholic Children in the City of New York. In May 1863, the new institution opened its doors in an attempt to assist the large number of Catholics among

\footnotetext{
${ }^{15}$ Edward K. Spann, "Union Green: The Irish Community in the Civil War," in The New York Irish ed. Ronald H. Bayor and Timothy J. Meagher (Baltimore: The Johns Hopkins University Press, 1996): 202.

${ }^{16}$ George Paul Jacoby, Catholic Child Care in Nineteenth Century New York: With a Correlated Summary of Public and Protestant Child Welfare (Washington, D.C.: The Catholic University of American Press, 1941), 73.
} 
the city's vagrant population. ${ }^{17}$ The institution made it clear that it was not formed to be a reformatory for juvenile delinquents but rather a protectory designed to give shelter and care to the children of the streets who are "in circumstances of want and suffering, of abandonment, exposure or neglect, or of beggary." ${ }^{" 18}$ The institution also provided a wonderful example of how Irish Catholics remained invested in interests that benefited their own beliefs. By the end of its first year as an institution, the Protectory provided a home for over a thousand children and was funded entirely by annual contributions and donations. ${ }^{19}$

New York Irish Americans at home and in the army continued to rally behind their ethnic and religious identity by organizing other relief and aid societies to the unfortunate. In the spring of 1863, Irish-American communities throughout the North united together to raise money for the relief of the suffering poor of Ireland. As was the case in the 1840s, those home in Ireland were threatened yet again by famine. Poor harvests for three consecutive years left many destitute. In response to the threat, relief communities that were previously established to channel funds to the homeland were reactivated. The Irish population in the United States, many of whom were famine victims themselves, understood the devastating struggle and established Irish Relief Funds all across the North. ${ }^{20}$ Even though assistance came from multiple countries, the Irish in the United States were by far the biggest providers. In August 1863, the Irish American newspaper reported that the United States had raised over $£ 20,000$ for Ireland’s famine relief. $^{21}$

\footnotetext{
${ }^{17}$ Dolan, The Immigrant Church, 138.

${ }^{18}$ Jacoby, Catholic Child Care in Nineteenth Century New York, 126.

${ }^{19}$ Spann, "Union Green: The Irish Community in the Civil War," 202; Jacoby, Catholic Child Care in Nineteenth Century New York, 128.

${ }^{20}$ Spann, "Union Green: The Irish Community in the Civil War," 202.

${ }^{21}$ Irish American, August 29, 1863.
} 
Irish soldiers in the Union Army were also quick to provide assistance for the struggling communities back in Ireland, with support even coming from the former commander of the Army of the Potomac and future Democratic Presidential candidate, George B. McClellan. In April 1863, McClellan spoke to a crowd at New York's Academy of Music in an attempt to gain funds for the struggling Irish. The beloved leader stated:

I have strong and peculiar reasons for feeling an intense sympathy for and interest in all that relates to Ireland and the Irish [Great applause]. I sprung myself from a kindred race. I have often seen the loyalty of the Irish to their Government and to their General proved. I have seen the green flag of Erin borne side by side with our own Stars and Stripes through the din of battle. [Cheers]. I have witnessed the bravery, the chivalry, the devotion of the Irish race, while I was a boy, on the fields of Mexico, and in maturer years on the fields of Maryland and Virginia [Loud cheers]. It has often been my sad lot, pleasant withal, to watch the cheering, smiling patience of the Irish soldier while suffering from disease or ghastly wounds; and I have ever found the Irish heart warm and true. [Cheers]. ${ }^{22}$

Soldiers throughout the Union Army rallied behind the former general, and the donations they made to the relief fund were recorded in Irish American newspapers of the time. Members of the largely Irish 42nd New York Infantry, Tammany Regiment, raised a total of $£ 493.50$ with donations coming from officers and privates alike. ${ }^{23}$ While many Irish soldiers fought for the Union to support their families, their donations to the poor of Ireland demonstrate the important role ethnicity played on the lives of Irish-American soldiers.

The Irish-American community in New York City did more to show their support for the suffering of the Emerald Isle. In April, Irishwomen worked diligently to raise funds for famine relief at the Irish Ladies' Patriotic Fund Ball. Prominent Irishmen like Archbishop John Hughes, Colonel Robert Nugent, Colonel Patrick Kelly, and other officers of the Irish Brigade rallied Irish Americans to the cause. These Irish Americans were all too familiar with the devastating consequences the famine had on their lives. Even as many were left to deal with the great loss

${ }^{22}$ Daily National Intelligencer, April 9, 1863.

${ }^{23}$ Irish American, May 9. 1863. 
and tragedy of the Civil War, they chose to rally to the aid of their fellow Irish men and women back home. Through the efforts of Irishwomen, their fundraiser ball raised approximately five to six thousand dollars. ${ }^{24}$ These efforts, along with the fundraising rallies before them, demonstrate that even as disgust for the war reached a peak, Irish Americans in New York became more united behind their ethnic identity through events that were distinctly linked to their Irishness.

Irish American communities of the Northeast also worked to assist the needs of the ethnic group in America, particularly the needs of women. As shown earlier, Irishwomen made up a large part of the poor working-class population of New York and other parts of the North. The Civil War only increased the opportunities for female labor in the city. Due to the conflict, labor shortages were created and the wartime industrial expansion left other opportunities for Irish Catholic women of the poorer classes. However, this meant that these women often needed assistance, especially after many of their husbands had enlisted to fight for the Union. ${ }^{25}$ By early 1863, many Irish women lost loved ones to the conflict and were faced to raise their children and take care of other family members alone. Because of this, in late 1863, the Working Women's Protective Union was formed. Irish community leader and judge, Charles Patrick Daly, headed the organization. Throughout the war, this Union provided support for seamstresses and other working-class women. While ethnicity remained a critical part to enact these efforts, their solidarity as working-class women was also a key factor in seeing this Union come to fruition. Its success continued when in 1865, it helped to form the first known Catholic day nursery for working mothers. ${ }^{26}$

\footnotetext{
${ }^{24}$ Irish American, April 25, 1863.

25 James J. Kenneally, The History of American Catholic Women (New York: Crossroad Publishing Company, 1990), 83.

${ }^{26}$ Hasia R. Diner, Erin's Daughters in America: Irish Immigrant Women in the Nineteenth Century (Baltimore: Johns Hopkins University Press, 1983), 78, 180n. 14.
} 
In the midst of disillusionment, Irish Americans in the field and on the home front stood united behind their ethnic identity. As St. Patrick's Day approached, Meagher planned to use the holiday to raise morale in the Irish Brigade. A committee of officers was formed to collect money and prepare for the holiday. On March 17, 1863, Father Willet held Mass for the members of the Brigade and after the service, chaplain of the Excelsior Brigade Father Joseph B. O'Hagan preached a sermon to the men in attendance. While the religious ceremony was important to the members of the Irish Brigade, few native-born Americans highlighted this fact, which shows that these two groups defined Irish ethnic identity differently. After the important religious service was completed, the well-planned festivities commenced in an attempt to uplift the spirits of Irish soldiers through a celebration of their "time-honored national anniversary."

The Irish units in the Army of the Potomac took the day seriously and invited their fellow Union soldiers to partake in the festivities. In the weeks before the event, the Irish Brigade's quartermaster was sent to Washington D.C. to secure the necessary supplies for the extravagant banquet that the men raised money for. In total, the Quartermaster acquired no less than thirtyfive hams, a side of roasted ox, a pig stuffed with boiled turkeys and countless chickens, ducks, and small game. As many native-born soldiers pointed out after the affair, the Irish did not forget the alcohol, with eight baskets of champagne, ten gallons of rum, and ten gallons of whiskey stockpiled for the special day. On March 16, a committee convened and decided that Captain Gosson and Captain Hogan were the most qualified to mix the alcoholic punch. Unfortunately, the men worked so hard at their task that they "both felt overpowered by their labours and had to be relieved from duty" due to their frequent tests to perfect the drink. ${ }^{27}$ While the spiced-rum punch was popular among Irishmen and native-born soldiers alike, the highlight of the celebration was the activities scheduled throughout the day. These included a sack race, a race

\footnotetext{
${ }^{27}$ Conyngham, The Irish Brigade and its Campaigns, 253, 183-184.
} 
for a greased pig, climbing a greased pole for ten days leave, a mock dress parade, and a horse race. ${ }^{28}$ Even though the joy and excitement of St. Patrick's Day allowed many Irishmen to forget the drudgery of war, for many it would be the last time they celebrated their important holiday.

Even with the celebration of St. Patrick's Day and the recruiting attempts of General Meagher, the Irish Brigade faced the spring of 1863 with depleted numbers. In May, at the Battle of Chancellorsville, the Irish Brigade entered the conflict with only 520 men. Positioned to support the 5th Maine Artillery Battery, they saw less action than in previous battles and their casualties totaled 102 men. While this was far less casualties than the Brigade was used to, it reduced the total force to 418 men, which was less than half the size of a full infantry regiment. ${ }^{29}$ After facing nativist prejudice, disillusionment, and the rising number of casualties, Irish Americans decided that their needs and hopes as an ethnic group outweighed their new identities as Americans. New recruits for the Irish Brigade became scarce as enthusiasm for the war continued to wane among Irish communities in the North. ${ }^{30}$

After Chancellorsville, Meagher feared his Irish Brigade would be disbanded and combined with non-ethnic units, and after further attempts to solicit Federal aid in recruitment failed, the general tendered his resignation and the War Department approved. ${ }^{31}$ Meagher's resignation was viewed as a necessary and honorable response to a prejudice administration. The New York Irish American reported that "although the Irish Brigade had been in every engagement that has been fought, and has left a record that they are proud of, which has been

\footnotetext{
${ }^{28}$ Daniel George MacNamara, The History of the Ninth Regiment, Massachusetts Volunteers Infantry, Second Brigade, First Division, Fifth Army Corps, Army of the Potomac, June 1861-June 1864 (Boston: E. B. Stillings \& Co., Printers, 1899), 278.

${ }^{29}$ Conyngham, The Irish Brigade and its Campaigns, 197-199. Attrition caused the average size of a regiment to be well under 1000 men by this point in the Civil War.

${ }^{30}$ By 1863, bounties rather than Irish nationalism or Catholic pride was what called Irish Americans into service for the Union. Randall Miller offers the best analysis on this in his work "Catholic Religion, Irish Ethnicity, and the Civil War," in Religion and the American Civil War, ed. Randall M. Miller, Harry S. Stout, and Charles Reagan Wilson (New York: Oxford University Press, 1998) 277-279.

${ }^{31}$ Conyngham, The Irish Brigade and its Campaigns, 200.
} 
noticed all over the world...their own Government has never taken any notice of them." ${ }^{32}$ Members of the 116th Pennsylvania stated that they lost a leader who they "would have followed to death, if necessary" and the United States with his resignation, lost "one of its most patriotic generals, one of its most daring soldiers, and the army one of its brightest ornaments." ${ }^{\prime 33}$ After two years of sacrifice for the Union, the Irish felt as though native-born Americans purposely ignored their efforts.

Meagher's resignation and the large loss of life left the Irishmen dejected but their ethnic identity remained strong and united them throughout 1863 . With so few men, the regiments that made up the Irish Brigade were left to reorganize. The three New York regiments were consolidated into three two-company battalions. Similarly, the 116th Pennsylvania Infantry was so under strength that the Army ordered it into a four-company battalion. The regiment's commander, Irish-born Lieutenant Colonel St. Clair A. Mulholland accepted the order to ensure the men stayed in the Irish Brigade. However, this move meant Mulholland was forced to take a reduction in rank and pay to remain with his men. Mulholland's move is a clear demonstration of the important role ethnicity played among the men in the Irish Brigade. As the soldiers marched north to Gettysburg, Pennsylvania, Colonel Patrick Kelly of the 88th New York, numbering approximately 500 men only, led them. Their numbers were so few that one officer of the Irish Brigade noted that they were "now a brigade in name only." ${ }^{34}$ Even with so few men, the Brigade was ordered into the thick of the fight at the Wheatfield and Devil's Den. Before they advanced however, Father Corby appealed to the men's Catholicism with a general absolution.

Economic and social unrest led New York laborers, many of them Irish, to meet in March 1863 and discuss their disapproval of wages and inflation. 6,000 laborers joined together to form

\footnotetext{
${ }^{32}$ Irish American, February 28, 1863.

${ }^{33}$ Conyngham, The Irish Brigade and its Campaigns, 204.

${ }^{34}$ Conyngham, The Irish Brigade and its Campaigns, 413-415.
} 
a union and demanded that their organization include white males only. Shortly after, 3,000 New York longshoremen walked off their jobs to protest working conditions. The situation escalated when African-American workers were called in as strikebreakers. This caused many Irishmen across New York to feel as though their labor and efforts were not appreciated. The use of African Americans as strikebreakers added to the already high tensions over black enlistment in the Union Army and the emancipationist war aims. All these issues caused Irish Americans in New York to feel as though their efforts and support for the Union were not appreciated and that African Americans now held the same social status as them. ${ }^{35}$

Catholic working-class Irishwomen were also affected negativity by the economic and social unrest of New York. Common employment advertisements published in newspapers such as the New York Times asked for workers as long as they were not Catholics. One example read, "A Cook-Wanted, as cook in a small family, a German, English, Scotch or Protestant Irish woman..." A similar advertisement requested the services of a nurse and seamstress, noting "Protestants, English, or Germans preferred." ${ }^{36}$ Another posting requested, "a middle-aged woman, capable of taking care of two small children" and specifically specified, "No Irish need apply." ${ }^{37}$ Labor advertisements like these demonstrate the continued nativism towards Irish Americans and show that the sacrifices of the Irish Brigade and other Irish soldiers seemed to have little impact on the native-born population of New York. ${ }^{38}$ It also demonstrates that even as Irishwomen hoped to be seen the same as other working-class women, their identity as Catholics was an important factor in how native-born Americans perceived and treated the ethnic group in the United States.

\footnotetext{
${ }^{35}$ Noel Ignatiev, How the Irish Became White (New York: Routledge, 1995), 112.

${ }^{36}$ New York Times, January 16, 1863.

${ }^{37}$ New York Times, July 7, 1863.

${ }^{38}$ Advertisements like these can be found in nearly every issue of the New York Times throughout the war years.
} 
Although large numbers of Americans continued to volunteer for service, by the summer of 1862 , the country failed to fulfill the manpower demands for the Union war effort, which caused controversy and outrage, particularly among Irish Americans. Because of this, Congress passed the Militia Act of 1862 and the Enrollment Act of 1863. The Militia Act led to state drafts and the Enrollment Act, also known as the Conscription Act, resulted in the federal draft. Both acts were extremely controversial, particularly among the Irish-American community. Some viewed the acts as unconstitutional and even un-American. The Union no longer seemed to be a nation of citizen soldiers and private citizens who joined voluntarily to defend American freedoms. New York's Irish community seemed particularly worried about being drafted. The New York Irish American reported, "a large number in this city are not registering their names, and will not vote, for fear of being drafted." Even though readers were assured that "The poll lists have no connection with those prepared for the drafting Commissioners," the newspaper's clarification demonstrates that some Irish were worried of being drafted. ${ }^{39}$

The government sensed how controversial the Militia Act would be, therefore they assured that if states could meet their quotas there would be no need to put the law into effect. Each year, every district in every northern state received a statement explaining how many soldiers it needed to supply to the army based on the number of military aged males in their population. If they met this quota, the draft would not be enacted, however if they failed, the Secretary of War could draft militiamen from that state into Federal service for a nine-month period. ${ }^{40}$ Nearly every district in the country had complaints about the hated law, with some charging that Republicans purposely placed heavier quotas on Democratic districts. ${ }^{41}$

\footnotetext{
${ }^{39}$ Irish American, November 1, 1862.

${ }^{40}$ McPherson, Battle Cry of Freedom, 492-494.

${ }^{41}$ Eugene C. Murdock, One Million Men: The Civil War Draft in the North (Madison, WI: The State Historical Society of Wisconsin Madison, 1971), 6-7.
} 
Due to the unpopularity of the draft, communities turned to a bounty system, which offered a fee to volunteers that they received once they enlisted. The system was encouraging, with prices ranging from $\$ 50$ to $\$ 1000$. While logical in theory, the bounty system quickly developed into a scandalous practice. Rather than demonstrate their loyalty to the Union or their worth in battle, some men exploited the system for financial gain. By the time of the federal draft in 1863 , some men developed the manipulation of bounties into a fine art—by enlisting in a regiment, gathering the bounty, deserting, and then repeating the practice in a different district. ${ }^{42}$ The Army eventually addressed the problem by transporting bounty soldiers under armed guard to the frontlines, however some soldiers continued to escape and reenlist for bounties elsewhere. An anonymous author from the largely Irish 99th New York described his experience with bounty jumpers during his time as a guard at Elmira Prison in New York. In a letter published in the Irish American, he wrote, "We are still in the same place, and doing the same dutyguarding the 'Johnny Rebs,' substitutes, and 'bounty jumpers,' who are in hospital. Some of these fellows have made a trade of cheating the government, by enlisting and getting Uncle Sam's greenbacks, and then they skedaddle the first chance they get." The anonymous writer continued by saying, "Very often they pretend to be sick, in order to be sent to the hospital. Some jump off the cars when on the way to the front, and are fired at by the guards and wounded before they see the enemy. There are many such cases now in the hospital here. The city is full of bounty jumpers and recruiting agents, who try to enlist men, and afterwards try to get them away for a consideration." ${ }^{\prime 3}$

\footnotetext{
${ }^{42}$ For an in depth look into the fraudulent and rampant speculation of the bounty system, see Brian P. Luskey, Men is Cheap: Exposing the Frauds of Free Labor in Civil War America (Chapel Hill: The University of North Carolina Press, 2020).

${ }^{43}$ Irish American, October 7, 1864.
} 
Recruiting Irishmen into Union service became more difficult as the war progressed. This left recruiters to draw attention to the significant bounties men could earn rather than spotlight their ethnic heritage. Early Irish recruitment posters appealed to ethnic lineage by placing words like "Irish" and "Erin" in big, bold letters and having images of harps and shamrocks overtake the page. As the war dragged on, however, these words and images became smaller and the amount of money a soldier could receive took their place. Although a recruiting poster for Corcoran's Irish Legion displayed an Irish harp, nearly half the poster was taken up with state and government bounties (Figure 5). Later posters for Irish units such as Mulligan's Brigade highlighted the opportunity to receive a $\$ 402$ bounty and avoid the draft if they joined. This shift in the design and overall image of Irish recruitment posters demonstrates the importance money played in the overall willingness for men — particularly poor Irishmen — to join the Union Army. While this does not mean that Irish heritage was no longer significant, it shows that their ethnic identity became less important, while their identity as soldiers loomed larger so they could avoid the draft and earn a substantial amount of money in the process.

The United States government looked for other ways to encourage immigrants to volunteer for Union service. The government understood the desire of Irishmen and many other immigrant groups to become American citizens. Therefore, on July 17, 1862, Congress passed a bill that allowed any alien twenty-one years or older who volunteered for military service and was honorably discharged to become a citizen of the United States ${ }^{44}$ Although this could hold important post-war advantages for Irish Americans, the Union manpower problem largely remained, which proves the widespread disillusionment among the immigrant group during this time. Unfortunately, this lack of support resulted in the Irish-American community facing

\footnotetext{
${ }^{44}$ Tyler Anbinder, Nativism and Slavery: The Northern Know Nothings and the Politics of the 1850s (New York: Oxford University Press, 1992), 121.
} 
frequent attacks from the native-born population, who argued that the Irish were against the Union and the United States. New York Irish Americans expressed their frustration with nativeborn Americans who seemed to argue that the Irish were expected to give larger numbers of men to the war effort or they would be labeled as disloyal to the Union. "An Irishman" writing in the Irish American reminded his readers of the large number of his ethnic group in the Union Army. He then asked "what Republican papers mean by singling out Irishmen to fight the battles of America? It is not rather a stigma on this party that it should be forced to call upon foreigners, and especially upon Irishmen, whom they have always denounced as inferior to 'niggers,' to march 'to victory and glory?',45

By 1863, the need for new recruits in the Union Army was high, and newly arriving immigrants offered an ideal solution. Due to the Enrollment Act, prospective substitutes could receive large sums of money and private substitute brokers sprung up in major Northern cities. In addition to the money earned by signing up as a substitute, bounties were also offered, which assisted to further encourage new recruits. These incentives led substitute brokers and other agents looking to make money off potential enlistees to work in close proximity to the northern ports. Joseph Burnley, a British diplomat based in New York recalled the "rascalities and swindling practices of the bounty brokers," who work within a "distance from the Emigration Depot to this office is about 400 yards, and the number of recruiting and enlisting rooms and booths within that distance is about 7 or $8 \ldots$ In the neighborhood of these booths and rooms brokers and runners swarm; and the unhappy emigrants who land here are necessarily obliged to run the gauntlet of these mantraps and harpies."46

\footnotetext{
45 Irish American, October 11, 1862.

${ }^{46}$ James J. Barnes and Patience P. Barnes, The American Civil War Through British Eyes: Dispatches from British Diplomats, Volume 3, February 1863-December 1865 (Kent, OH: Kent State University Press, 2005 ), 251.
} 
As the war dragged on and Irish disillusionment continued, Congress again called on Americans to submit to the draft, but worked to close loopholes and inequalities of the bounty system. Aware of the unpopularity and controversy surrounding the draft, politicians included exclusionary clauses in the 1863 Enrollment Act. Under this revision, all fit male citizens and aliens intent on becoming citizens between the ages of twenty and forty-five were liable for military service. Section 13 of the act included means by which a draftee could be excluded from service, which was done in an attempt to make the call to arms more democratic. All men called to service could legally avoid the army by securing an exemption or by finding a substitute to take his place. The other possibility was to pay a $\$ 300$ commutation fee, which allowed a draftee to pay to escape service. Looking at the problems associated with bounties, lawmakers set the price to prevent the cost from soaring beyond the reach of many draftees. Although this may have been done in good conscious, those of the working class saw things differently. For many, $\$ 300$ was half a year's wages, and therefore just another example of the wealthy forcing the poor to do their bidding. ${ }^{47}$ One Irish American wrote to his sister in anger, stating, "the War is a complete humbug. A war of speculation, to a certain class of men, but to the private soldier, destruction. ${ }^{48}$ For these Irish Americans, their identity as laborers and soldiers loomed larger than their ethnic identity.

Working-class Irish Americans in particular found themselves outraged by the perceived injustice that the exemption clause presented. New York's Irish and Catholic newspapers were angry over the new sections put into practice. The Irish American voiced their opposition to the exemption fee in an article titled, "The Inequality of the Present Conscription Law" when it

\footnotetext{
${ }^{47}$ Murdock, One Million Men, 6-7; Peter Levine, "Draft Evasion in the North during the Civil War, 1863-1865," The Journal of American History 67, no. 4 (March 1981): 816.

${ }^{48}$ Ron Gancas ed., Dear Teres: The Civil War Letters of Andrew Joseph Duff and Dennis Dugan of Company F, the Pennsylvania Seventy-Eighth Infantry (Chicora, PA: Mechling Bookbindery, 1999), 131.
} 
stated, "Exemptions have been multiplied until large classes are not only relieved from military duty but also from giving any equivalent for such relief. They include numerous officials and other classes who have no claims to exemption beyond those which belong to every citizen engaged in useful pursuits. ${ }^{39}$ The Metropolitan Record argued that while abolitionists like William Lloyd Garrison and Henry Ward Beecher denounced Peace Democrats and Copperheads, they "are not the men who are ready to put themselves in jeopardy, so long as they can purchase exemption from the draft by the payment of three hundred dollars worth of greenbacks." ${ }^{50}$ Those opposed to exemption created a parody to the popular song "We Are Coming, Father Abraham.” The sarcastic lyrics captured the sentiment of many Irish Americans with the new words stating: "We're coming, ancient Abraham, several hundred strong / We hadn't no 300 dollars and so we came along / We hadn't no rich parents to pony up the tine / so we went unto the provost and there we mustered in. ${ }^{, 51}$ The Irish community felt as though the draft disproportionally forced them into the army.

Even though the $\$ 300$ exemption fee outraged Irish Americans in the North, records show their anger is partially unfounded. Contrary to Irish views of the time, very few immigrants served in the army due to the draft according to historian Tyler Anbinder. Many immigrants avoided the draft by claiming exemption, taking out loans, or ignoring the call and accepting the possibility of arrest and imprisonment. Out of these immigrants, Irishmen were the most likely to desert rather than report when drafted. Furthermore, in the 1863 draft, approximately half of the men who entered the army were immigrants who enlisted voluntarily as substitutes. This is

\footnotetext{
${ }^{49}$ Irish American, January 17, 1863.

${ }^{50}$ Metropolitan Record, June 13, 1863.

${ }^{51}$ Levine, "Draft Evasion in the North during the Civil War," 816.
} 
evident when looking at New York City's Fifth Draft District, where immigrants made up seventy-seven percent of the 1863 substitutes. ${ }^{52}$

Perceived injustices made by native-born Americans towards the Irish throughout the Civil War and before, caused the ethnic group to become more opposed to the draft. New Yorkers expressed their aggravation in the popular press. James McMaster, editor of the Catholic Freeman's Journal proclaimed, "when the President called upon them to go and carry on a war for the nigger, he would be $d \_d$ if he believed they would go." Irish-American editor of the Metropolitan Record, John Mullany expressed opposition to the draft in the form of a poem. The poem explained sarcastically that,

Each soldier must be loyal and his officers obey, / Tho' he lives on mouldy biscuits and fights without his pay; / If his wife at home is starving he must not be discontent, / Tho' he waits six months for "greenbacks," at forty-five per cent.

Moreover if you're drafted, do not refuse to go, / You're equal to the Nigger and can make as good a show; / When you are in a battle, to the Union be true, / But don't forget the Nigger is as good a man as you. ${ }^{53}$

New York's Democratic Governor Horatio Seymour, supported these claims and asserted,

"Remember this - that the bloody and treasonable doctrine of public necessity can be proclaimed by a mob as well as by a government." 54

Just as the Governor predicted, the most violent response to the federal draft erupted in New York City in July 1863. Over a five-day period, many Irish Americans and other groups of New Yorkers, voiced their opposition to emancipation, the Republicans, nativism, and the draft. New York military officials were unprepared to meet the violence that engulfed the city because

\footnotetext{
52 Tyler Anbinder, "Which Poor Man's Fight? Immigrants and the Federal Conscription of 1863," Civil War History 52, no. 4 (December 2006): 348, 368-369.

${ }_{53}^{53}$ Metropolitan Record, May 16, 1863. For the full poem, see Appendix B.

${ }^{54}$ Horatio Seymour, Public Record: Including Speeches, Messages, Proclamations, Official Correspondence, and Other Public Utterances of Horatio Seymour from the Campaign of 1856 to the Present Time, eds. Thomas M. Cook and Thomas W. Knox (New York: I. W. England, 1868), 120.
} 
they were partially preoccupied by the Battle of Gettysburg and their failure to recognize the potential threat of the Irish Protestant's annual July 12 celebration for William of Orange's Protestant victory over James II's Catholic forces at the Battle of Boyne in $1690 .{ }^{55}$ While this caused various degrees of tension from year to year, the economic, political, and religious control Protestants held in the United States in 1863 added to the disgruntlement of Irish Catholics.

These feelings proved to be detrimental to the stability of New York City and helped ensure the outbreak of violence. In response to the 1863 draft call, Governor Seymour promised to fill the state's quotas with volunteers, and even if that proved impossible, he pledged to go to court to challenge the legality of federal conscription. New Yorkers were therefore surprised, when on Saturday July 12, they read the names of the first draftees in the city papers. On the weekend of July 11 and 12, New York laborers, mechanics, and urban poor expressed their outrage over the draft. They began their protest early Monday morning by refusing to go to work, marching toward the draft offices, and tearing telegraph lines and other means of communication down. The rioters burned down draft offices, with the help of Irish fire companies, and continued to march around various parts of the city, while gathering other laborers in an attempt to bring the city's war production to a standstill.

As the riots progressed, the participants of the riots varied and changed. Monday's protesters were a mixed group of native-born Americans and immigrants, ranging from artisans to laborers. The violence on Monday included the beatings of police officers and of African Americans who were seen by some as the blame for the war and the draft. However, historian Iver Bernstein explains that by the afternoon, a core group within the rioters began to separate

\footnotetext{
55 Adrian Cook, The Armies in the Streets: The New York City Draft Riots of 1863 (Lexington: The University Press of Kentucky, 1974), 21-22.
} 
themselves from the others who continued the violence. While multiple fire companies participated in the violence in the morning, by the afternoon they worked to end and prevent additional destruction. Many German-American protestors ended their rioting and set up patrols to protect their neighborhoods. ${ }^{56}$ As the riots increased in strength between Tuesday and Thursday, their dynamics shifted. Many of the skilled laborers that took part in the violence on Monday chose to stay home, and left predominately Irish Catholic unskilled laborers and factory workers to remain. The individuals left, were much more violent and chose to attack Republicans and African Americans, who they saw as the cause of the Civil War and its continuation. Police officers and soldiers were also targeted because they were the enforcers of the laws that were perceived as unjust to the poor of New York. Many of these individuals were brutally beaten, sometimes to death, while others were drowned, hanged, and mutilated by the rioters. The shocking violence continued until Friday, July 17, when military forces returning from the Battle at Gettysburg and joined city police to subdue the rioters.

Although ethnicity became less important to Irish Americans as the violence intensified, native-born Americans were sure to link ethnic identity to the draft riots. Reactions to the draft riots negatively impacted the way New York Irish military service to the Union was remembered. New York journalist George Templeton Strong was sure to single out the Irish when he wrote, "The Germans have behaved well and kept quiet," while "Every brute in the drove was pure Celtic—hod-carrier or loafer. ${ }^{" 57}$ A female New Yorker expressed her aggression and anger when she wrote: "Nothing would satisfy me but pistols. Non-resistance to Irish savages howling for one's life-blood, seemed the feeblest subterfuge of cowardice." Due to the

\footnotetext{
${ }^{56}$ Iver Bernstein, The New York City Draft Riots: Their Significance for American Society and Politics in the Age of the Civil War (New York: Oxford University Press, 1990), 17-42.

${ }^{57}$ George Templeton Strong, Diary of the Civil War, 1860-1865, ed. Allan Nevins (New York: The Macmillan Company, 1962), 343, 335. Merriam-Webster defines hod carrier as "a laborer employed in carrying supplies to bricklayers, stonemasons, cement finishers, or plasterers on the job."
} 
action of the rioters, she explained, "The sight of an Irish man or woman became so odious to me, that I could not treat them with external decency." 58 The New York Times reported on the rioters and singled out the Irish participants. The newspaper wrote that "the City were at the mercy of a mob of Irishmen and thieves. ${ }^{, 59}$ In the midst of Irish violence and declining Irish support, native-born Americans considered the ethnic group's actions in the draft riots as a betrayal, and therefore renewed their stereotypical opinions of the Irish Catholics. As one nativeborn American put it, "Paddy has not done much to entitle his race to our sympathy and affection during the last six months. ${ }^{.60}$

Rather than chastise the ethnic group's participants, prominent New York Irish Americans defended the actions and motivations behind the Irish rioters. Irish communities linked their declining assistance for the Union war effort as a show of support to their fellow Irish countrymen. The New York Irish American argued that the Lincoln administration was warned of "the danger they were risking, and the outbreak of popular resentment and opposition which the obnoxious character of the law would be certain to provoke." Despite this, the Republicans "heeded neither advice nor warning; and the deplorable results...are all that their disregard of the plainest dictates of common sense has produced." ${ }^{61}$ While Archbishop John Hughes insisted the rioting was wrong, he also argued that the week's chaos was partially due to unjust Republican policies and anti-Irish Catholic prejudice. The New York Tribune's editor Horace Greely, who claimed all those arrested were exclusively Irish, particularly outraged Hughes. Although he did not doubt only Irishmen were arrested, Hughes argued that this was

\footnotetext{
${ }^{58}$ Sarah Hopper Emerson ed., Life of Abby Hopper Gibbons: Told Chiefly through Her Correspondence (New York: G. P. Putnam's Sons, 1897), 58-59.

${ }^{59}$ New York Times, July 25, 1863.

${ }^{60}$ Strong, Diary of the Civil War, 371.

${ }^{61}$ Irish American, July 18, 1863.
} 
done because they were "innocuous victims of our municipal laws." ${ }^{92}$ On July 16, Hughes spoke to a crowd of Irish Catholics and proclaimed, "If you are Irishmen, and the papers say the rioters are all Irishmen, then I also am an Irishman, not a rioter, for I am a man of peace. If you are Catholics, as they have said, probably to wound my feelings, then I also am a Catholic.... They call you rioters, and I cannot see a riotous face among you. ${ }^{963}$ While Hughes and the editors of the New York Irish American do not speak for the entire Irish Catholic population, their popularity is indicative of how Irish communities felt about the draft riots. A sense of loyalty to their ethnicity led many Irish Americans to enlist in the Northern armies and now this same sense of responsibility caused them to oppose the Union. Loyalty to their ethnic heritage caused nativist antagonism to reemerge and even increase throughout the Civil War.

The Irish community was equally outraged by the fact that nativists ignored the honorable deeds of Irish Americans during the violent riots. Native-born Americans were either unwilling or unaware that Irish-born Paddy McCafferty helped rescue young children from the rioters who destroyed the Colored Orphan Asylum. Likewise, no mention was given to Irish American and former Irish Brigade officer, Robert Nugent who tried to enforce the draft. Even Irish-American Captain Henry O’Brien, who lost his life in an effort to protect New Yorkers, was ignored for his actions. While Irish Americans bore some of the blame for the violence of the riots, the ethnic group was angered by the fact they were seen as solely responsible. For the Irish, it seemed as though native-born Americans were unwilling to recognize their part in the riots and its cause and only chose to blame Irish Americans for the entire debacle. ${ }^{64}$

Like the previous year, 1863 ended with Irish disillusionment partially due to the unexpected death of Irish hero Michael Corcoran. The December death of the thirty-six year old

\footnotetext{
${ }^{62}$ Boston Pilot, July 25, 1863.

${ }^{63}$ New York Times, July 18, 1863.

${ }^{64}$ Bernstein, The New York City Draft Riots, 260-264.
} 
Brigadier General, apparently of a stroke, stunned the Irish-American community. The funeral service at St. Patrick's Cathedral was packed with grieving Irish men and women from across New York City. Irish-American newspapers, as well as the New York Herald and the New York Times, covered the somber service. Despite an inspiring eulogy by Thomas Francis Meagher, the Irish-American community was left to dwell on Corcoran's passing, and seriously question whether any Irishmen would be left to fight in a future war to liberate Ireland from England. This loss only increased the disillusionment among Irish Americans and reminded them of the changing war aims, economic insecurity, nativist prejudice, and the thousands of Irishmen who lost their lives in the Civil War.

Irish Brigade soldiers' frustration and disillusionment towards the war was seen when the men arrived home in New York on January 2, 1864. Rather than a joyous welcoming of native gratitude for their military service, the city streets were quiet and nearly empty but for the soldiers' families. The men imagined "the happiness of that day when we would march back through New York; of the welcome we would receive..." ${ }^{95}$ Instead, only brief mention was made in the newspapers of the return of the Irish Brigade's New York regiments. Native-born Americans had little reason to celebrate and welcome the influx of Irishmen into the city, especially after the riots in July. On the day of the Irish Brigades' return, diarist George Templeton Strong argued Governor Seymour "deserves the infamous place he will occupy in our history," due to his decision to remove police officials who criticized the rioters. ${ }^{66}$ The men of the Irish Brigade were frustrated by the "lukewarmness on the part of the authorities, who were openly and malignantly opposed to the national cause and its supporters, the officers of the Brigade, those who had served and those still in service..." Members of the Irish community

\footnotetext{
65 Boston Pilot, May 30, 1863.

${ }^{66}$ Strong, Diary of the Civil War, 389.
} 
organized a grand banquet to "welcome back to their homes, in a fitting manner, the faithful and brave men of the Brigade," which was attained by many. Despite this effort, the Irishmen were not consoled by the fact that they did "not have the municipal authorities to welcome" them back home after their "onerous, tiresome, exacting duties..."67

Even with disillusionment high, nearly every member of the tiny unit reenlisted with recruitment efforts gaining some success as well. This success was most likely due to the effectiveness of the bounty systems and reenlistment bonuses rather than an interest among Irish Americans to the Union war effort. Newly arrived Irish immigrant Thomas McManus wrote to his family, "by Gor' the bounty was very tempting and I enlisted the first day I came here." ${ }^{68}$ For soldiers already in the Irish Brigade, the sense of camaraderie and ethnic bonds, along with the large economic motivations, may have contributed to the large number of men who reenlisted. The number of reenlistments may also be a possible example of the growing divergence between civilians and soldiers of the ethnic group. One Irish soldier wrote of this divide when he stated, "It is discouraging for us to see so much disunion in the North." The soldier continued, explaining "their party politics and prejudices has caused a split between those in the field and those at home." ${ }^{69}$ Peter Welsh, an Irishman in the Irish Brigade held similar beliefs. Welsh actually supported the draft and stated, "the war will either be settled or the skulking blowers at home will have to come out and do their share of the fighting." ${ }^{, 70}$ Some soldiers could not be enticed to reenlist, however. One Irishman wrote home to his aunt telling her there was no need

\footnotetext{
${ }^{67}$ Conyngham, The Irish Brigade and its Campaigns, 426, 432.

${ }^{68}$ Quoted in Kerby A. Miller, Emigrants and Exiles, Ireland and the Irish Exodus to North America (New York: Oxford University Press, 1985), 360-361.

${ }^{69}$ Gancas, Dear Teres, 207, 219.

${ }^{70}$ Peter Welsh, Irish Green and Union Blue: The Civil War Letters of Peter Welsh, Color Sergeant, 28th Regiment, Massachusetts Volunteers, eds. Lawrence Frederick Kohl and Margaret Cossé Richard (New York: Fordham University Press, 1986), 110.
} 
to "be afraid of me being enticed to enlist again. Any inducements that they may see fit to hold out will not change my purpose in the least." ${ }^{\text {71 }}$

Even with tensions in New York City high in 1864, Irish Americans on the home front chose to express their ethnic heritage with a massive celebration on St. Patrick's Day. On March 17 , vendors stood at nearly every street corner offering shamrocks and miniature Irish flags to the spectators and cries of "The Flag of Old Ireland for one cent" rang throughout the city. ${ }^{72}$ As with the Irish Brigade's celebration of St. Patrick's Day the previous year, a solemn High Mass took place in St. Patrick's Cathedral. Reverend Francis T. Boyle announced that the money collected would be given to the Conference of St. Vincent de Paul for the relief of Irish poor. In his sermon he touched on the shared diasporic identity of his fellow country men and women when he said, "When famine came upon them [the Irish], if they were not a people of faith, they could never have upheld themselves in the hour of that dreadful calamity. Standing over the graves of their wives and children.... The hardy pioneer of the West puts pictures of Christ and His Mother on the walls of his cabin, and tells their history on his humble beads." Possibly hinting to the negative treatment of the Irish in America, he finished his sermon by stating that the Irish "have passed through the red sea of trial, but are still bound together in the common faith—Irish and Catholic!"73

After High Mass concluded, a massive parade through the streets of New York City commenced and the motivations and agenda of New York's Irish-American community became clear through the groups and societies that participated. Many Irish soldiers took part in the parade; some 600 men of the 69th New York Infantry in attendance, and another 400 men, led by Fenian John O'Mahony, of the 99th New York National Guard. Even though the streets were

${ }^{71}$ Gancas ed., Dear Teres, 294.

${ }^{72}$ New York Times, March 18, 1864.

${ }^{73}$ Irish American, March 26, 1864. 
filled with spectators, the Irish American proudly reported that there was a "total absence of cases of intoxication in the streets." This fact had much to do with the large amount of temperance associations that partook in the parade. One of these groups was the Temperance Cadets of the Visitation of the Blessed Virgin Mary, South Brooklyn who carried a banner reading, “All's right—Dad's sober.” The Father Mathew T.A.B. Society No. 2 of New York also carried green banners with the Maid of Erin, a gold harp, and Irish wolfhounds, along with the words, “There's not, within this lovely land, A fairer sight to see, Than those who march beneath our flag, In sober dignity." Along with these temperance men, the multiple New York Irish groups know as the Ancient Order of Hibernians participated in the parade. ${ }^{74}$

With the draft riots occurring only eight months prior to St. Patrick's Day, it is hard to believe native-born Americans had little problem with a massive gathering of Irish Americans in the streets of New York City. Even though the draft riot participants were not exclusively Irish Americans, they were blamed for the destruction and violence that rocked the city. This was something that both native-born Americans and Irish Americans were aware of when they planned the 1864 St. Patrick's Day festivities. In a New York Times article from February 28, the paper reported that many opposed the parade route and argued that the Irish should march "where their countrymen lived, and not among 'Republicans' and 'Know Nothings.",75 The Irish were aware of the tension that existed and worked diligently to make sure their 1864 celebration went on without a problem. On February 13, a convention of Irish Societies met to make arrangements for the upcoming St. Patrick's Day celebration. During this meeting, a committee was created to work with the military and the National Guard to ensure the festival would be

\footnotetext{
${ }^{74}$ Irish American, March 26, 1864.

${ }^{75}$ New York Times, February 28, 1864.
} 
handled responsibly. ${ }^{76}$ The large amount of temperance societies that registered to participate in the parade may have also been a key reason why native-born Americans were amenable to the Irish festival. The day after St. Patrick's Day, the New York Times reported, somewhat surprisingly, that, "The celebration of the anniversary of Ireland's Patron Saint was more general, yesterday, than on any former occasion. ${ }^{.77}$ Even though little opposition to the $1864 \mathrm{St}$. Patrick's Day festival was voiced, it was clear that Irish and native-born relations within the city were still fractured. The paper's tone the previous year was drastically different when it reported, "May we all live to see many more St. Patrick's days, and may they all be still more happy than the one we celebrated yesterday." ${ }^{.78}$ By 1864, this happiness and acceptance of ethnic tradition was absent in the city, and it would take many years for the feeling of March 1863 to be readopted by native-born Americans again.

1864 recruiting efforts demonstrated the diasporic ties among Irish communities that stretched transnationally. Even with trickery at the docks, there is little evidence to suggest Irishmen were 'duped' into joining the Union Army on their arrival. The sheer number of Irish already in the United States meant a constant flow of information across the Atlantic existed, and letters sent to family and friends in Ireland meant they were quickly informed of what service to the United States detailed. An 1864 newspaper article detailed the serious consideration the New York County Volunteers Recruiting Committee had in opening a recruiting station at the immigration depot, Castle Garden. Ultimately this did not happen because it would have a negative effect on immigration due to the fact that the, "letters of their friends in Ireland and Germany... would be immediately added to keep emigration from the country, and thus an injury inflicted on the industrial prosperity of the country exceeding a thousand fold the increased

\footnotetext{
${ }^{76}$ Irish American, February 13, 1864.

${ }^{77}$ New York Times, March 18, 1864.

${ }^{78}$ New York Herald, March 18, 1863.
} 
benefit in the way of additional recruits..." ${ }^{99}$ Because this would have ultimately discouraged prospective immigrants, the recruiting station at Castle Garden never came to fruition.

The general makeup and leaders of the Irish Brigade throughout the later years of the war also provide a key example of how important ethnicity was. Previous authors who have written on ethnic soldiers in the Civil War have claimed that Irish regiments tended to lose their ethnic identity as the war progressed. Historians like Ella Lonn and William Burton have used this as proof that the conflict "Americanized" these soldiers, however a close analysis of the Irish Brigade in the last two years of the war provides contrary evidence.$^{80}$ Although it was more common for the Irish Brigade to receive non-Irish soldiers later in the war, the fact that their leadership remained largely Irish challenges the notion that they lost their ethnic identity. After Meagher's resignation, four other Irish-born officers led the Irish Brigade in the last two years of the war.

Even with new recruits and reenlistments, as the fighting renewed in the spring, IrishAmerican spirits continued to decline. During the Battles of the Wilderness, Spotsylvania Court House, and Cold Harbor, the Irish Brigade lost over one thousand officers and men, which was nearly one third of their renewed strength. The heavy fighting of the Overland Campaign similarly thinned the ranks of the Irish Legion, which was comprised of four New York regiments that Michael Corcoran organized in the fall of 1862. In June, Colonel Patrick Kelly fell mortally wounded before Petersburg. Kelly had been with the Irish Brigade since the beginning of the war and commanded the Irishmen at Gettysburg. ${ }^{81}$ Upon hearing of his death, the Irish American newspaper reported "strong old veteran soldiers wept like children, and

\footnotetext{
${ }^{79}$ Irish American, July 23, 1864.

${ }^{80}$ See Ella Lonn, Foreigners in the Union Army and Navy (Baton Rouge: Louisiana State University Press, 1951); William L. Burton, Melting Pot Soldiers: The Union's Ethnic Regiments (New York: Fordham University Press, 1998).

${ }^{81}$ Conyngham, The Irish Brigade and its Campaigns, 457-459.
} 
wrung their hands in fury." ${ }^{" 82}$ After the nonstop campaigning, the Irish Brigade once again found itself with more dead on its rolls than living and the reduced numbers meant the men were temporarily consolidated into battalions and placed under new command. Although some of the Irishmen considered this an "ungracious and ungenerous measure," there was no one of sufficient influence left to plead their case for the retention of a brigade composed of a majority of Irishmen. Eventually, Colonel Nugent, who was appointed to forward the draft in New York, and several other officers heard of their struggle and managed to recruit a sufficient amount of men to replenish the regiments to their minimum numbers. Their recruiting efforts secured the existence of the original three New York regiments in the Irish Brigade for the remainder of the war, but the 28th Massachusetts and the 116th Pennsylvania Infantry Regiments sadly parted with the Irish Brigade and were assigned to the Second Division's First and Forth Brigades respectively. ${ }^{83}$

Irish disillusionment continued on the home front as well, with Irish community leaders using their Democratic identity to influence the ethnic group. Irish Peace Democrats in New York like Richard O'Garman and Daniel Devillin called for an immediate end to the war, even if it meant a permanent division of the United States ${ }^{84}$ Irish American John Mullaly, who was editor of the Metropolitan Record held similar sympathies with Peace Democrats. Mullaly used his newspaper to condemn emancipation, the draft, and the Republican Party as a whole. Beginning in June 1864, the newspaper changed its name to the Metropolitan Record and New York Vindicator. No longer carrying the subtitle, "A Catholic Family Paper," the newspaper became a secular sheet that supported the "principles of Jeffersonian Democracy" and identified

\footnotetext{
${ }^{82}$ Irish American, June 2, 1864.

${ }^{83}$ Conyngham, The Irish Brigade and its Campaigns, 467-468.

${ }^{84}$ Spann, "Union Green: The Irish Community in the Civil War," 208.
} 
as a "Democratic and family weekly." ${ }^{85}$ Under the new title, Mullaly continued to assault President Lincoln and the Republican Party. He argued that the true foe of liberty was not the Confederacy but rather Lincoln, "The arch conspirator against popular freedom," who made "his lair in the White House." 86 In August 1864, John Mullaly was arrested and imprisoned on charges of willfully counseling "Seymour and other persons to resist" the draft established by law. ${ }^{87}$

To many Irish Americans, the Civil War was seen as a costly and treacherous war with no end in sight, which greatly influenced who they supported in the 1864 presidential election. The Irish of the North overwhelmingly identified with the Democrats due to their racial beliefs and the party's assistance to the Irish people in places like New York City. Therefore, many Irish Americans had little interest in reelecting Abraham Lincoln and the Republican Party. Their beloved former army commander and Democratic nominee, George B. McClellan, seemed like the natural choice for Irish Americans. Even so, McClellan worked diligently to secure the Irish vote. In 1863, he helped to organize and raise funds for the relief of the poor of Ireland. This strategy worked overwhelmingly for McClellan. The New York Irish American explained that,

Mr. Lincoln's administration has endeavored to substitute a government of force for that of right, and to replace the voluntary obedience of love by the subjection of fear. These are the first of the insidious approaches by which despotism ever seeks to win its way to absolute authority. If the American people, in this election, through default or weakness, entrust the management of their affairs to $\mathrm{Mr}$. Lincoln, they place their liberties at the mercy of a party who have proved themselves already faithless to every trust reposed in them, and who can from their past policy, give no guaranty, that the immunity offered by a new term of office will not induce them to push their invasion of the rights of the people to the utmost extremes.

\footnotetext{
${ }^{85}$ Metropolitan Record and New York Vindicator, June 4, 1864.

${ }^{86}$ Metropolitan Record and New York Vindicator, June 18, 1864.

${ }^{87}$ Joseph George Jr., "“A Catholic Family Newspaper' Views the Lincoln Administration: John Nullaly’s

Copperhead Weekly," Civil War History 24, No. 2 (June 1978): 125.
} 
However, a vote for McClellan would ensure "the restoration of peace and Union, and the reestablishment of that prosperity for the development of which the country is so admirably calculated by nature, and of which she can only be deprived by the perversity and malignant passions of unprincipled men." $" 88$

The majority of the northern Irish-American communities were loyal Democrats because the party had accepted them in the face of widespread nativism in the pre-war years. This identity was incredibly important to Irish soldiers as the election came closer. A member of the Irish Brigade wrote home to his mother expressing his support for McClellan stating, "I have no particular news only about the Election which will be a hard contest. I hope Little Mac will be the man. ${ }^{\prime 89}$ A letter published in the Irish American written by Captain Thomas Norris of the 170th New York Infantry, part of Corcoran's Irish Legion, is exemplary of the Irish views towards the election. In his letter to an unnamed sergeant, Norris sarcastically writes, "You compliment me highly, indeed, when you say- 'I suppose that all of you (officers) will vote for Old Abe and the niggers.' I think I taught you to be more respectful to your superior officers." Although he explained, like a "true Democrat," how he would support Lincoln if he were reelected, Norris said, "I hope the country will have a man that will say to the whipped party [Republicans]- 'Arise and don't whine over your bruises. It's all your fault. You have done wrong against your father's house (the Government and the Constitution), and got the worst of it." ${ }^{\prime 90}$ This letter expressed the belief of many Irish Americans who now felt as though the war was fought for the personal benefit of the Republicans and their emancipation campaign. Irish

\footnotetext{
${ }^{88}$ Irish American, November 5, 1864.

${ }^{89}$ Civil War Widows' Pension of Charles Trainor, 69th New York Infantry, accessed at fold3.com, August 14, 2019.

${ }^{90}$ Irish American, October 22, 1864.
} 
private James O'Neill disliked Lincoln because he felt as though he would prolong the war "until Slavery is abolished..."91

Nativism towards Irish Americans continued throughout 1864, and was popularly expressed during the presidential race. Days before the election, Harper's Weekly ran a cartoon titled "Peace' Democracy on the Rampage" (Figure 6). In this image, McClellan supporters are depicted as thieves, rioters, and murderers. The central figure of the image is an Irish-American Catholic with ape-like features. The Irishman is standing over the bodies of an African-American woman and her child with a club in one hand and the end of a noose in the other. The scene in the cartoon is no doubt intentionally reminiscent of the New York City draft riots that took place over a year earlier. Despite the fact that more than 150,000 Irish Americans served in the Union Army and Navy, they were still depicted as irresponsible and ignorant citizens. This and other cartoons were popular among native-born Americans and helped spread the idea that the Irish were dangerous individuals. ${ }^{92}$ New York diarist and Republican George Templeton Strong shared these nativist views, arguing that the problems in the country were due to the, "PeaceDemocrats, McClellan-maniacs, mere traders and capitalists, and the brutal herd of ignorant Celts and profligate bullies and gamblers..." Closer to the election, Strong described McClellan's Democratic supporters as "hordes of Celts and rebel sympathizers..." who were the "liquor dealers, roughs, and brutal Irishy of the city..."93

Although supporting the Democratic Party was important for most Irish Americans, Republicans and native-born Americans failed to understand why the ethnic group largely identified with the party and believed they were duped into backing McClellan. Overwhelming

\footnotetext{
${ }^{91}$ James O’Neill, 4th Delaware Infantry, Petersburg, Virginia, Letter to Mother and Father, October 12, 1864, Delaware Folder, Five Forks Unit, Petersburg National Battlefield Collection.

${ }^{92}$ Harper's Weekly, November 5, 1864.

${ }^{93}$ Strong, Diary of the Civil War, 452, 509, 511-512.
} 
loyalty to the Democrats was a way for Irish Americans, particularly in cities like New York, to promote their own interests in the country. Democrats proved their loyalty to the New York City's Irish-American community over the last several years. During the war, New York's city council set aside six million dollars to aid destitute families of Irish volunteers and appropriated other money to assist the city's poor. ${ }^{94}$ For reasons like this, Irish Americans during this time were the "most strongly and consistently Democratic of the newer immigrant groups." 95 Unfortunately, this tied them to the party that was associated with secession, slavery, and the Copperhead movement.

Irish Americans in the Union Army held the same views about the upcoming election and planned to cast their vote for McClellan, however evidence exists that Abraham Lincoln and the Republican Party restricted their voting and speech rights. ${ }^{96}$ Historian Jonathan White has shown that Democratic soldiers "complained that it was difficult to vote the Democratic ticket in the field." ${ }^{97}$ This was evident in a letter written by an Irish soldier in the 69th New York Infantry. From his hospital bed in Washington D.C., Patrick McCaffrey wrote, "there is some getting home on furlough But I here they must promise to vote for Lincoln before the[y] leave here

\footnotetext{
${ }^{94}$ Spann, "Union Green: The Irish Community and the Civil War," 206-207.

${ }^{95}$ Paul Kleppner, The Third Electoral System, 1853-1892: Parties, Voters, and Political Cultures (Chapel Hill: The University of North Carolina Press, 1979), 61.

${ }^{96}$ Multiple historians have attempted to explain why the soldier's vote went to Lincoln over McClellan and have claimed that they became Republicans during their time in the Union Army. James M. McPherson has claimed in multiple books that by 1864, Union soldiers had converted to Republicanism. Historian Chandra Manning has gone even further than McPherson by arguing that a large number of Union soldiers supported Emancipation as early as 1861. To support her argument, Manning points to the overwhelming amount of soldiers who voted to reelect Lincoln in 1864. Neither author considered the possibility of voter intimidation in the Union Army to explain the high percentage of soldier votes for Lincoln. See James M. McPherson, For Cause and Comrades: Why Men Fought in the Civil War (New York: Oxford University Press, 1997); James M. McPherson, Ordeal by Fire: The Civil War and Reconstruction, 3rd ed. (New York: McGraw-Hill, 2001); and Chandra Manning, What This Cruel War Was Over: Soldiers, Slavery, and the Civil War (New York: Alfred A. Knopf, 2007). For the best look on the 1864 Presidential Election and the actions of the Republican Party to reelect Abraham Lincoln, see Jonathan W. White, Emancipation, The Union Army, and the Reelection of Abraham Lincoln (Baton Rouge: Louisiana State University Press, 2014).

${ }^{97}$ White, Emancipation, The Union Army, and the Reelection of Abraham Lincoln, 117.
} 
which I wont do..." ${ }^{98}$ Other records show Democratic soldiers were court martialed for distributing Democratic campaign material in camp, Democratic newspapers were restricted to soldiers, and only Republican ballots were distributed to some soldiers. ${ }^{99}$ Considering all this, an overwhelming seventy-eight percent of the soldier's vote went to Lincoln with the other twentytwo percent going to McClellan. It is difficult to determine how the Irish soldiers voted, but most evidence suggests that the majority chose McClellan over Lincoln. ${ }^{100}$

New York's Irish vote was not representative of how the rest of the country voted in the 1864 Presidential election. Because the Irish of New York identified with the Democratic Party, large numbers cast their vote for George McClellan. In some areas of New York, including the heavily Irish Sixth Ward, McClellan received ninety-percent of the vote. New York City as a whole went to McClellan with more than a two-to-one majority. ${ }^{101}$ Despite this and other pockets of Democratic support, Abraham Lincoln received fifty-three percent of the civilian vote while McClellan gained forty-seven percent. ${ }^{102}$ Even with the popular vote being so close, the 1864 Presidential Election was a great victory for the Republican Party. McClellan took only three states - New Jersey, Kentucky, and Delaware — and lost the Electoral College with the vote of 212 to 21 . Democrats lost control of critical states that seemed so secure in 1862. Even New York’s Democratic Governor, Horatio Seymour found himself out of power. ${ }^{103}$

Democratic defeat was a defeat for the Irish and caused Republicans to oppose the ethnic group for many years later. The feeling of betrayal among native-born Americans towards the

\footnotetext{
${ }^{98}$ Civil War Widows' Pension of Patrick McCaffrey, 69th New York Infantry, accessed at fold3.com, August 14, 2019.

${ }^{99}$ White, Emancipation, The Union Army, and the Reelection of Abraham Lincoln, 117-119.

100 Oscar Osburn Winther, "The Soldier Vote in the Election of 1864," New York History 25, no. 4 (October, 1944): 458.

101 Spann, "Union Green: The Irish Community and the Civil War," 208.

102 Winther, "The Soldier Vote in the Election of 1864," 458.

103 John C. Waugh, Reelecting Lincoln: The Battle for the 1864 Presidency (New York: Crown Publishers, Inc., 1997), 354.
} 
Irish seemed to culminate after President Lincoln's assassination on April 14, 1865. Despite the fact that Irish newspapers throughout the United States mourned the loss of the President, some native-born Americans questioned the sincerity of their grief. New York diarist George

Templeton Strong reported that dozens of New York families fired their "Celtic handmaidens...for some talk of rejoicing at Abe Lincoln's death.” Similar action was taken against Irish waiters at the Gramercy Park House for their "blind, foolish, Celtic talk approving Lincoln's murder."104 This image of disloyalty followed the Irish for years to come.

In the years that followed the surrender at Appomattox, native-born Americans in New York were quick to forget the sacrifices of Irish Americans and instead pointed to the large number of Irish Catholics who strongly opposed the war and emancipation. Anglo Americans linked these actions to Irish ethnic identity. While New York Irish Americans preserved their ethnic pride by showing their support and gratitude to Irish soldiers in community celebrations, it would be years before Irish veterans began to remind the country of their loyalty to the Union and America. As anti-Irish prejudice continued into the postwar period, significant numbers of Irish Americans wondered if their choice to fight was worth the loss. Despite the fact that over 150,000 Irish served in the Union, much of the native-born population only focused on the draft riots, outspoken criticism towards the Republican Party, and the ethnic group's hatred towards African-American freedom. In 1870, a British traveler confirmed the disillusionment among the Irish in New York when he wrote, "In no part of the world are the virtues of the Irish so little appreciated...[and] in no part is the name of Irishman a greater obstacle to a man's success" than in the United States. ${ }^{105}$ Even when faced with nativist attacks, Irish Americans in New York

\footnotetext{
${ }^{104}$ Strong, Diary of the Civil War, 586.

105 John White, Sketches from America (London: Sampson, Low, Son, and Marston, 1870), 353.
} 
stood united behind their ethnic identity to gain new opportunities and autonomy in the postwar years.

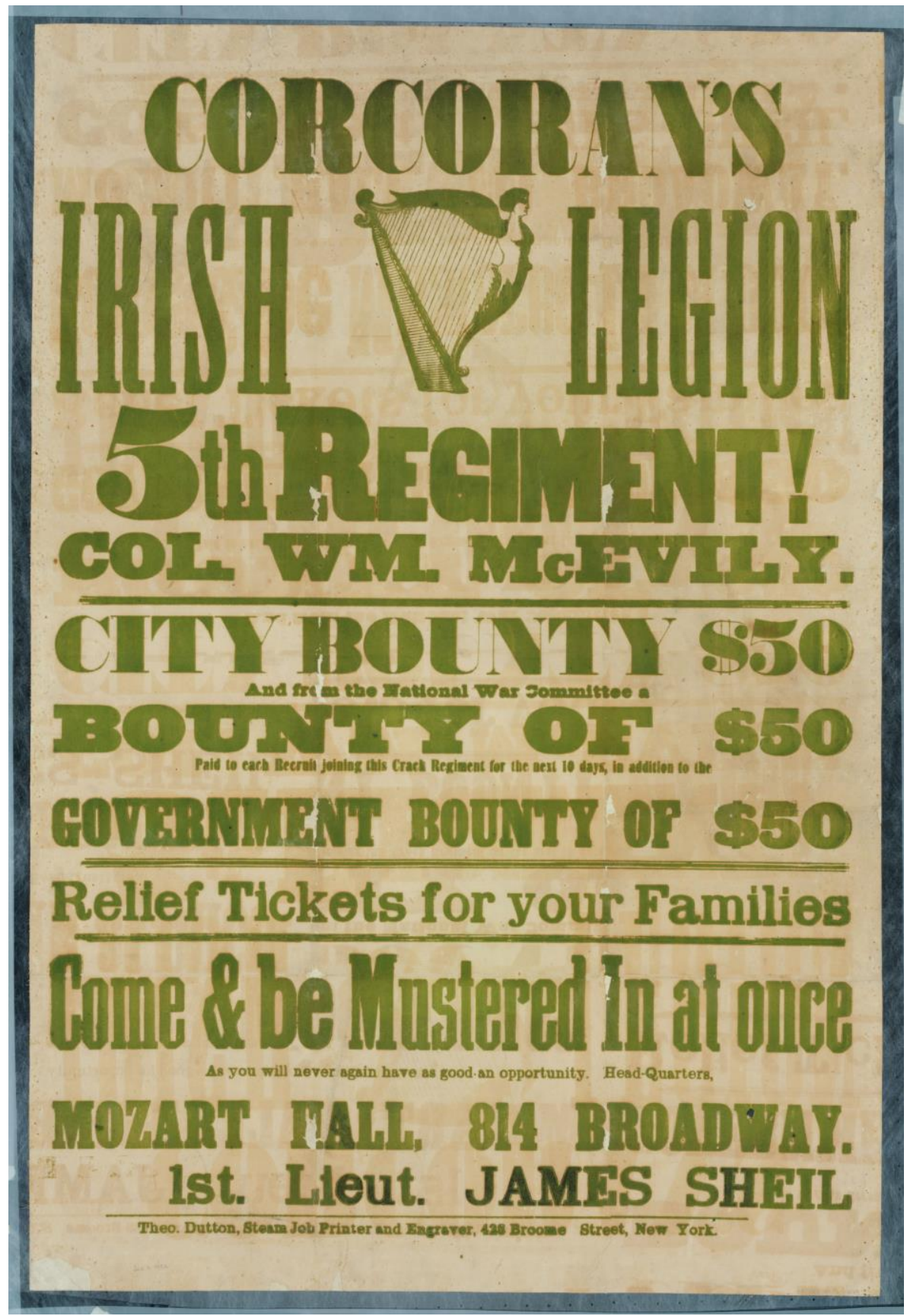

Figure 5: Corcoran's Irish Legion Recruitment Poster (New York Historical Society Museum \& Library) 


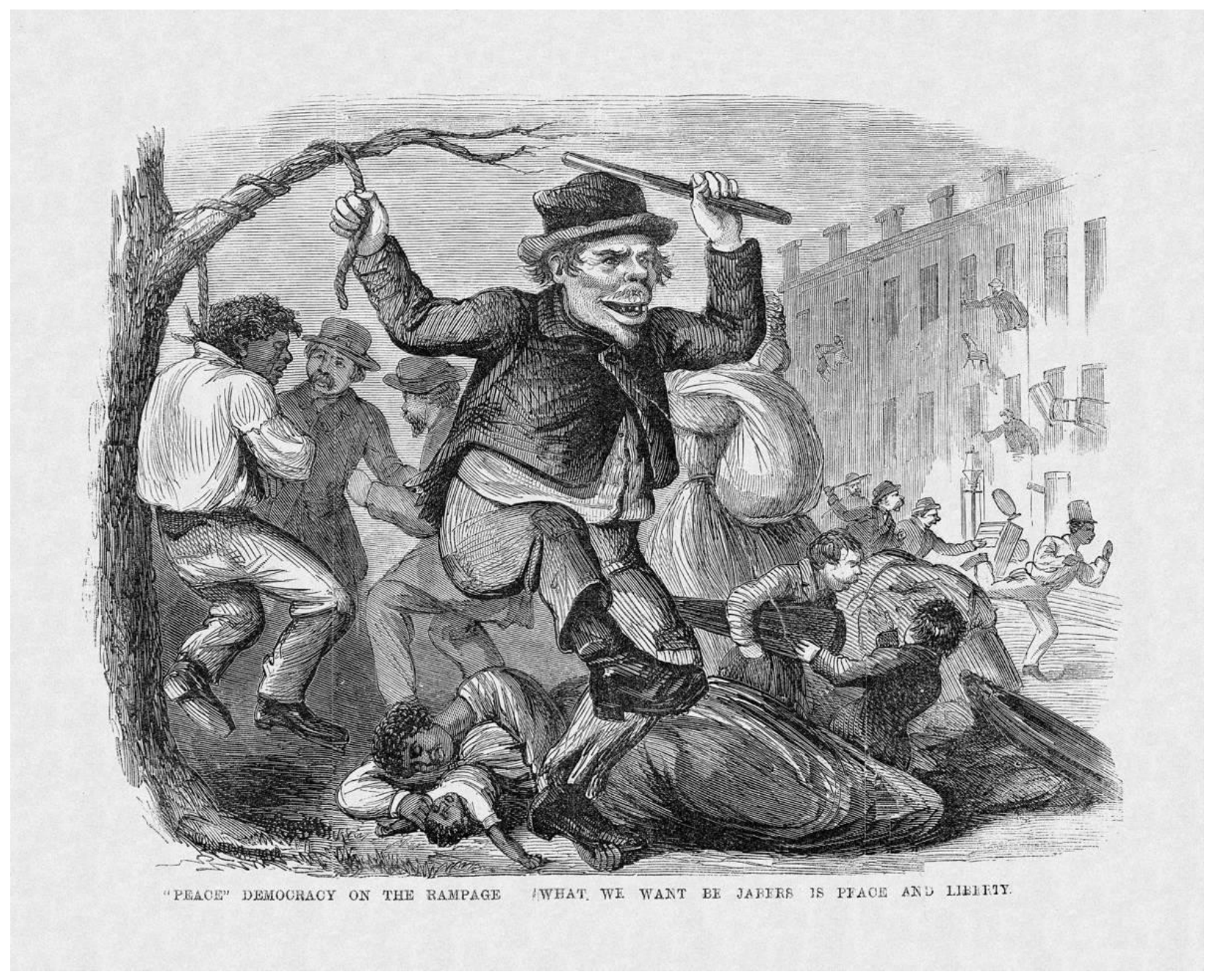

Figure 6: “'Peace' Democracy on the Rampage," Harper's Weekly, November 5, 1864. 


\section{Conclusion}

Nativist prejudice continued to plague Irish Americans in the years that followed the American Civil War. Even amidst this hatred, the New York Irish continued to unite behind their ethnic identity through religious, military, and cultural celebrations. Even as they alienated large segments of the Anglo-American population, Irish Americans in New York began to see the power they could wield as a united force. The Irish in the postwar period retained strong local connections that began in the antebellum period, continued throughout the Civil War, and ultimately developed into a powerful sense of autonomy. Although their ethnic identity changed over time, certain aspects remained vital to how they understood themselves as an ethnic group in America. While this led to criticism, it also provided new opportunities for the Irish in the United States and allowed the ethnic community to carve out a place in postwar America. Increasing numbers of immigrants from the Emerald Isle in the 1860s and 1870s also assisted the ethnic group in New York to secure political power. By the postwar period, Irish numbers were so impressive and their practice of voting as a bloc was so strong, that Democratic politicians came to depend on Irish Catholic support. This did not happen instantly, however, as the Irish continued to face economic and social problems. Even so, this reality left Irish Americans in New York more determined to unite behind their ethnic identity in an effort to secure rights that benefited them. Although this struggle took decades, their experiences in the Civil War reinforced and strengthened their ethnic bonds, which provided the Irish an opportunity to carve out a unique place within American culture.

While all soldiers and their communities memorialized their service in the Civil War in different ways, the New York Irish tended to reflect on their wartime sacrifices differently than Irish-American populations elsewhere in the North. Many members of the Irish Brigade, 
including David Power Conyngham, William Corby, and St. Clair Mulholland, published postwar accounts of their service in the Civil War and worked to shape the way Irish-American service to the Union was remembered. Conyngham wrote The Irish Brigade and Its Campaigns, "with the sole desire of helping to rescue from obscurity the glorious military record we have earned in America." ${ }^{1}$ Other members of the brigade similarly noted the sacrifice and bravery of Irish veterans while ignoring the role members of their ethnic group played in the copperhead movement and events like the draft riots. As historian Ryan Keating has shown, Irish veterans from Wisconsin, Connecticut, and Illinois remained largely obscure in these efforts. ${ }^{2}$ While Irish veterans outside of New York remained proud of their service to the Union, most New York Irish chose to place more emphasis on their Civil War experiences, in an attempt to secure economic, social, religious, and political success within their state. Unlike Irish communities in Wisconsin, Illinois, and Connecticut, the New York Irish retained their distinct Irish enclaves in the postwar years. While Irish Americans outside of New York tended to express an array of fluid identities in the postwar years, the New York Irish continued to demonstrate their ethnic identity very publicly through military, cultural, and religious endeavors. This does not mean that the New York Irish were more Irish than their ethnic neighbors elsewhere in the North, however it does show that their experiences in the Civil War did not change their willingness to express their ethnic pride and unity.

The actions of Irish nationalists in the postwar years reveal that Irish Americans were determined to act on their own interests even if native-born Americans did not accept their beliefs. Fenians, a brotherhood of Irish nationalists in America who had ties to the Irish Republican Brotherhood in Ireland, planned to attack and hold hostage, several British North

\footnotetext{
${ }^{1}$ David Power Conyngham, The Irish Brigade and its Campaigns (Glasgow: R \& T Washbourne, 1866), 10.

${ }^{2}$ Ryan W. Keating, Shades of Green: Irish Regiments, American Soldiers, and Local Communities in the Civil War Era (New York: Fordham University Press, 2017), 204-212.
} 
American possessions in Canada in exchange for Ireland's freedom. New York City, where the Fenian Brotherhood began, was home to the most members of the organization. By the end of the Civil War, there were a reported forty-seven Fenian circles in New York alone, and the group's leaders hoped to use the training that many of these Irishmen gained throughout their service in the Civil War to secure Ireland's freedom. ${ }^{3}$ Surprisingly, the group received support from some native-born Americans. However, this may have been because Americans were angered over Britain's sympathy for the Confederacy during the Civil War. The New York Times, which often published nativist articles, stated "Weak as this Fenian movement is, we say to-day, unhesitatingly, that it needs from America but the same support which the Southern rebellion received from England to give it force that would rock the British kingdom to its foundations." ${ }^{4}$

Despite this perceived support, the Fenians did not receive any direct backing by the United States government. As the Irish nationalists conducted a series of raids into Quebec in 1866 and again in 1870 and 1871 with strikes into Quebec, New Brunswick, and Manitoba, they discovered the limits of American support. On almost every raid, the Fenians faced varying degrees of United States interference. In 1871, President Ulysses S. Grant used the Fenian invasions to assist in a political negation with the British government. Because the Irish invasions would hinder the negotiations, the United States government confiscated Fenian weapons, refused to negotiate the release of Irishmen held in Canadian prisons, and prosecuted Americans who aided the Fenians. This greatly impacted native-born Americans opinions of the Fenians and caused the little support the group had to dwindle. ${ }^{5}$ Even so, the Fenian raids

\footnotetext{
${ }^{3}$ Proceedings of the Second National Congress of the Fenian Brotherhood, Held in Cincinnati, Ohio, January 1865 (Philadelphia: J. Gibbons, 1865), 17-18.

${ }^{4}$ New York Times, September 28, 1865.

${ }^{5}$ See Brian Jenkins, Fenians and Anglo-American Relations during Reconstruction (Ithaca, NY: Cornell University Press, 1969); Christopher Klein, When the Irish Invaded Canada: The Incredible True Story of the Civil War Veterans Who Fought for Ireland's Freedom (New York: Anchor Books, 2019); and Hereward Senior, The Last Invasion of Canada: The Fenian Raids, 1866-1870 (Toronto: Dundurn Press, 1991).
} 
demonstrate how Irish Americans were willing to advance their ethnic interests at the expanse of native-born approval in the postwar years. Therefore, Irish Americans relied on their power as an ethnic group to advance their own interests in America and Ireland, rather than worry about assistance from their fellow Americans.

As with the Fenian raids, many Irish Americans were unwilling to renounce their Catholic faith and accept the dominant Protestant cultural traditions. Irish Americans continued to emphasize their self-reliance to achieve their interests in America by maintaining their own ethnic and religious traditions, even at the expense of native-born support. Postwar nativism provided a motivating force for the creation of a unified Irish community. With the 1870 and 1871 Orange Riots, which involved violence between New York Irish Protestants and Catholics, the majority of native-born Americans supported the former. ${ }^{6}$ Even though many Irish Americans did not participate in the violence, sweeping anti-Irish sentiment appeared in the leading newspaper like the New York Times, Herald, Tribune, and Harper's Weekly. IrishAmerican newspapers like the Irish World, Irish American, and Irish Citizen pointed to IrishAmerican loyalty to the Union during the Civil War to defend their ethnicity. During this nativist sentiment, Irish Americans worked to create a clear identity for themselves in New York. The St. Patrick's Day ceremony and parade provided a key way for these ethnic ties to manifest publicly. The continuation of the parade in New York City allowed Irish Americans to reinforce their sense of belonging and helped the ethnic group maintain power and unity within the city's Irish community. The St. Patrick's Day celebrations demonstrated the growing strength and influence of the Irish in New York. The spectacles were not only a way for Irish Americans to proclaim

\footnotetext{
${ }^{6}$ For the best look at the New York City Orange Riots, see Michael A. Gordon, The Orange Riots: Irish Political Violence in New York City, 1870-1871 (New York: Cornell University Press, 1993).
} 
their ethnic and religious unity, but also to present the potential power and strength of a consolidated Irish vote.

Despite the rising Irish-American population in New York, the ethnic group was significantly under-represented in the city and state government, which hindered their ability to promote their ethnic interests. As the New York newspaper the Irish World argued, "The great body of the Democratic Party has consisted of Irish-American citizens, but the heads put upon that body have been, in nine cases out of ten, Anglo-Americans." The paper continued, explaining, "In their caucuses our element was studiously ignored, and our claims, if brought forward, were dismissed as impertinent." In places like New York City and Brooklyn, "little knots of Irish politicians, hangers on of the City Halls, might be seen; and the crumbs brushed from the tables of the great were thought to be compensation enough for them and recognition enough for us."7 In fact, Irish representation in city politics actually declined even as the Irish population increased. Between 1844 and 1884, the Irish population in New York City rose from nearly twenty to forty percent. However, they only held fourteen percent of political positions under the city's Democratic leadership, while native-born Democrats dominated the city's political offices. This statistic left Irish Americans determined to publicly challenge New York politics so that their interests would be better represented by the party they overwhelmingly identified with. $^{8}$

Unlike Irish veterans in Wisconsin or Connecticut, many New York Irish Americans chose to form their own veterans' organizations rather than join the more popular groups such as the Grand Army of the Republic (G.A.R.). ${ }^{9}$ Some Irish veterans joined groups like the G.A.R.,

\footnotetext{
${ }^{7}$ Irish World, August 3, 1872.

${ }^{8}$ Lawrence J. McCaffrey, The Irish Catholic Diaspora in America (Washington, D.C.: Catholic University of America Press, 1997), 223.

${ }^{9}$ Keating, Shades of Green, 208-209.
} 
however most tended to join posts with members that held similar ethnic and religious backgrounds. Even so, Catholic immigrants were significantly underrepresented in the Grand Army of the Republic. One of the major factors that contributed to this was due to the beliefs of the Catholic Church. Catholics discouraged its members from joining fraternal organizations that required its members to take oaths and participate in secret rituals. ${ }^{10}$ Furthermore, the majority of the organization's celebrations, such as Memorial Day services, were held in Protestant Churches, which would have added to the lack of Irish Catholic members. Rather than join the G.A.R., Irish Americans who served in New York Regiments formed the Irish Brigade Association in 1869. The association was founded to collect "historical, scientific, and literary material, and mementoes having connection with the services of the Irish Brigade during the war" and honor the men who served in the Brigade. ${ }^{11}$ The association became a well-respected group among the New York Irish-American community and allowed the ethnic group to remember the service of their friends and family.

The actions and sacrifice of Irish-American soldiers during the Civil War were continuously overshadowed and forgotten by military officials in the postwar years. Articles in the Army and Navy Journal contained nativism towards immigrant soldiers. The journal reported that the state of New York "is at all times ready to receive acquisitions to its National Guard force, and has never made nationality a drawback." The editor went on to specify, however, "when a man enters the State or United States service and wears the uniform of soldiery, he throws aside his allegiance to his native land, and all the issues appertaining thereto must die out." ${ }^{12}$ Comments such as these eventually led to new recruiting policies in 1894, when Congress

\footnotetext{
${ }^{10}$ Stuart Charles McConnell, Glorious Contentment: The Grand Army of the Republic, 1865-1900 (Chapel Hill: University of North Carolina Press, 1992), 79-80.

${ }^{11}$ New York Herald, January 30, 1869.

12 The Army and Navy Journal, August 5, 1871.
} 
passed a law restricting first enlistments to United States citizens or individuals who legally stated their intention to become a citizen. Likewise, all new soldiers had to prove their ability to speak, read, and write English. This legislation led to a drastic decline in foreign-born soldiers. By 1896, the number of immigrants dropped from more than one third to around one fourth of all new soldiers. ${ }^{13}$ This legal change caused Irish Americans, particularly those of large cities, to believe immigrant service in the Civil War went unnoticed by military personnel.

Irish communities in New York continued to suffer economic and social problems in the postwar years. Poverty forced the ethnic group to live in overcrowded areas such as the largely Irish Tenth Ward, where there were 276,000 people per square mile. Because these Irish residents were unable to leave their homes and jobs for the countryside due to their economic situation, diseases like smallpox and cholera spread rapidly. In the years following the Civil War, Irish-American men still earned an average of only \$300 per year, while \$700 was considered to be the average subsistence salary of the time. Postwar Irish-born Americans occupied fifty percent of the worst paying jobs in New York City, even though they comprised only twenty percent of the population. As late as 1880, twenty percent of New York Irish Americans were still working as unskilled laborers, whereas only four percent of native-born Americans held such positions. These conditions contributed to the fact that five Irish were arrested to every one German in New York City during the 1870s. This also led many native-born Americans to believe the problem in their city was not related to immigrants but rather the Irish in particular.

\footnotetext{
${ }^{13}$ Edward M. Coffman, The Old Army: A Portrait of the American Army in Peacetime, 1784-1898 (New York: Oxford University Press, 1986), 330-331.
} 
Even though many Irishmen joined the Union Army for economic reasons, their Civil War service seemed to have little effect on their postwar condition in New York. ${ }^{14}$

Even with these problems, Irish Americans in New York used their increasing population to secure political power for their ethnic group. By the late nineteenth century, Irishmen in New York were presented with new opportunities to gradually increase their political power. One visitor to the city recalled that, "New York is peopled by the Irish to such an extent that the government of the locality depends chiefly upon their vote, and so far as I was able to judge, the Irish in New York are by far the most important portion of the foreign element there. The persons highest in office are Irish; many of the judges, the leading barristers, and the merchants of rank are Irish..." ${ }^{\prime 15}$ As the increasingly Irish-dominated New York political machine Tammany Hall gained more power and influence, newspapers began to portray the group alongside images of the Ku Klux Klan and Confederate veterans rather than acknowledge the large Irish population that supported the Union. During the 1872 presidential election, Harpers Weekly published a political cartoon titled “A 'Liberal' Surrender-Any Thing to Beat Grant.” In the cartoon, Horace Greely and Carl Schurz stand behind the battlements surrendering to the Democratic Party. The cartoonist chose the Ku Klux Klan, Confederate veterans, Copperheads, and the Irish-influenced Tammany Hall to represent the Democratic Party (Figure 7). Even though over 150,000 Irish Americans served in the Union Army during the Civil War, the ethnic group was portrayed as the attacking force against American democracy. Though insulting, disloyal characterizations like this demonstrate the growing power Irish Americans held in New York's postwar politics. By the late nineteenth century, Irishmen in New York City and Albany

\footnotetext{
${ }^{14}$ Hasia R. Diner, "Overview: 'The Most Irish City in the Union,' The Era of the Great Migration, 1844-1877," in The New York Irish, ed. Ronald H. Bayor and Timothy J. Meagher (Baltimore, MD: Johns Hopkins University Press, 1996), 97-99; McCaffrey, "Forgoing Forward and Looking Back," 216-218.

${ }^{15}$ Arthur Blennerhassett Leech, Irish Riflemen in America (London: Edward Stanford, 1875), 43.
} 
began to fill seats in the State Assembly, rise to the office of mayor, and even secure elections to the United States House of Representatives. The gradually increasing political power was due to Irish-American organization and activism that led to Irish American dominance of New York City politics until the early twentieth century. ${ }^{16}$

Beyond political issues, Irish Americans in New York made religious and cultural efforts to enhance and unite behind their ethnic identity in the postwar years. In the decades that followed the end of the Civil War, the Catholic Church constructed thousands of cathedrals, churches, rectories, convents, colleges, and seminaries. In 1874, an Irishmen in New York rejoiced over the fact that "we can mind our [religious] duty as well here as we can do in Ireland if it is not our own fault." 17 Throughout this period Irish Catholics worked to secure their religious rights in the midst of continued anti-Catholic hatred. Similarly, in an effort to preserve Irish culture in the United States, Michael J. Logan, an immigrant from Galway and founder of the Brooklyn Philo-Celtic Society, began publishing An Gaodhal in 1881. The journal informed Irish Americans of Irish art and music and encouraged them to read and study Irish literature and history. An Gaodhal not only pushed to teach and preserve the Gaelic language in America, by offering Gaelic lessons in every issue, but it also strove to elevate the social standing of the Irish in the United States. ${ }^{18}$ New York Irish Americans also made a conscious effort to insert themselves into American military memory. Postwar memoirs of Irish-American veterans emerged, with most ignoring the role of the ethnic group in the draft riots and the anti-war movement. Furthermore, to help promote the role of Irish-American service in the Union war effort and respond against the anti-Irish attacks, the American Irish Historical Society in New

\footnotetext{
${ }^{16}$ Kevin Kenny, The American Irish: A History (New York: Longman, 2000).

${ }^{17}$ Quoted in Kerby A. Miller, Emigrants and Exiles: Ireland and the Irish Exodus to North America (New York: Oxford University Press, 1985), 526.

${ }^{18}$ Una Ni Bhromeil, "The Gaelic Movement in the United States, 1870-1915," New Hibernia Review 5, no. 3

(Autumn 2001): 88-89.
} 
York City was established in $1897 .{ }^{19}$ These efforts helped Irish Americans in New York to unite behind their shared diasporic identity that was strengthened and reinforced through their experience in the Civil War.

It is crucial to understand how service in the Civil War strengthened ethnic consciousness for New York Irish Americans. The importance of ethnic identity only grew stronger and developed as their interests as Irish Americans came into conflict with the Union war effort. Even amid nativism in the post-war years, the New York Irish became a powerful force in American politics and religion. As a poor immigrant group in a weakened minority party, the Irish faced a long and difficult struggle, but the ethnic ties that were tested and ultimately strengthened through service in the Civil War helped the Irish confront the overwhelming Protestant nation and become a powerful voting bloc within American democracy. Discrimination against the Irish continued throughout the nineteenth century because of how this emerging power frightened native-born Americans. Even amid this prejudice, Irish Americans in New York wielded their unified loyalty to enact political changes that benefited their ethnic communities. The ethic group pushed for greater rights while building their ethnic culture. Although the Irish would become American on their own time, they purposefully chose to retain parts of their Irish ethnic identity, which led to the emergence of cultural diversity in the United States that countered the Anglo-American Protestantism. Through the recognition of Irish multiculturalism in America, the sacrifice and struggle of the Irish Brigade and their accompanying communities in the American Civil War can really be appreciated.

\footnotetext{
${ }^{19}$ Bluford Adams, "New Ireland: The Place of Immigrants in American Regionalism," Journal of American Ethnic History 24, no. 2 (Winter 2005): 7.
} 


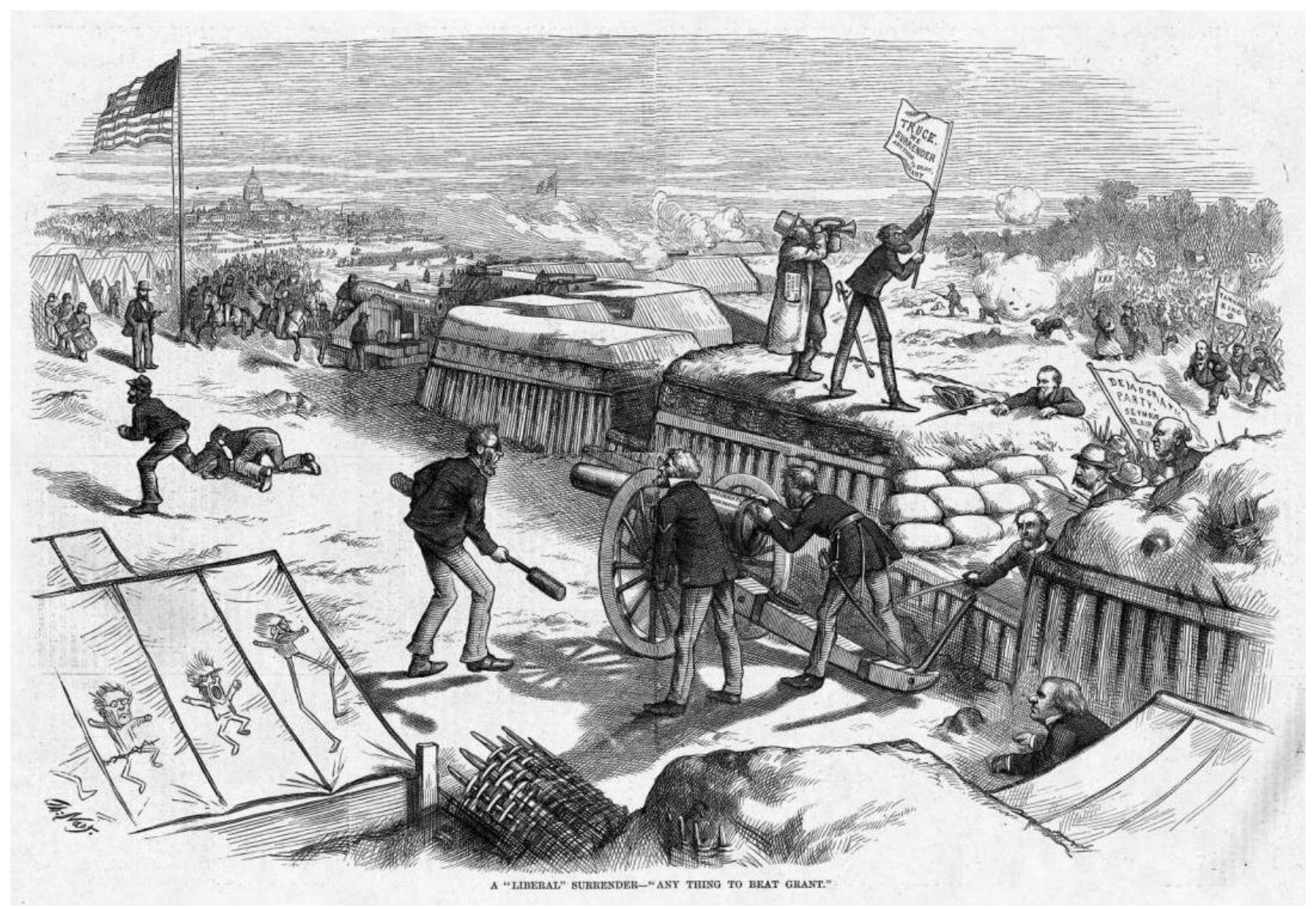

Figure 7: “A 'Liberal' Surrender-Any Thing to Beat Grant,” Harper's Weekly, May 11, 1872. 


\section{Appendix A:}

\section{"One Cracker A Day"}

You friends of the soldiers I pray lend an ear

A sad and a true story I will let you hear

I'll sing you a song about our rations and pay

And how we subsist on a cracker a day.

To get such cruel treatment indeed it is a shame

But the administration of course is to blame

They've neglected to give us our rations or pay

And compelled us to live on one cracker a day.

Many of us long in the service has been

And many a battle and skirmish have seen

But it's sweeter to fight or to die in the fray

Than to be compelled to subsist on one cracker a day.

Sometime we get more but oftener it's less

But na'ry time do we get a full mess

On an average all through 'tis the truth that I say

All a soldier receives is a cracker a day.

And many a poor soldier through hunger must go

Without shoe or stocking in rain, frost, and snow

And many a poor soldier is heartbroken today

From sickness, exposure and a cracker a day.

We enlisted without a thought that deceived we would be And sent down to Dixie to set niggers free

We enlisted to fight for a more glorious cause

In defense of our flag, our union, and laws.

Old Abe's proclamation we soldiers do abhor

It will do us no good but will prolong the war And while this war lasts, it is true what I say

Each soldier must live on a cracker a day.

All ye shoddy patriots who hang around home

Who are howling for blood but they won't risk their own

For them the poor soldier from home far away

Half naked, half starved on a cracker a day

All the Greeleys and Chanlers will meet their downfall 
The abolition bloodhounds contractors and all

For a speech or a vote they get three years pay

Of a soldier who lives on a cracker a day.

Whilst the soldiers are starving the negro grows fat

They get their full rations are clothed and all that

The Abolitionists treat them in a different way

From the soldiers who get but a cracker a day.

Though the soldier is lame from the wound and the scar

They must walk while the niggers ride free in the car

The cars are well laden with those sooty scamps

Whilst the hero of Shiloh and Donalson tramps. 


\section{Appendix B:}

"Fight for the Nigger"

I calculate of darkies we soon shall have our fill, With Abe's Proclamation and the Nigger Army Bill. Who would not be a soldier, the Union for to fight, Now Abe has made the Nigger the equal of the White?

Each soldier must be loyal and his officers obey, Tho' he lives on mouldy biscuits and fights without his pay; If his wife at home is starving he must not be discontent, Tho' he waits six months for "greenbacks," at forty-five per cent.

Moreover if you're drafted, do not refuse to go, You're equal to the Nigger and can make as good a show; When you are in a battle, to the Union be true, But don't forget the Nigger is as good a man as you.

When ordered into battle, go in without delay;

Tho' slaughtered just like cattle, 'tis your duty to obey, For when old Jeff is captured, pr' aps paid up you'll be, If you ain't don't mind the money, but set the Nigger free.

Three cheers for honest Abram, he'll be a great man yet; Tho' he's loaded us with taxes and burdened us with debt, He often told us little jokes, while pocketing our pelf, And his last has made the Nigger the equal of himself.

Guard well the Constitution, the Government and Laws; To every act of Congress don't forget to give applause. And when you meet the rebels, be sure to drive them back, Tho' you do enslave the white man you must liberate the black. 


\section{Bibliography}

\section{Primary Sources:}

$\underline{\text { Archival Material: }}$

Antietam National Battlefield Archive, Sharpsburg, Maryland 29th Massachusetts Infantry Vertical File 69th Pennsylvania Infantry Vertical File

Daughters of Charity Provincial Archives, Emmitsburg, Maryland Notes of the Sisters' Service in Military Hospitals 1861-1865 Sisters of Charity who Nursed During the Civil War.

Fredericksburg \& Spotsylvania National Military Park Archive, Fredericksburg, Virginia James E. Decker Letters John Dwyer George S. Grove Letters William Smith Letters Will, 27th Connecticut Infantry Letters

National Archives and Records Administration, Washington, D.C. Sixty-Ninth New York Infantry Regimental Descriptive, Letter, Order and Miscellaneous Book, Record Group 94, Records of the Adjutant General's Office.

Petersburg National Battlefield Collection, Petersburg, Virginia James O’Neill, Delaware Folder

Books:

Bowen, James L. Massachusetts in the Civil War, 1861-1865. Springfield, MA: Clark W. Bryan \& Company, 1889.

Cavanagh, Michael. Memoirs of General Thomas Francis Meagher, Comprising the Leading Events of His Career Chronologically Arranged, with Selections from his Speeches, Lectures, and Miscellaneous Writings, Including Personal Reminiscences. Worcester, MA: The Messenger Press, 1892.

Conyngham, David Power. The Irish Brigade and its Campaigns. Glasgow: R \& T Washbourne, 1866.

Coolidge, Richard H. Statistical Report on the Sickness and Mortality in the Army of the United States, Compiled from the Records of the Surgeon General's Office, Embracing a Period of Sixteen Years, from January 1839 to January 1855. Washington, D.C.: A.O.P. Nicholson, 1856. 
Corby, William. Memoirs of Chaplain Life: Three Years with the Irish Brigade in the Army of the Potomac. Edited by Lawrence Frederick Kohl. Chicago: La Monte, O’Donnell Printers, 1893.

Daly, Maria Lydig. Diary of a Union Lady, 1861-1865. Edited by Harold Earl Hammond. New York: Funk and Wagnalls Company, Inc., 1962; reprint, Lincoln: University of Nebraska Press, 2000.

Douglass, Frederick. Life and Times of Frederick Douglass. Edited by Henry Louis Gates Jr. New York: Pathway Press, Inc., 1941.

Ellis, Thomas T. Leaves from the Diary of an Army Surgeon: Or, Incidents of Field, Camp, and Hospital Life. New York: John Bradburn, 1863.

Emerson, Sarah Hopper. ed. Life of Abby Hopper Gibbons: Told Chiefly through Her Correspondence. New York: G. P. Putnam's Sons, 1897.

Favill, Josiah Marshall. The Diary of a Young Officer Serving with the Armies of the United States during the War of the Rebellion. Chicago: R. R. Donnelley \& Sons Company, 1909.

Gancas, Ron, ed. Dear Teres: The Civil War Letters of Andrew Joseph Duff and Dennis Dugan of Company F, the Pennsylvania Seventy-Eighth Infantry. Chicora, PA: Mechling Bookbindery, 1999.

Garrison, William Lloyd. The Letters of William Lloyd Garrison: No Union with the Slaveholders, 1841-1849. Vol. 3. Edited by Walter McIntosh Merrill. Cambridge, MA: The Belknap Press of Harvard University Press, 1973.

Higginson, Thomas Wentworth. Massachusetts in the Army and Navy During the War of 18611865. Vol. 1. Boston: Wright \& Potter, 1895-1896.

Leech, Arthur Blennerhassett. Irish Riflemen in America. London: Edward Stanford, 1875.

Lincoln, Abraham. The Collected Works of Abraham Lincoln. Vol. 5. Edited by Roy P. Basler. New Brunswick, NJ: Rutgers U.P., 1953-1955.

MacNamara, Daniel George. The History of the Ninth Regiment, Massachusetts Volunteers Infantry, Second Brigade, First Division, Fifth Army Corps, Army of the Potomac, June 1861-June 1864. Boston: E. B. Stillings \& Co., Printers, 1899.

MacNamara, M. H. The Irish Ninth in Bivouac \& Battle, or Virginia and Maryland Campaigns. Boston: Lee and Shepherd, 1867. 
McCarter, William. My Life in the Irish Brigade: The Civil War Memoirs of Private William Mccarter, 116th Pennsylvania Infantry. Edited by Kevin O’Brien. Cambridge, MA: De Capo Press, 1996.

McDermott, Anthony W. A Brief History of the 69th Regiment Pennsylvania Veteran Volunteers, from Its Formation until Final Muster Out of the United States Service. Philadelphia: PA: D. J. Gallagher \& Co., 1889.

Monk, Maria. Awful Disclosures of the Hotel Dieu Nunnery. 1836, reprint Hamden, CT: Archon Books, 1962.

Morse, Samuel F. B. Foreign Conspiracy Against the Liberties of the United States. New York: Van Nostrand \& Dwight, 1836.

O'Connell, Daniel. Daniel O'Connell Upon American Slavery: With Other Irish Testimonies. New York: Published by the American Anti-Slavery Society, 1860.

Osborne, William H. The History of the Twenty-ninth Regiment of Massachusetts Volunteer Infantry in the Late War of the Rebellion. Boston: A. J. Wright, 1877.

Proceedings of the Second National Congress of the Fenian Brotherhood, Held in Cincinnati, Ohio, January 1865. Philadelphia: J. Gibbons, 1865.

Reed, Rebecca. Six Months in a Convent: The Narrative of Rebecca Theresa Reed. Boston, MA: Russell, Odiorne \& Metcalf, 1835.

Seymour, Horatio. Public Record: Including Speeches, Messages, Proclamations, Official Correspondence, and Other Public Utterances of Horatio Seymour from the Campaign of 1856 to the Present Time. Edited by Thomas M. Cook and Thomas W. Knox. New York: I. W. England, 1868.

Shaw, Robert Gould. Blue-Eyed Child of Fortune: The Civil War Letters of Colonel Robert Gould Shaw. Edited by Russell Duncan. Athens, GA: University of Georgia Press, 1992.

Strong, George Templeton. Diary of the Civil War, 1860-1865. Edited by Allan Nevins. New York: The Macmillan Company, 1962.

Third Annual Report of the State Historian of the State of New York, 1897. New York: Wynkoop Hallenbeck Crawford Company, 1898.

de Trobriand, Régis. Four Years with the Army of the Potomac. Boston: Tichnor and Company, 1899.

Walker, Francis Amasa. History of the Second Army Corps in the Army of the Potomac. New York: C. Scribner's Sons, 1886. 
Welsh, Peter. Irish Green and Union Blue: The Civil War Letters of Peter Welsh, Color Sergeant, 28th Regiment, Massachusetts Volunteers. Edited by Lawrence Frederick Kohl and Margaret Cossé Richard. New York: Fordham University Press, 1986.

White, John. Sketches from America. London: Sampson, Low, Son, and Marston, 1870.

Journals and Newspapers:

Boston Pilot

Daily National Intelligencer

Harper's Weekly (New York)

Irish World (New York)

Liberator (Boston)

Metropolitan Record

Metropolitan Record and New York Vindicator

New York Herald

New York Irish American

New York Observer

New York Times

New York World

Southern Citizen

The Army and Navy Journal

Online Sources:

1860 United States Federal Census. Digital Images. ancestry.com. http://www.ancestry.com.

“Civil War Widow's Pension Records.” Digital Images. Fold3. http://www.fold3.com.

Dan Dillon, 10th Illinois Cavalry

John Doherty, 63rd New York Infantry

William Dwyer, 63rd New York Infantry

Farrell Hogg, 88th New York Infantry

Patrick McCaffrey, 69th New York Infantry

William McIntyre, 95th Pennsylvania Infantry

Felix Mooney, 61st New York Infantry

Charles Trainor, 69th New York Infantry

James Welsh, 82nd Pennsylvania Infantry

"Dependent Mother's Pension File." Digital Images. Fold3. http://www.fold3.com.

John Gannon, 26th New York Infantry

Fulton, Julia. “The Civil War Letters of Patrick H. Sloan.” JuliaFulton.com.

http://juliafulton.com/phsloan/patsloan.htm.

"New York Muster Roll Abstracts." Digital Images. ancestry.com. http://www.ancestry.com. 


\section{Secondary Sources:}

Books:

Anbinder, Tyler. Nativism and Slavery: The Northern Know-Nothings and the Politics of the 1850s. New York: Oxford University Press, 1992.

Andrews, J. Cutler. The North Reports the Civil War. Pittsburgh: University of Pittsburgh Press, 1955.

Athearn, Robert G. Thomas Francis Meagher: An Irish Revolutionary in America. New York: Arno Press, 1976.

Barnes, James J., and Patience P. Barnes. The American Civil War Through British Eyes: Dispatches from British Diplomats, Volume 3, February 1863-December 1865. Kent, $\mathrm{OH}$ : Kent State University Press, 2005.

Bernstein, Iver. The New York City Draft Riots: Their Significance for American Society and Politics in the Age of the Civil War. New York: Oxford University Press, 1990.

Bilby, Joseph G. Remember Fontenoy!: The 69th New York and the Irish Brigade in the Civil War. Hightstown, NJ: Longstreet House, 1995.

Billington, Ray Allen. The Protestant Crusade, 1800-1860: A Study of the Origins of American Nativism. New York: Macmillan, 1938.

Bruce, Susannah Ural. The Harp and the Eagle: Irish-American Volunteers and the Union Army, 1861-1865. New York: New York University Press, 2006.

Burton, Brian K. The Peninsula and Seven Days: A Battlefield Guide. Lincoln, NE: University of Nebraska Press, 2007.

Burton, William L. Melting Pot Soldiers: The Union's Ethnic Regiments. New York: Fordham University Press, 1998.

Clark, Dennis. The Irish in Philadelphia: The Generations of Urban Experience. Philadelphia: Temple University Press, 1973; reprint, Philadelphia: Temple University Press, 1984.

Coffman, Edward M. The Old Army: A Portrait of the American Army in Peacetime, 1784-1898. New York: Oxford University Press, 1986.

Cook, Adrian. The Armies in the Streets: The New York City Draft Riots of 1863. Lexington: The University Press of Kentucky, 1974.

Diner, Hasia R. Erin's Daughters in America: Irish Immigrant Women in the Nineteenth Century. Baltimore: Johns Hopkins University Press, 1983. 
Dolan, Jay P. The Immigrant Church: New York's Irish and German Catholics, 1815-1865. Baltimore: Johns Hopkins University Press, 1975.

Doyle, Frank A. A Party of Mad Fellows: The Story of the Irish Regiments in the Army of the Potomac. Dayton, OH: Morningside Books, 1996.

Dudden, Faye E. Serving Women: Household Service in Nineteenth Century America. Middletown, CT: Wesleyan University Press, 1983.

Ernst, Robert. Immigrant Life in New York City, 1825-1863. New York: King's Crown Press, 1949.

Fleche, Andre. The Revolutions of 1861: The American Civil War in the Age of Nationalist Conflict. Chapel Hill: University of North Carolina Press, 2012.

Fox, William F. Regimental Losses in the American Civil War. Albany, NY: Albany Publishing, 1889.

Gallagher, Gary W. The Richmond Campaign of 1862: The Peninsula and the Seven Days. Chapel Hill: University of North Carolina Press, 2000.

Gleeson, David T. The Green and the Grey: The Irish in the Confederate States of America. Chapel Hill, NC: The University of North Carolina Press, 2013.

Gordon, Michael A. The Orange Riots: Irish Political Violence in New York City, 1870-1871. New York: Cornell University Press, 1993.

Gottfried, Bradley M. The Maps of Antietam: An Atlas of the Antietam (Sharpsburg) Campaign, Including the Battle of South Mountain, September 2-20, 1862. El Dorado Hills, CA: Savas Beatie LLC, 2012.

Hamilton, Thomas. Men and Manners in America. Philadelphia, PA: Carey, Lea \& Blanchard, 1833.

Hennessy, John J. The First Battle of Manassas: An End to Innocence, July 18-21,1861, rev. ed. Mechanicsburg, PA: Stackpole Books, 2015.

Hueston, Robert Francis. The Catholic Press and Nativism, 1840-1860. New York: Arno Press, 1976.

Ignatiev, Noel. How the Irish Became White. New York: Routledge, 1995.

Jacoby, George Paul. Catholic Child Care in Nineteenth Century New York: With a Correlated Summary of Public and Protestant Child Welfare. Washington, D.C.: The Catholic University of American Press, 1941. 
Jenkins, Brian. Fenians and Anglo-American Relations during Reconstruction. Ithaca, NY: Cornell University Press, 1969.

Joyce, William L. Editors and Ethnicity: A History of the Irish-American Press, 1848-1883. New York: Arno Press, 1976.

Keating, Ryan W. Shades of Green: Irish Regiments, American Soldiers, and Local Communities in the Civil War Era. New York: Fordham University Press, 2017.

Kenneally, James J. The History of American Catholic Women. New York: Crossroad Publishing Company, 1990.

Kenny, Kevin. The American Irish: A History. New York: Longman, 2000.

— — - Ireland and the British Empire. New York: Oxford University Press, 2004.

Klein, Christopher. When the Irish Invaded Canada: The Incredible True Story of the Civil War Veterans Who Fought for Ireland's Freedom. New York: Anchor Books, 2019.

Kleppner, Paul. The Third Electoral System, 1853-1892: Parties, Voters, and Political Cultures. Chapel Hill: The University of North Carolina Press, 1979.

Knobel, Dale T. "America for the Americans:" The Nativist Movement in the United States. New York: Twayne Publishers, 1996.

Kurtz, William B. Excommunicated from the Union: How the Civil War Created a Separate Catholic America. New York: Fordham University Press, 2016.

Lebow, Richard N. White Britain and Black Ireland: The Influence of Stereotypes on Colonial Policy. Philadelphia: Institute for the Study of Human Issues, 1976.

Lengel, Edward G. Irish through British Eyes: Perceptions of Ireland in the Famine Era. Westport, CT: Praeger, 2002.

Lonn, Ella. Foreigners in the Union Army and Navy. Baton Rouge: Louisiana State University Press, 1951.

Loughery, John. Dagger John: Archbishop John Hughes and the Making of Irish America. Ithaca, NY: Cornell University Press, 2018.

Luskey, Brian P. Men is Cheap: Exposing the Frauds of Free Labor in Civil War America. Chapel Hill: The University of North Carolina Press, 2020.

Manning, Chandra. What This Cruel War Was Over: Soldiers, Slavery, and the Civil War. New York: Alfred A. Knopf, 2007. 
McCaffrey, Lawrence J. The Irish Catholic Diaspora in America. Washington, D.C.: Catholic University of America Press, 1997.

McConnell, Stuart Charles. Glorious Contentment: The Grand Army of the Republic, 1865-1900. Chapel Hill: University of North Carolina Press, 1992.

McDaniel, W. Caleb. The Problem of Democracy in the Age of Slavery: Garrisonian Abolitionists and Transatlantic Reform. Baton Rouge: Louisiana State University Press, 2013.

McGovern, Bryan P. John Mitchel: Irish Nationalist, Southern Secessionist. Knoxville: The University of Tennessee Press, 2009.

McMahon, Cian T. The Global Dimensions of Irish Identity: Race Nation, and the Popular Press, 1840-1880. Chapel Hill, NC: University of North Carolina Press, 2015.

McPherson, James M. Battle Cry of Freedom: The Civil War Era. New York: Oxford University Press, 1988.

— _ - For Cause and Comrades: Why Men Fought in the Civil War. New York: Oxford University Press, 1997.

_ _ - Ordeal by Fire: The Civil War and Reconstruction. 3rd ed. New York: McGraw-Hill, 2001.

Miller, Kerby A. Emigrants and Exiles: Ireland and the Irish Exodus to North America. New York: Oxford University Press, 1985.

Mitchell, Reid. The Vacant Chair: The Northern Soldier Leaves Home. New York: Oxford University Press, 1995.

Morris, Charles R. American Catholic: The Saints and Sinners Who Built America's Most Powerful Church. New York: Vintage Books, 1997.

Murdock, Eugene C. One Million Men: The Civil War Draft in the North. Madison, WI: The State Historical Society of Wisconsin Madison, 1971.

Murphy, Angela F. American Slavery, Irish Freedom: Abolition, Immigrant Citizenship, and the Transatlantic Movement for Irish Repeal. Baton Rouge: Louisiana State University Press, 2010.

O’Connor, Thomas H. The Boston Irish: A Political History. Boston: Back Bay Books, 1995.

O'Reilly, Francis Augustín. The Fredericksburg Campaign: Winter War on the Rappahannock. Baton Rouge: Louisiana State University Press, 2003. 
Roediger, David R. The Wages of Whiteness: Race and the Making of the American Working Class. London: Verso, 2007.

Rosenwaike, Ira. Population History of New York City. Syracuse, NY: Syracuse University Press, 1972.

Samito, Christian. Becoming American Under Fire: Irish Americans, African Americans, and the Politics of Citizenship during the Civil War Era. Ithaca, NY: Cornell University Press, 2009.

Sears, Stephen W. Landscape Turned Red: The Battle of Antietam. New Haven, CT: Ticknor \& Fields, 1983

_ _ - To the Gates of Richmond: The Peninsula Campaign. New York: Ticknor \& Fields, 1992.

Senior, Hereward. The Last Invasion of Canada: The Fenian Raids, 1866-1870. Toronto:

Dundurn Press, 1991.

Shattuck, Gardiner H. A Shield and Hiding Place: The Religious Life of the Civil War Armies. Macon, GA: Mercer University Press, 1987.

Shaw, Richard. Dagger John: The Unquiet Life and Times of Archbishop John Hughes of New York. New York: Paulist Press, 1977.

Shultz, Jane. Women at the Front: Hospital Workers in Civil War America. Chapel Hill: University of North Carolina Press, 2004.

Stansell, Christine. City of Women: Sex and Class in New York, 1789-1860. New York: Knopf, 1986.

Warner, Ezra J. Generals in Blue: Lives of the Union Commanders. Baton Rouge: Louisiana State University Press, 1964.

Waugh, John C. Reelecting Lincoln: The Battle for the 1864 Presidency. New York: Crown Publishers, Inc., 1997.

White, Jonathan W. Emancipation, The Union Army, and the Reelection of Abraham Lincoln. Baton Rouge: Louisiana State University Press, 2014.

Wiley, Bell Irvin. The Life of Billy Yank: The Common Solider of the Union. Indianapolis, IN: Bobbs-Merrill, 1952.

Articles and Chapters: 
Adams, Bluford. "New Ireland: The Place of Immigrants in American Regionalism," Journal of American Ethnic History 24, no. 2 (Winter 2005): 3-33.

Anbinder, Tyler. "Which Poor Man's Fight? Immigrants and the Federal Conscription of 1863." Civil War History 52, no. 4 (December 2006): 344-372.

Bhromeil, Una Ni. "The Gaelic Movement in the United States, 1870-1915." New Hibernia Review 5, no. 3 (Autumn 2001): 87-100.

Brubaker, Rogers and Frederick Cooper. "Beyond 'Identity." Theory and Society 29, no. 1 (February 2000): 1-47.

Diner, Hasia R. “'The Most Irish City in the Union:' The Era of the Great Migration, 18441877." In The New York Irish. Edited by Ronald H. Bayor and Timothy J. Meagher. Baltimore: The Johns Hopkins University Press, 1996.

Erikson, Paul. "New Books, New Men: City-Mysteries Fiction, Authorship, and the Literary Market.” Early American Studies 1, no. 1 (Spring 2003): 273-312.

George, Joseph Jr. “'A Catholic Family Newspaper' Views the Lincoln Administration: John Nullaly’s Copperhead Weekly.” Civil War History 24, No. 2 (June 1978): 112-132.

Hodges, Graham. “'Desirable Companions and Lovers:' Irish American and African Americans in the Sixth Ward, 1830-1870." In The New York Irish. Edited by Ronald H. Bayor and Timothy J. Meagher. Baltimore: The Johns Hopkins University Press, 1996.

Levine, Peter. "Draft Evasion in the North during the Civil War, 1863-1865." The Journal of American History 67, no. 4 (March 1981): 816-834.

Marshall, Nicholas. "The Rural Newspaper and the Circulation of Information and Culture in New York and the Antebellum North." New York History 88, no. 2 (Spring 2007): 133151.

McCaffrey, Lawrence J. "Forgoing Forward and Looking Back." In The New York Irish. Edited by Ronald H. Bayor and Timothy J. Meagher. Baltimore, MD: Johns Hopkins University Press, 1996.

Miller, Randall M. "Catholic Religion, Irish Ethnicity, and the Civil War." In Religion and the American Civil War. Edited by Randall M. Miller, Harry S. Stout, and Charles Reagan Wilson. New York: Oxford University Press, 1998.

Spann, Edward K. "Union Green: The Irish Community in the Civil War.” In The New York Irish. Edited by Ronald H. Bayor and Timothy J. Meagher. Baltimore: The Johns Hopkins University Press, 1996. 
Winther, Oscar Osburn. "The Soldier Vote in the Election of 1864." New York History 25, no. 4 (October, 1944): 440-458.

Yoder, Don. "The Pennsylvania Germans: Three Centuries of Identity Crisis." In America and the Germans: An Assessment of a Three-Hundred-Year History. Edited by Frank and Joseph McVeigh. Vol. 1. Philadelphia: University of Pennsylvania Press, 1985. 